U.S. Department of the Interior

U.S. Geological Survey

(200)

WRi

no. $2000=4168$

c.l

Water-Budget Estimates for the 14 Hydrographic Areas in the Middle Humboldt River Basin, North-Central Nevada

Water-Resources Investigations Report 00-4168

Prepared in cooperation with the

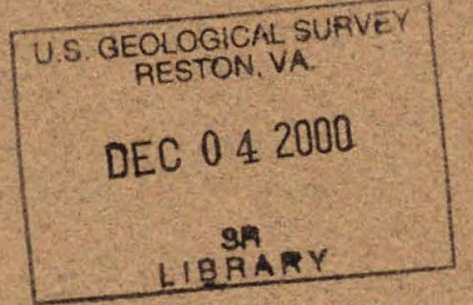

NEVADA DIVISION OF WATER RESOURCES

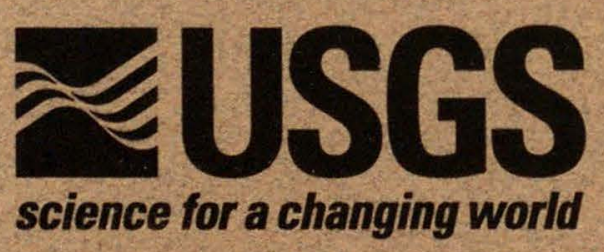




\title{
Water Budget Estimates for the 14 Hydrographic Areas in the Middle Humboldt River Basin, North-Central Nevada
}

\author{
By David L. Berger
}

U.S. GEOLOGICAL SURVEY

Water-Resources Investigations Report 00-4168

Prepared in cooperation with the

NEVADA DIVISION OF WATER RESOURCES

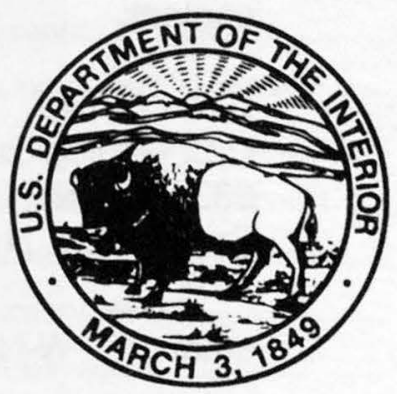

Carson City, Nevada 2000 


\title{
U.S. DEPARTMENT OF THE INTERIOR BRUCE BABBITT, Secretary
}

\author{
U.S. GEOLOGICAL SURVEY \\ CHARLES G. GROAT, Director
}

Any use of trade, product, or firm names in this publication is for descriptive

purposes only and does not imply endorsement by the U.S. Government

For additional information

contact:

District Chief

U.S. Geological Survey

333 West Nye Lane, Room 203

Carson City, NV 89706-0866

email: GS-W-NVpublic-info@usgs.gov

http://nevada.usgs.gov
Copies of this report can be purchased from:

U.S. Geological Survey

Information Services

Building 810

Box 25286, Federal Center

Denver, CO 80225-0286 


\section{CONTENTS}

Abstract

Introduction.

Background

Purpose and Scope

Location and General Features of Study Area.

Previous Investigations

Development of Annual Water Budgets.

Conceptualization of a Hydrologic System

Summary of Methods for Estimating Water-Budget Components .

Discussion of Water-Budget Estimates

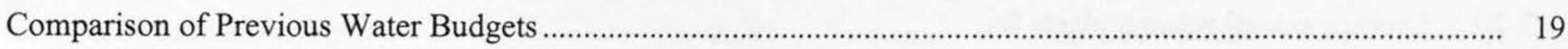

Summary and Conclusions

Glossary

References Cited.

\section{FIGURES}

1. Map showing locations of middle Humboldt River Basin and the 14 hydrographic areas, north-central Nevada

2. Schematic cross sections of typical basins, showing landforms and general patterns of ground-water movement, middle Humboldt River Basin, north-central Nevada.

3. Schematic diagram showing interrelations among water-budget components and landforms for simplified hydrologic-flow system, middle Humboldt River Basin, north-central Nevada

4-17. Maps showing distribution of precipitation and landforms in:

4. Pine Valley Hydrographic Area, middle Humboldt River Basin, north-central Nevada

5. Crescent Valley Hydrographic Area, middle Humboldt River Basin, north-central Nevada

6. Carico Lake Valley Hydrographic Area, middle Humboldt River Basin, north-central Nevada .....

7. Upper Reese River Valley Hydrographic Area, middle Humboldt River Basin, north-central Nevada

8. Antelope Valley Hydrographic Area, middle Humboldt River Basin, north-central Nevada

9. Middle Reese River Valley Hydrographic Area, middle Humboldt River Basin, north-central Nevada

10. Lower Reese River Valley Hydrographic Area, middle Humboldt River Basin, north-central Nevada

11. Whirlwind Valley Hydrographic Area, middle Humboldt River Basin, north-central Nevada

12. Boulder Flat Hydrographic Area, middle Humboldt River Basin, north-central Nevada

13. Rock Creek Valley Hydrographic Area, middle Humboldt River Basin, north-central Nevada

14. Willow Creek Valley Hydrographic Area, middle Humboldt River Basin, north-central Nevada

15. Clovers Area, middle Humboldt River Basin, north-central Nevada.

16. Pumpernickel Valley Hydrographic Area, middle Humboldt River Basin, north-central Nevada .

17. Kelly Creek Area, middle Humboldt River Basin, north-central Nevada.

18. Graph showing relations between inflow and outflow 


\section{TABLES}

1. Hydrographic areas in middle Humboldt River Basin, north-central Nevada.

2. Equations of hydrologic equilibrium for average annual water budgets for landforms and a typical basin in middle Humboldt River Basin, north-central Nevada

3. Area of landforms and distribution of simulated average annual precipitation on landforms in the 14 hydrographic areas of middle Humboldt River Basin, north-central Nevada..

4. Simulated average annual precipitation and estimated average annual runoff, water yield, subsurface flow, and evapotranspiration in mountain-block areas in the 14 hydrographic areas of middle Humboldt River Basin, north-central Nevada

5. Estimated average annual runoff, evapotranspiration, and subsurface flow from piedmont-slope areas in the 14 hydrographic areas of middle Humboldt River Basin, north-central Nevada

6. Average annual evapotranspiration rates from areas of bare soil or phreatophyte vegetation, evaporation rates from open water, and annual volume of ground-water evapotranspiration from valley lowlands, 1989 and 1995, in the 14 hydrographic areas of middle Humboldt River Basin, north-central Nevada.

7-20. Average annual water budgets for:

7. Pine Valley Hydrographic Area, middle Humboldt River Basin, north-central Nevada. 21

8. Crescent Valley Hydrographic Area, middle Humboldt River Basin, north-central Nevada.

9. Carico Lake Valley Hydrographic Area, middle Humboldt River Basin, north-central Nevada

10. Upper Reese River Valley Hydrographic Area, middle Humboldt River Basin, north-central Nevada ........ 24

11. Antelope Valley Hydrographic Area, middle Humboldt River Basin, north-central Nevada ....................... 25

12. Middle Reese River Valley Hydrographic Area, middle Humboldt River Basin, north-central Nevada....... 26

13. Lower Reese River Valley Hydrographic Area, middle Humboldt River Basin, north-central Nevada....... 27

14. Whirlwind Valley Hydrographic Area, middle Humboldt River Basin, north-central Nevada ................... 28

15. Boulder Flat Hydrographic Area, middle Humboldt River Basin, north-central Nevada ............................ 29

16. Rock Creek Valley Hydrographic Area, middle Humboldt River Basin, north-central Nevada.................. 30

17. Willow Creek Valley Hydrographic Area, middle Humboldt River Basin, north-central Nevada .............. 31

18. Clovers Area, middle Humboldt River Basin, north-central Nevada ........................................................ 32

19. Pumpernickel Valley Hydrographic Area, middle Humboldt River Basin, north-central Nevada ............... 33

20. Kelly Creek Area, middle Humboldt River Basin, north-central Nevada .................................................... 34

21. Estimated average annual ground-water budgets for the 14 hydrographic areas, middle Humboldt River

Basin, north-central Nevada 


\section{CONVERSION FACTORS and VERTICAL DATUM}

\begin{tabular}{rcl}
\hline Multiply & By & To obtain \\
\hline acre & 4,047 & square meter \\
acre-foot (acre-ft) & 0.001233 & cubic hectometer \\
cubic hectometer per year \\
acre-foot per year (acre-ft/yr) & 0.001233 & cubic meter per second \\
cubic foot per second $\left(\mathrm{ft}^{3} / \mathrm{s}\right)$ & 0.02832 & meter \\
foot $(\mathrm{ft})$ & 0.3048 & meter per day \\
foot per day $(\mathrm{ft} / \mathrm{d})$ & 0.3048 & meter per meter \\
foot per foot $(\mathrm{ft} / \mathrm{ft})$ & 1 & meter per year \\
foot per year $(\mathrm{ft} / \mathrm{yr})$ & 0.3048 & millimeter \\
inch $(\mathrm{in})$. & 25.4 & millimeter per year \\
inch per year $(\mathrm{in} / \mathrm{yr})$ & 25.4 & kilometer \\
mile $(\mathrm{mi})$ & 1.609 & square meter \\
square foot $\left(\mathrm{ft}^{2}\right)$ & 0.09290 & square kilometer \\
square mile $\left(\mathrm{mi}{ }^{2}\right)$ & 2.590 &
\end{tabular}

Sea level: In this report, "sea level" refers to the National Geodetic Vertical Datum of 1929 (NGVD of 1929, formerly called "Sea-Level Datum of 1929"), which is derived from a general adjustment of the first-order leveling networks of the United States and Canada. 


\section{Water-Budget Estimates for the 14 Hydrographic Areas in the Middle Humboldt River Basin, North-Central Nevada}

\author{
by David L. Berger
}

\section{ABSTRACT}

Water budgets were developed for the 14 hydrographic areas in the middle Humboldt River Basin of north-central Nevada. The water budgets include estimates of average annual precipitation, runoff, water yield, ground-water recharge and subsurface flow, and evapotranspiration (ET) determined from recently developed or revised methods. Ground-water pumping is not included in the budget estimates. The estimated budgets represent average annual volumes over a 30 -year reference period (1961-90) and are compared to water budgets developed more than 30 years ago.

Annual inflow to the middle Humboldt River basin is about 5 million acre-feet. An estimated 4.6 million is from precipitation in the 14 hydrographic areas and about 350,000 acre-feet is inflow from the Humboldt River. Annual outflow is about 5.1 million acre-feet, of which ET accounts for 4.8 million acre-feet, and outflow of the Humboldt River is about 300,000 acre-feet.

Average annual precipitation in the hydrographic areas for 1961-90 ranged from 105 to 128 percent of that for the 1912-63 period. The annual volume of ET in the 14 areas was 102 to almost 134 percent of that previously estimated, although the percentage of annual precipitation lost to ET is similar. About 15 percent of the annual precipitation in mountain-block areas becomes water yield (either ground water or runoff) as compared to previous estimates of 11 percent. On the basis of mass-balance calculations, ground-water recharge on average is about 145 percent of previous estimates.

\section{INTRODUCTION}

The Humboldt River Basin (fig. 1), in north-central Nevada, is the only major river basin whose drainage area lies entirely within the State. The area of the Humboldt River Basin covers $16,900 \mathrm{mi}^{2}$ and encompasses about 15 percent of the State. Precipitation is the principal source of all the water that flows in the basin. Traditional water users in the basin rely heavily on surface water and to a lesser extent on ground water. However, ground-water withdrawals in the basin have increased over the last 10 to 15 years, mostly as a result of the development of large open-pit gold mines.

\section{Background}

In 1995, the U.S. Geological Survey (USGS), in cooperation with the Nevada Department of Conservation and Natural Resources, began the Humboldt River Basin Assessment. The overall objectives of the assessment are to (1) provide scientific appraisals of surfacewater and ground-water resources of each hydrographic area in the Humboldt River Basin, (2) determine the interactions between surface water and ground water among contributing areas and the main stem of the Humboldt River, and (3) determine the effects of all major water uses in the basin on the quantity, quality, and beneficial use of the basin's water resources. The assessment has focused on the middle Humboldt River Basin, which consists of 14 hydrographic areas ${ }^{1}$ and includes large land areas irrigated for agriculture as well as most of the large mining operations in northern Nevada. In general, the middle Humboldt River Basin is defined by the hydrographic areas that are tributary to the Humboldt River from about 10 mi downstream from Carlin to about $5 \mathrm{mi}$ upstream from Golconda (fig. 1).

\footnotetext{
${ }^{1}$ Formal hydrographic areas in Nevada were delineated systematically by the USGS and Nevada Division of Water Resources in the late 1960 's for scientific and administrative purposes (Cardinalli and others, 1968; Rush, 1968). The official hydrographic-area names, numbers, and geographic boundaries continue to be used in USGS scientific reports and Division of Water Resources administrative activities.
} 

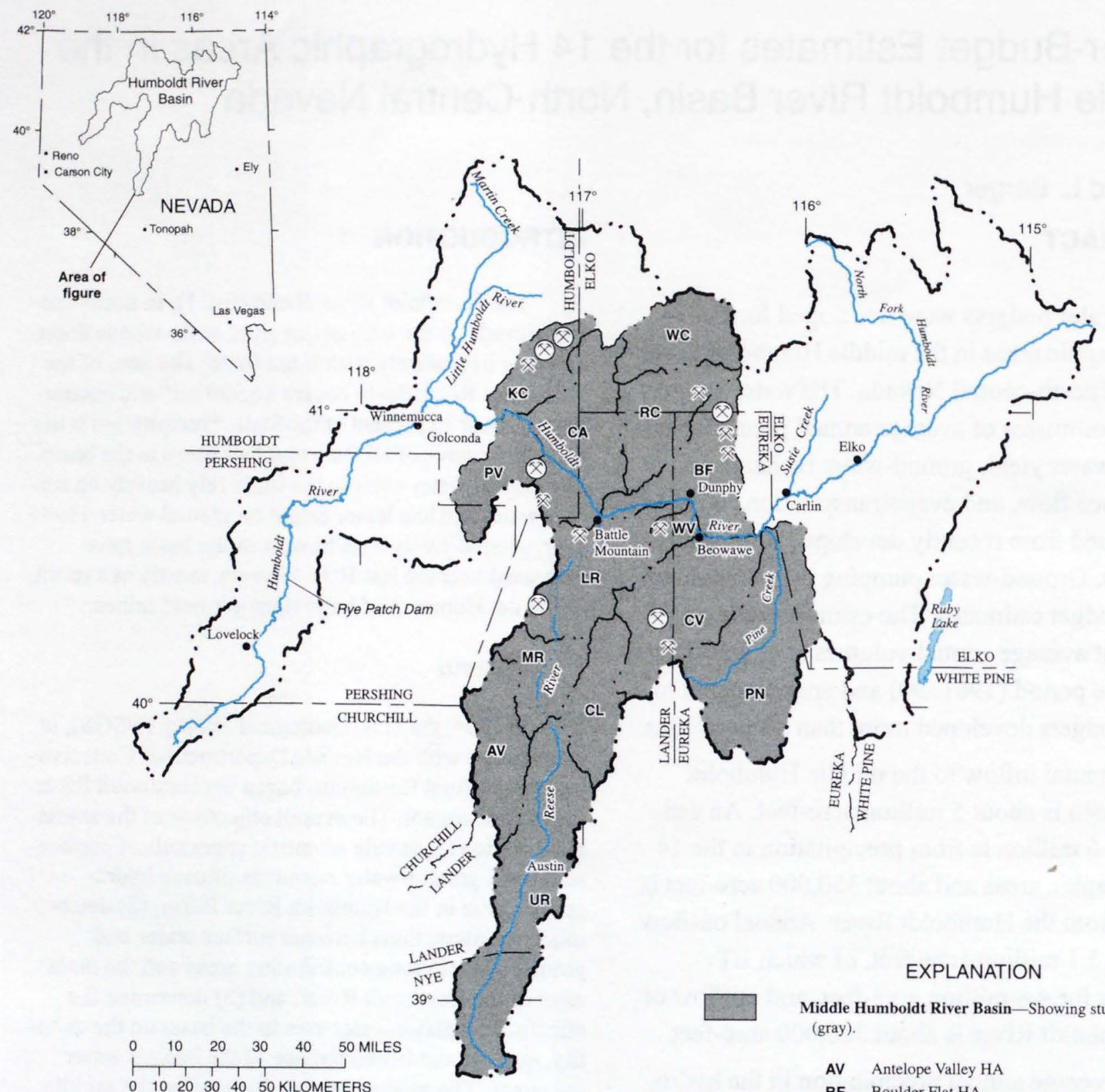

\section{EXPLANATION}

Middle Humboldt River Basin-Showing study area (gray).

$\begin{array}{ll}\text { AV } & \text { Antelope Valley HA } \\ \text { BF } & \text { Boulder Flat HA } \\ \text { CA } & \text { Clovers Area } \\ \text { CL } & \text { Carico Lake Valley HA } \\ \text { CV } & \text { Crescent Valley HA } \\ \text { KC } & \text { Kelly Creek Area } \\ \text { LR } & \text { Lower Reese River Valley HA } \\ \text { MR } & \text { Middle Reese River Valley HA } \\ \text { PN } & \text { Pine Valley HA } \\ \text { PV } & \text { Pumpernickel Valley HA } \\ \text { RC } & \text { Rock Creek Valley HA } \\ \text { UR } & \text { Upper Reese River Valley HA } \\ \text { WC } & \text { Willow Creek Valley HA } \\ \text { WV } & \text { Whirlwind Valley HA }\end{array}$

Base from U.S. Geological Survey digital data, 1:100,000, 1977-88; 1:24,000, 1969-90 Universal Transverse Mercator projection

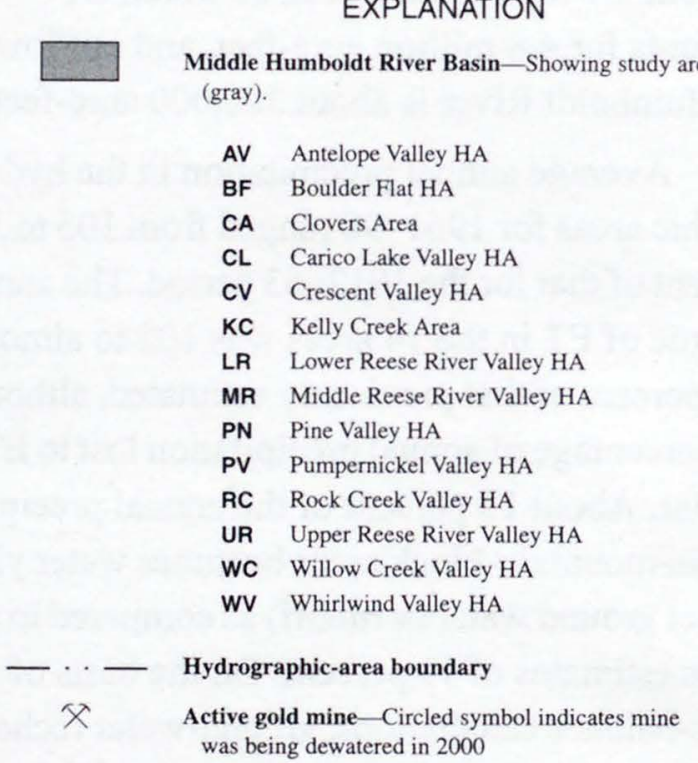

Figure 1. Locations of middle Humboldt River Basin and the 14 hydrographic areas, north-central Nevada. 
The Humboldt River Basin Assessment was planned as a series of phases. Activities of phase 1 (completed in September 1998) were to (1) make hydrologic data for the Humboldt River Basin more easily accessible by publishing it on the web site, which has the URL < http://nevada.usgs.gov/humb>, (2) define the hydrogeologic framework and shallow ground-water conditions in the middle Humboldt River Basin, (3) quantify ground-water withdrawals for agriculture, generation of electricity, industrial use, mining, and municipal use in the middle Humboldt River Basin, and (4) develop and revise methods for estimating water-budget components. Activities for phase 2, which began in October 1998, are to (1) continue quantifying ground-water withdrawals in the middle Humboldt River Basin, (2) estimate water budgets for the 14 hydrographic areas in the middle Humboldt River Basin by methods developed in phase 1 and (3) develop a numerical model to simulate effects of water use and climate variability on the water resources of the middle Humboldt River Basin.

\section{Purpose and Scope}

The purpose of this report is to present estimated average annual water budgets for the 14 hydrographic areas within the middle Humboldt River Basin. The report describes the results of applying a systematic approach for estimating water budgets for individual hydrographic areas by recently developed or revised methods (Berger, 2000). The water budgets include estimates of precipitation, runoff, water yield, groundwater recharge and subsurface flow, and evapotranspiration that represent average annual volumes over a 30-yr reference period, 1961-90. The report also describes the relative distribution and movement of water among the major landforms within each hydrographic area. Budget estimates derived from this study are compared briefly to those developed in earlier studies (Zones, 1961; Crosthwaite, 1963; Eakin and others, 1965; Rush and others, 1971; Olmsted and Rush, 1987; Maurer and others, 1996).

\section{Location and General Features of Study Area}

The areal extent of the middle Humboldt River Basin, which is in north-central Nevada, is nearly 7,500 $\mathrm{mi}^{2}$ (fig. 1). The drainage basin is characterized by northwest-trending mountain ranges separated by broad alluvial valleys. Altitudes within the basin range from about 4,350 $\mathrm{ft}$, where the Humboldt River leaves the basin near Golconda, to almost $11,800 \mathrm{ft}$, in the Toiyabe Range south of Austin (fig. 1). The basin is sparsely populated and includes portions of Pershing, Humboldt, Lander, Eureka, Nye, and Elko Counties.

The geology of north-central Nevada is complex and is the major control on water movement through the hydrologic systems within the area. Consolidated rock ranging in age from Precambrian to late Tertiary makes up the mountainous regions. The intervening valleys are filled with unconsolidated deposits of Tertiary and Quaternary age that commonly are several thousand feet thick. The hydrogeologic framework of the Humboldt River Basin was summarized by Plume and Carlton (1988), Plume (1996), and Plume and Ponce (1999).

The climate of the study area is arid in the valleys to subhumid in the mountains and is characterized by hot summers and cold winters. Average annual precipitation over the 30-yr reference period (1961-90) is commonly less than 10 in. on the valley floors and as much as 30 in. at the higher altitudes in the mountains (Owenby and Ezell, 1992). Because of the large range in annual precipitation between valley floors and surrounding mountains, the vegetation in north-central Nevada is diverse.

Each of the 14 hydrographic areas that make up the middle Humboldt River Basin (fig. 1 and table 1) is a single topographic basin. The boundaries of the hydrographic areas, initially delineated by Cardinalli and others (1968) and Rush (1968), were refined further by using topographic-drainage boundaries interpreted from 1:24,000-scale maps. Of the 14 hydrographic areas, 9 are south of the Humboldt River: Pine Valley, Carico Lake Valley, Crescent Valley, Whirlwind Valley, Upper Reese River Valley, Antelope Valley, Middle Reese River Valley, Lower Reese River Valley, and Pumpernickel Valley (fig. 1). These 
nine areas south of the river appear to function as separate ground-water systems, although four are hydraulically connected by streamflow and subsurface flow. Boulder Flat, Willow Creek Valley, Rock Creek Valley, the Clovers Area, and the Kelly Creek Area are north of the Humboldt River (fig. 1 and table 1). These five areas appear to function as a single, extensive ground-water flow system in which ground-water divides do not coincide with topographic divides (Maurer and others, 1996; Plume and Ponce, 1999). The Humboldt River and its associated flood plain hereafter is referred to as the Humboldt River valley. This valley comprises the seven hydrographic areas, Boulder Flat, Crescent Valley, Whirlwind Valley, Lower Reese River Valley, Clovers Area, Pumpernickel Valley, and Kelly Creek Area.

\section{Previous Investigations}

In 1959, the Nevada State Legislature authorized the Humboldt River Research Project (Statutes, Chapter 97, 1959). The purposes of the project, in part, were to identify available hydrologic data and information for the Humboldt River Basin, quantitatively describe the hydrologic processes in the basin, and develop techniques needed to evaluate the water resources of the Humboldt River Basin. Information from the period 1912-63 was used to analyze the hydrologic conditions

Table 1. Hydrographic areas in middle Humboldt River Basin, north-central Nevada

\begin{tabular}{clc}
\hline Figure 1 & \multicolumn{1}{c}{ Name } & $\begin{array}{c}\text { Area } \\
\text { (square miles) }\end{array}$ \\
\hline PN & Pine Valley & 1,010 \\
CV & Crescent Valley & 750 \\
CL & Carico Lake Valley & 380 \\
UR & Upper Reese River Valley & 1,140 \\
AV & Antelope Valley & 450 \\
MR & Middle Reese River Valley & 320 \\
LR & Lower Reese River Valley & 600 \\
WV & Whirlwind Valley & 100 \\
BF & Boulder Flat & 540 \\
RL & Rock Creek Valley & 450 \\
WL & Willow Creek Valley & 410 \\
CA & Clovers Area & 720 \\
PV & Pumpernickel Valley & 310 \\
KC & Kelly Creek Area & 300 \\
\cline { 3 - 3 } & & Total............ \\
\hline
\end{tabular}

within the Humboldt River Basin. Research results were published in a wide variety of reports; one of the resulting publications was a reconnaissance-level evaluation of the Humboldt River Basin by Eakin and Lamke (1966).

Additionally, in 1960, the USGS began a cooperative study with the Nevada Department of Conservation and Natural Resources to provide preliminary appraisals of Nevada's water resources. These appraisals were published as a series of reconnaissance reports authorized by the Nevada State Legislature (Statutes, Chapter 181, 1960). Published within that series were brief water-resources appraisals for Pine Valley (Eakin, 1961), Antelope and Middle Reese River Valleys (Crosthwaite, 1963), Upper Reese River Valley (Eakin and others, 1965), and Grass and Carico Lake Valleys (Everett and Rush, 1966).

Water budgets for other hydrographic areas were appraised for Crescent Valley (Zones, 1961); for parts of Whirlwind Valley and Crescent Valley (Olmsted and Rush, 1987); and for Willow Creek Valley, Rock Creek Valley, and Boulder Flat (Maurer and others, 1996). Estimates of annual surface- and ground-water flows between hydrographic areas of Nevada and, where data were available, estimates of annual runoff, perennial yield, and water storage were summarized by Rush and others (1971).

As a result of activities from phase 1 of the Humboldt River Basin Assessment, Plume and Ponce (1999) described the hydrogeologic framework, ground-water levels, and water-level changes in the middle Humboldt River Basin. Also as a result of phase 1, Berger (2000) described methods for developing annual water budgets and presented the results of applying those methods to three hydrographic areas in the middle Humboldt River Basin.

\section{Development of Annual Water Budgets}

The approach taken for the development of water budgets for the 14 hydrographic areas in the middle Humboldt River Basin was described in detail by Berger (2000). Each hydrographic area was subdivided on the basis of three general landforms and associated patterns of ground-water flow. A water budget for each landform was estimated and then combined to develop a water budget for the entire hydrographic area. 
Data management and processing procedures used to regionalize point measurements were facilitated by using geographic information systems (GIS). The spatial-data sets developed and used in this investigation include land-surface altitude, determined from 1-degree digital elevation models (U.S. Geological Survey, 1987); land-use and land-cover digital data, derived from high-altitude photography collected in 1980 and 1983, at a scale of 1:250,000 (U.S. Geological Survey, 1986); Landsat Thematic Mapper (TM) satellite data, collected in June 1989 and June 1995; hydrographic areas and watershed boundaries digitized from 1:24,000-scale topographic maps; and distribution of geologic units, modified from Plume and Carlton (1988) and Hess and Johnson (1997).

\section{Conceptualization of a Hydrologic System}

Mountain blocks, piedmont slopes, and valley lowlands are three easily identifiable landforms in the hydrographic areas (Peterson, 1981, p. 4). The landforms are interconnected in terms of water movement but differ in their relative positions in an area and in the characteristics of ground-water flow. Schematic diagrams and general patterns of ground-water flow for a typical hydrographic area underlain by permeable and poorly permeable bedrock are shown in figure 2 . The diagrams depict ground-water movement perpendicular to the long axis of a hydrographic area. In the study area, ground water also moves parallel to the long axis and commonly supports subsurface outflow.

Mountain-block areas represent the zone of recharge and were delineated by the topographic divide along the mountain crest and by the contact between bedrock of the mountain block and the alluvial sediments of the upper piedmont slopes. Patterns and characteristics of ground-water flow are controlled by the permeability of the hydrogeologic units and the aridity of the area. Poorly permeable bedrock enhances runoff to adjacent piedmont slopes. In the Humboldt River Basin, mountain blocks receive a large part of the annual precipitation and are the principal source areas of inflow.
Piedmont slopes represent the zone of lateral flow and commonly form the largest part of a hydrographic area. Piedmont slopes typically make up the transition between the mountain block and the nearly level land of the valley lowlands (fig. 2). For most hydrographic areas, the zone of recharge extends to the upper parts of the piedmont slope, where runoff is concentrated and sediment permeability tends to be more favorable for infiltration. Textures of sediments that are on piedmont-slope surfaces typically grade from coarser grained near the mountain front to finer grained downslope toward the valley lowlands. Because of the coarse grain size of the upslope sediments, runoff that issues from the mountain block commonly infiltrates before reaching the valley lowlands. Consequently, piedmont slopes are favorable areas for ground-water recharge. Basin-fill aquifers, which make up part of the principal hydrogeologic unit beneath piedmont slopes, consist of unconsolidated to semiconsolidated deposits of poorly sorted gravel, sand, and silt.

In most hydrographic areas, the valley lowland is in the axial part and typically contains the principal tributary of the drainage basin. These tributaries are mostly ephemeral in the middle Humboldt River Basin. For this study, valley lowlands include the zone of discharge. However, in hydrographic areas where groundwater flow is part of a regional flow system and where depth to ground water is too great to sustain phreatophyte vegetation or large amounts of ground-water discharge by direct evaporation, valley lowlands may not correspond to the zone of ground-water discharge. In general, population and agricultural development are concentrated in the valley lowlands, where depth to ground water commonly is shallow. Because of the shallow water table in these generally undeveloped areas, ground-water discharge by bare-soil evaporation and phreatophytic transpiration are the dominant hydrologic processes. Unconsolidated deposits, which typically are several thousand feet thick, form the principal hydrogeologic unit beneath the valley lowlands. The basin-fill aquifers beneath piedmont-slope and valley-lowland areas are the primary aquifers developed in most hydrographic areas of the middle Humboldt River Basin. 


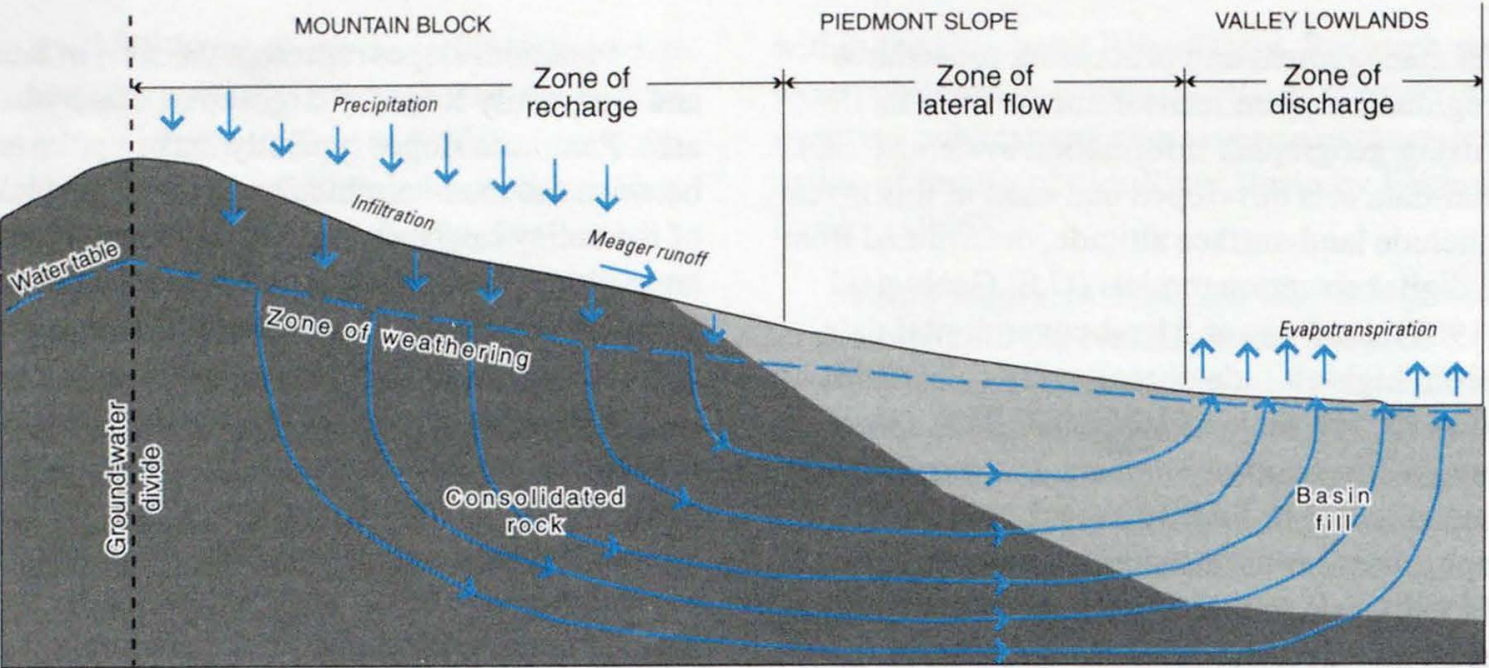

$B$

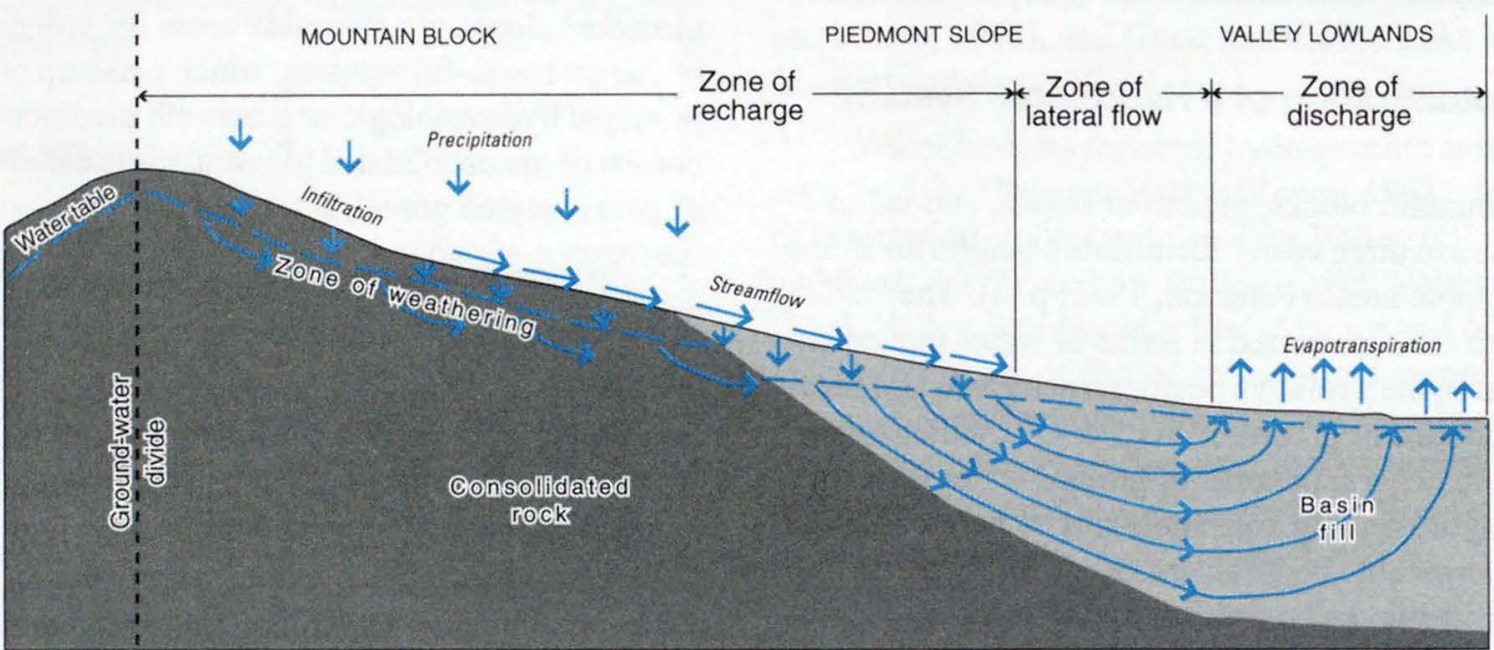

C

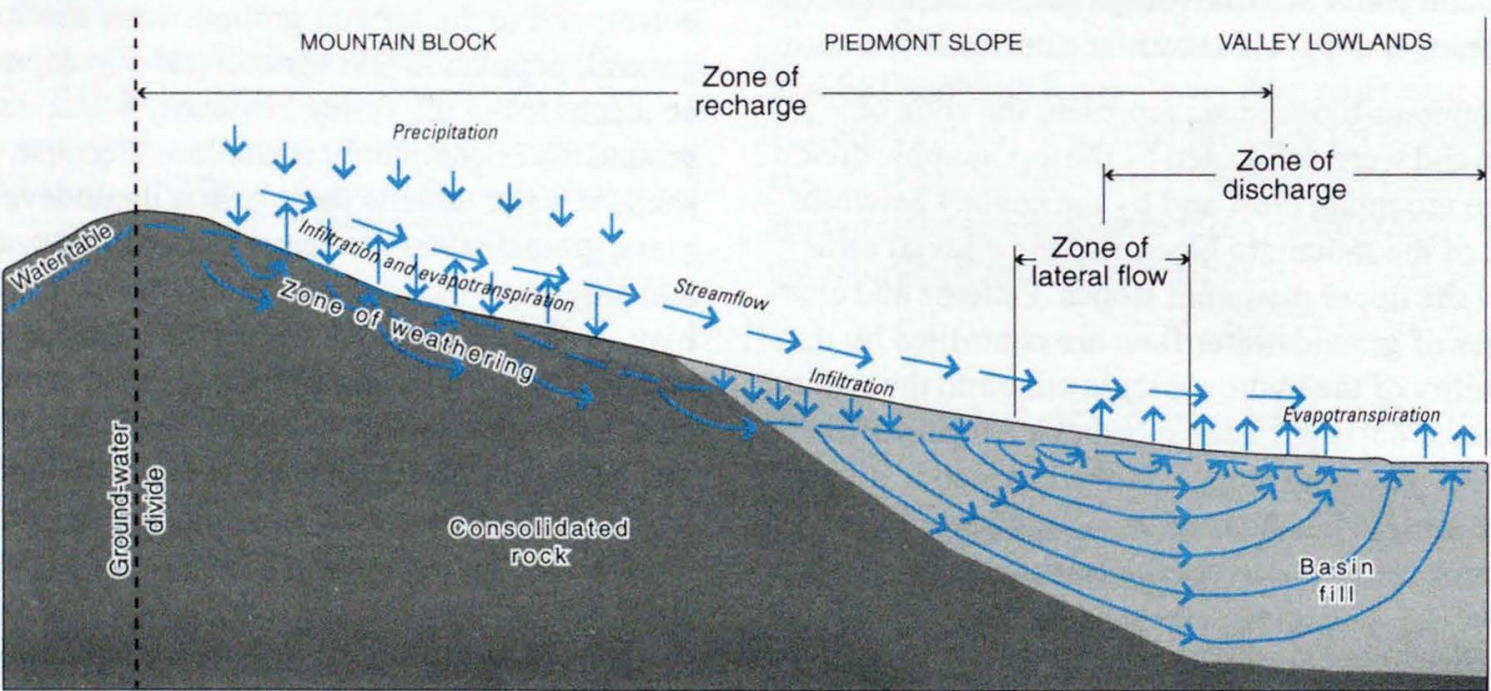

Figure 2. Typical basins, showing landforms and general patterns of ground-water movement, middle Humboldt River Basin, north-central Nevada. A, Arid basin having permeable bedrock. $B$, Arid basin having poorly permeable bedrock. $C$, Semiarid basin having poorly permeable bedrock. 


\section{Summary of Methods for Estimating Water- Budget Components}

The water budgets were developed assuming approximate equilibrium and no long-term average annual change in ground-water storage (steady-state conditions). However, stresses that include changing patterns of inflow and outflow would disrupt this hydrologic equilibrium and cause ground-water levels to fluctuate. In turn, such fluctuations would cause changes in ground-water storage.

The general relation for a steady-state water budget equates inflow to outflow. This general assumption of equilibrium was used to develop relations between inflow and outflow for each landform. The equations used to estimate average annual water budgets for a typical hydrographic area in the middle Humboldt River Basin are presented in table 2. The equations for each landform are described in terms of inflows balanced by outflows, where an outflow from one landform commonly represents an inflow to another landform. Relations among the budget components are illustrated schematically in figure 3 .

By definition, a method is a regular and systematic way of accomplishing a given task, and the assumption is that the set of procedures can be applied elsewhere and produce similar results. Thus, the methods applied to one hydrographic area should be applicable to other areas in the middle Humboldt River Basin without significant modification. Nonetheless, the procedures discussed herein are subject to refinement as more information about the identified waterbudget components becomes available. In addition, the use of these methods is limited by uncertainties inherent in measured or estimated values of the budget components and in the techniques used to areally distribute those values. Although the water budgets derived by these methods are subject to uncertainty, the overall estimates are believed to represent the proportional distribution of those components within each landform averaged over a selected reference period.

For this investigation, the water budgets were considered on an average annual basis. Therefore, estimates of precipitation, runoff, water yield, groundwater recharge, and ET represent average quantities for a 12-month period. The water year, which begins on October 1 and ends on September 30 of the following calendar year, is used to represent an average year. The 30-year period 1961-90 is used as the reference period for analyses in this investigation.

Table 2. Equations of hydrologic equilibrium for average annual water budgets for landforms and typical basin in middle Humboldt River Basin, north-central Nevada

\begin{abstract}
[Water-budget components (inflow equals outflow; see fig. 3 for hydrologic relations): Esw, evaporation from open-water bodies; ETgw, evapotranspiration of ground water by phreatophyte vegetation and through areas of bare soil in valley lowland; ETmb, evapotranspiration and sublimation of precipitation and soil moisture and from riparian areas in mountain block; ETps, evapotranspiration and sublimation of precipitation and soil moisture from piedmont slope; ETrps, evapotranspiration from vegetated flood plains of piedmont slope; ETVl, evapotranspiration of precipitation and soil moisture from valley lowland; Pmb, precipitation on mountain block; Pps, precipitation on piedmont slope; PVl, precipitation on valley lowland; ROmb, runoff from mountain block; ROps, runoff from piedmont slope; ROV, runoff from valley lowland; SFin, subsurface flow from adjacent hydrographic areas; SFmb, subsurface flow from bedrock aquifer in mountain block; SFout, subsurface flow to adjacent hydrographic areas; SFps, subsurface flow from basin-fill aquifer beneath piedmont slope; SFtot, total outflow as subsurface flow at hydrographic-area boundary; SFvl, subsurface flow from basin-fill aquifer beneath valley lowland; SWin, surface-water flow from adjacent hydrographic areas; SWtot, total outflow as surface water at hydrographic-area boundary (may include ground-water discharge as baseflow)]
\end{abstract}

\begin{tabular}{|c|c|c|c|}
\hline & \multicolumn{3}{|c|}{ Average annual water-budget components } \\
\hline & Inflow & $=$ & Outflow \\
\hline \multicolumn{4}{|l|}{ Landforms: } \\
\hline Mountain block & Pmb + SFin & $=$ & $R O m b+S F m b+S F o u t+E T m b$ \\
\hline Piedmont slope & $\mathrm{Pps}+\mathrm{ROmb}+\mathrm{SWin}+\mathrm{SFmb}+\mathrm{SFin}$ & $=$ & ROps + SFps + SFout + ETps + ETrps \\
\hline Valley lowland & $\mathrm{PVI}+\mathrm{ROps}+\mathrm{SWin}+\mathrm{SFps}+\mathrm{SFin}$ & $=$ & $\mathbf{R O V I}+\mathbf{S F v l}+\mathbf{E T V l}+\mathbf{E T g w}+\mathbf{E S w}$ \\
\hline Hydrographic area........ & $\mathrm{Pmb}+\mathrm{Pps}+\mathrm{Pvl}+\mathrm{SWIn}+\mathrm{SFIn}$ & $=$ & SWtot + SFtot + ETmb + ETpS + ETrps + ETVI + ETgW + EsW \\
\hline
\end{tabular}




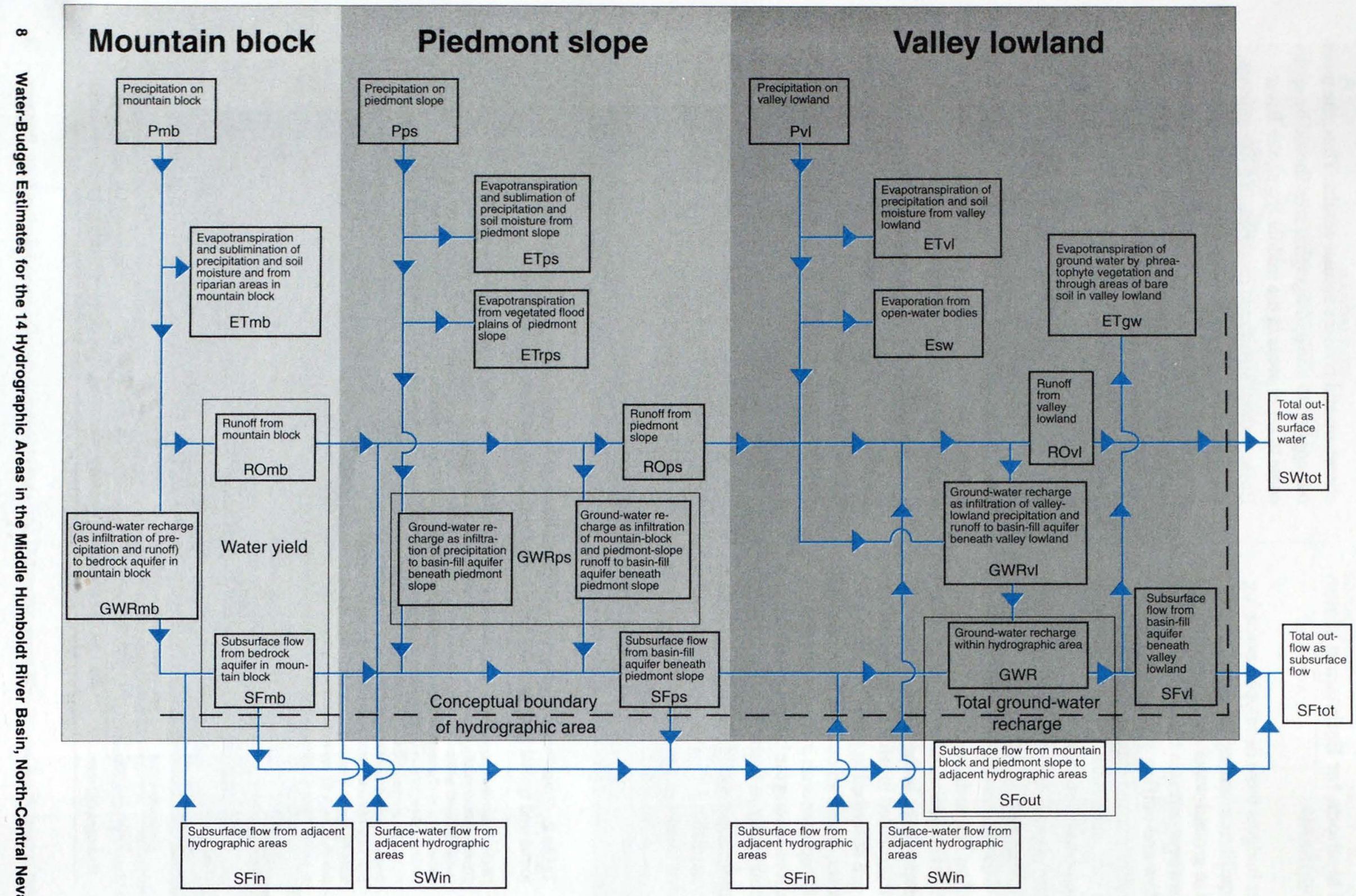

Figure 3. Interrelations among water-budget components and landforms for simplified hydrologic-flow system, middle Humboldt River Basin, north-central Nevada. Modified from Eakin and Lamke (1966, p. 14). 
Precipitation, in the form of either rain or snow, is the principal source of inflow to the Humboldt River Basin. A precipitation map derived from a statisticaltopographic model (Daly and others, 1994) was used to estimate average annual precipitation in the 14 hydrographic areas. The model, called a precipitation-elevation regressions on independent slopes model (PRISM), uses average annual precipitation over the 30-year reference period 1961-90. Methods for estimating average annual runoff, water yield, and groundwater recharge were developed, in part, as functions of the distribution and quantity of annual precipitation simulated by PRISM. The methods were regionalized by using GIS techniques (Berger, 2000). A summary of the area and distribution of average annual precipitation simulated by PRISM for each landform in the 14 hydrographic areas is presented in table 3.

Runoff is defined as that part of the precipitation that eventually appears in streams (Langbein and Iseri, 1960 , p. 17) and that can be divided, with respect to the water source, into direct runoff or baseflow runoff (Wilson and Moore, 1998, p. 172). The water yield from mountain-block areas consists of runoff generated in the watershed and of ground water that flows from the bedrock aquifer along the mountain front. The relation between runoff and water yield was used to develop estimates of subsurface flow from mountainblock areas (Berger, 2000). The difference between runoff and water yield was assumed equal to the subsurface-flow component from the mountain block.

For selected watersheds in western Nevada, a regression analysis was developed for estimating annual runoff and water yield as a function of average annual precipitation (Maurer and Berger, 1997, p. 30). This analysis was modified by Berger (2000) to include six watersheds in north-central Nevada for application in the Humboldt River Basin Assessment. Average annual-runoff values for the six watersheds in northcentral Nevada were adjusted to represent a common 31-year time period (1966-96) on the basis of available records from the South Twin River gaging station in north-central Nevada. Annual volumes of precipitation and estimates of average annual runoff and water yield were divided by the area of each watershed to account for differences in area. Simple least-squares regression analyses of average annual runoff and water yield (dependent variables) and average annual precipitation (independent variable) was done. The regression equation used to describe the relation between average annual runoff and average annual precipitation in the 14 hydrographic areas of the middle Humboldt River Basin (Berger, 2000) can be written as

$$
\mathrm{ROmb}=0.0000228\left(P_{\mathrm{m}}\right)^{3.96}
$$

where $\mathrm{ROmb}$ is estimated average annual runoff in mountain block, in inches per year; and

$P_{\mathrm{m}}$ is average annual precipitation in mountain block, in inches per year.

On the basis of the coefficient of determination for equation $1\left(r^{2}=0.887\right)$, about 89 percent of the variance in annual runoff from the selected watersheds can be explained by the regression relation. In addition, the significance of probability $(p=0.0001)$ indicates a statistically significant relation between average annual precipitation simulated by PRISM and adjusted average annual runoff.

The equation that best approximates the relation between average annual water yield and precipitation in the 14 hydrographic areas of the middle Humboldt River Basin (Berger, 2000) can be written as

$$
W=0.00273\left(P_{\mathrm{m}}\right)^{2.56}
$$

where $W$ is average annual water yield in mountain block, in inches per year; and

$P_{\mathrm{m}}$ is average annual precipitation in mountain block, in inches per year.

According to the coefficient of determination $\left(r^{2}=\right.$ 0.863 ), about 86 percent of the variance in average annual water yield can be accounted for by this regression equation. The small $\mathrm{p}$-value, 0.0008 , indicates a strong predictive relation between average annual water yield and precipitation. Estimates of average annual runoff and water yield for mountain-block areas of the 14 hydrographic areas are presented in table 4 . The coefficients derived for equations 1 and 2 are applicable only to the distribution of precipitation simulated by PRISM and acquired from G.H. Taylor (Oregon Climate Service, Oregon State University, written commun., 1997). Relations represented by equations 1 and 2 are applicable for watersheds with PRISM-simulated average annual precipitation of not more than about 30 in. 
Table 3. Area of landforms and distribution of simulated average annual precipitation on landforms in the 14 hydrographic areas of middle Humboldt River Basin, north-central Nevada

[Simulation based on 1961-90 data. Model simulated no annual precipitation of less than 8 inches or greater than 30 inches. Precipitation zones based on Nichols (2000). Data for individual landforms rounded to nearest 100 acres or acre-feet per year; totals, to nearest 1,000. PRISM, precipitation-elevation regressions on independent slopes model (Daly and others, 1994). <, less than]

\begin{tabular}{|c|c|c|c|c|c|c|}
\hline \multirow[b]{2}{*}{ Landform } & \multirow[b]{2}{*}{$\begin{array}{c}\text { Area } \\
\text { (acres) }\end{array}$} & \multicolumn{5}{|c|}{$\begin{array}{l}\text { PRISM-simulated average annual precipitation by precipitation zone } \\
\qquad \text { (acre-feet per year) }\end{array}$} \\
\hline & & $\begin{array}{l}\text { Zone of } \\
\text { at least } 8 \\
\text { but }<12 \\
\text { inches }\end{array}$ & $\begin{array}{c}\text { Zone of } \\
\text { at least } 12 \\
\text { but }<16 \\
\text { inches }\end{array}$ & $\begin{array}{l}\text { Zone of } \\
\text { at least } 16 \\
\text { but }<20 \\
\text { inches }\end{array}$ & $\begin{array}{l}\text { Zone of } \\
\text { at least } 20 \\
\text { but }<34 \\
\text { inches }\end{array}$ & Total \\
\hline \multicolumn{7}{|c|}{ Pine Valley Hydrographic Area } \\
\hline Mountain block & 261,800 & 10,600 & 177,600 & 117,200 & 21,000 & 326,000 \\
\hline Piedmont slope & 350,100 & 174,700 & 151,400 & 7,700 & 0 & 334,000 \\
\hline Valley lowland & 32,800 & 26,300 & 1,500 & 0 & 0 & 28,000 \\
\hline Total...... & 645,000 & 212,000 & 330,000 & 125,000 & 21,000 & 688,000 \\
\hline \multicolumn{7}{|c|}{ Crescent Valley Hydrographic Area } \\
\hline Mountain block & 179,800 & 65,200 & 95,200 & 22,200 & 1,500 & 184,000 \\
\hline Piedmont slope & 224,000 & 161,000 & 31,400 & 4,300 & 0 & 197,000 \\
\hline Valley lowland & 78,100 & 65,100 & 0 & 0 & 0 & 65,000 \\
\hline Total...... & 482,000 & 291,000 & 127,000 & 26,000 & 2,000 & 446,000 \\
\hline \multicolumn{7}{|c|}{ Carico Lake Valley Hydrographic Area } \\
\hline Mountain block & 111,400 & 20,200 & 77,300 & 22,100 & 3,400 & 123,000 \\
\hline Piedmont slope & 120,400 & 82,300 & 25,300 & 0 & 0 & 108,000 \\
\hline Valley lowland & 9,700 & 8,100 & 0 & 0 & 0 & 8,000 \\
\hline Total....... & 242,000 & 111,000 & 103,000 & 22,000 & 3,000 & 239,000 \\
\hline \multicolumn{7}{|c|}{ Upper Reese River Valley Hydrographic Area } \\
\hline Mountain block & 339,200 & 32,600 & 200,600 & 135,400 & 45,300 & 414,000 \\
\hline Piedmont slope & 352,100 & 78,800 & 269,600 & 6,100 & 0 & 354,000 \\
\hline Valley lowland & 36,000 & 5,500 & 29,500 & 0 & 0 & 35,000 \\
\hline Total....... & 727,000 & 117,000 & 500,000 & 142,000 & 45,000 & 803,000 \\
\hline \multicolumn{7}{|c|}{ Antelope Valley Hydrographic Area } \\
\hline Mountain block & 114,000 & 26,700 & 86,500 & 7,000 & 0 & 120,000 \\
\hline Piedmont slope & 145,300 & 88,200 & 45,800 & 100 & 0 & 134,000 \\
\hline Valley lowland & 30,300 & 25,300 & 0 & 0 & 0 & 25,000 \\
\hline Total....... & 290,000 & 140,000 & 132,000 & 7,000 & 0 & 279,000 \\
\hline \multicolumn{7}{|c|}{ Middle Reese River Valley Hydrographic Area } \\
\hline Mountain block & 113,500 & 44,800 & 65,200 & 0 & 0 & 110,000 \\
\hline Piedmont slope & 54,200 & 42,100 & 4,300 & 0 & 0 & 46,000 \\
\hline Valley lowland & 36,200 & 30,100 & 0 & 0 & 0 & 30,000 \\
\hline Total....... & 204,000 & 117,000 & 70,000 & 0 & 0 & 186,000 \\
\hline \multicolumn{7}{|c|}{ Lower Reese River Valley Hydrographic Area } \\
\hline Mountain block & 151,200 & 66,000 & 80,900 & 0 & 0 & 147,000 \\
\hline Piedmont slope & 123,700 & 101,000 & 3,100 & 0 & 0 & 104,000 \\
\hline Valley lowland & 107,600 & 89,700 & 0 & 0 & 0 & 90,000 \\
\hline Total...... & 382,000 & 257,000 & 84,000 & 0 & 0 & 341,000 \\
\hline
\end{tabular}


Table 3. Area of landforms and distribution of simulated average annual precipitation on landforms in the 14 hydrographic areas of middle Humboldt River Basin, north-central Nevada-Continued

\begin{tabular}{|c|c|c|c|c|c|c|}
\hline \multirow[b]{2}{*}{ Landform } & \multirow[b]{2}{*}{$\begin{array}{c}\text { Area } \\
\text { (acres) }\end{array}$} & \multicolumn{5}{|c|}{$\begin{array}{l}\text { PRISM-simulated average annual precipitation by precipitation zone } \\
\qquad \text { (acre-feet per year) }\end{array}$} \\
\hline & & $\begin{array}{c}\text { Zone of } \\
\text { at least } 8 \\
\text { but }<12 \\
\text { inches }\end{array}$ & $\begin{array}{l}\text { Zone of } \\
\text { at least } 12 \\
\text { but }<16 \\
\text { inches }\end{array}$ & $\begin{array}{l}\text { Zone of } \\
\text { at least } 16 \\
\text { but }<20 \\
\text { inches }\end{array}$ & $\begin{array}{l}\text { Zone of } \\
\text { at least } 20 \\
\text { but }<34 \\
\text { inches }\end{array}$ & Total \\
\hline \multicolumn{7}{|c|}{ Whirlwind Valley Hydrographic Area } \\
\hline Mountain block & 38,300 & 25,400 & 8,700 & 0 & 0 & 34,000 \\
\hline Piedmont slope & 12,800 & 10,000 & 900 & 0 & 0 & 11,000 \\
\hline Valley lowland & 11,500 & 9,600 & 0 & 0 & 0 & 10,000 \\
\hline Total...... & 63,000 & 45,000 & 10,000 & 0 & 0 & 55,000 \\
\hline \multicolumn{7}{|c|}{ Boulder Flat Hydrographic Area } \\
\hline Mountain block & 150,400 & 80,000 & 54,700 & 7,200 & 0 & 142,000 \\
\hline Piedmont slope & 77,000 & 59,200 & 6,800 & 0 & 0 & 66,000 \\
\hline Valley lowland & 119,700 & 99,700 & 0 & 0 & 0 & 100,000 \\
\hline Total...... & 347,000 & 239,000 & 62,000 & 7,000 & 0 & 308,000 \\
\hline \multicolumn{7}{|c|}{ Rock Creek Valley Hydrographic Area } \\
\hline Mountain block & 221,500 & 141,300 & 53,800 & 4,200 & 0 & 199,000 \\
\hline Piedmont slope & 56,300 & 45,600 & 2,200 & 0 & 0 & 48,000 \\
\hline Valley lowland & 10,300 & 8,300 & 400 & 0 & 0 & 9,000 \\
\hline Total...... & 288,000 & 195,000 & 56,000 & 4,000 & 0 & 256,000 \\
\hline \multicolumn{7}{|c|}{ Willow Creek Valley Hydrographic Area } \\
\hline Mountain block & 196,200 & 37,300 & 137,600 & 33,800 & 7,800 & 216,000 \\
\hline Piedmont slope & 57,300 & 26,600 & 22,500 & 4,900 & 1,400 & 55,000 \\
\hline Valley lowland & 10,700 & 8,900 & 200 & 0 & 0 & 9,000 \\
\hline Total....... & 264,000 & 73,000 & 160,000 & 39,000 & 9,000 & 280,000 \\
\hline \multicolumn{7}{|c|}{ Clovers Area } \\
\hline Mountain block & 138,300 & 65,400 & 49,800 & 22,100 & 0 & 137,000 \\
\hline Piedmont slope & 193,400 & 151,600 & 7,900 & 400 & 0 & 160,000 \\
\hline Valley lowland & 130,300 & 103,600 & 0 & 0 & 0 & 104,000 \\
\hline Total...... & 462,000 & 321,000 & 58,000 & 22,000 & 0 & 401,000 \\
\hline \multicolumn{7}{|c|}{ Pumpernickel Valley Hydrographic Area } \\
\hline Mountain block & 78,900 & 35,300 & 37,600 & 1,200 & 0 & 74,000 \\
\hline Piedmont slope & 67,700 & 46,700 & 11,600 & 0 & 0 & 58,000 \\
\hline Valley lowland & 49,100 & 36,600 & 0 & 0 & 0 & 37,000 \\
\hline Total...... & 196,000 & 119,000 & 49,000 & 1,000 & 0 & 169,000 \\
\hline \multicolumn{7}{|c|}{ Kelly Creek Area } \\
\hline Mountain block & 60,800 & 7,600 & 35,700 & 16,800 & 12,700 & 73,000 \\
\hline Piedmont slope & 81,000 & 59,700 & 9,800 & 200 & 0 & 70,000 \\
\hline Valley lowland & 51,000 & 37,600 & 0 & 0 & 0 & 38,000 \\
\hline Total....... & 193,000 & 105,000 & 46,000 & 17,000 & 13,000 & 181,000 \\
\hline
\end{tabular}


Table 4. Simulated average annual precipitation and estimated average annual runoff, water yield, subsurface flow, and evapotranspiration in mountain-block areas in the 14 hydrographic areas of middle Humboldt River Basin, north-central Nevada

[PRISM, precipitation-elevation regressions on independent slopes model (Daly and others, 1994)]

\begin{tabular}{|c|c|c|c|c|c|c|}
\hline \multirow[b]{2}{*}{ Hydrographic area } & \multicolumn{2}{|c|}{$\begin{array}{l}\text { Average annual } \\
\text { precipitation }^{1}\end{array}$} & \multirow{2}{*}{$\begin{array}{c}\text { Average annual } \\
\text { runoff } \\
\text { (acre-feet }^{2} \\
\text { per year) }\end{array}$} & \multirow{2}{*}{$\begin{array}{c}\text { Average annual } \\
\text { water yield } \\
\text { (acre-feet }^{3} \\
\text { per year) }\end{array}$} & \multirow{2}{*}{$\begin{array}{c}\text { Average annual } \\
\text { subsurface flow } \\
\text { (acre-feet } \\
\text { per year) }\end{array}$} & \multirow{2}{*}{$\begin{array}{c}\text { Average annual } \\
\text { evapotranspiration } \\
\text { (acre-feet } \\
\text { per year) }\end{array}$} \\
\hline & $\begin{array}{c}\text { Rate } \\
\text { (inches } \\
\text { per year) }\end{array}$ & $\begin{array}{l}\text { Volume } \\
\text { (acre-feet } \\
\text { per year) }\end{array}$ & & & & \\
\hline Pine Valley & 14.96 & 326,400 & 22,400 & 60,600 & 38,200 & 265,800 \\
\hline Crescent Valley & 12.29 & 184,100 & 7,000 & 25,200 & 18,200 & 158,900 \\
\hline Carico Lake Valley & 13.25 & 123,000 & 5,900 & 18,900 & 13,000 & 104,100 \\
\hline Upper Reese River Valley & 14.64 & 413,900 & 26,600 & 74,300 & 47,700 & 339,600 \\
\hline Antelope Valley & 12.65 & 120,200 & 5,000 & 17,200 & 12,200 & 103,000 \\
\hline Middle Reese River Valley & 11.63 & 110,000 & 3,600 & 13,800 & 10,200 & 96,200 \\
\hline Lower Reese River Valley & 11.66 & 146,900 & 4,800 & 18,500 & 13,700 & 128,400 \\
\hline Whirlwind Valley & 10.68 & 34,100 & 900 & 3,700 & 2,800 & 30,400 \\
\hline Boulder Flat & 11.32 & 141,900 & 4,300 & 17,100 & 12,800 & 124,800 \\
\hline Rock Creek Valley & 10.80 & 199,300 & 5,200 & 22,300 & 17,100 & 177,000 \\
\hline Willow Creek Valley & 13.24 & 216,500 & 10,300 & 33,200 & 22,900 & 183,300 \\
\hline Clovers Area & 11.91 & 137,300 & 4,800 & 17,900 & 13,100 & 119,400 \\
\hline Pumpernickel Valley & 11.27 & 74,100 & 2,200 & 8,800 & 6,600 & 65,300 \\
\hline Kelly Creek Area & 14.37 & 72,800 & 4,400 & 12,700 & 8,300 & 60,100 \\
\hline
\end{tabular}

\footnotetext{
${ }^{1}$ PRISM simulation based on 1961-90 data; rate rounded to nearest 0.01 inch per year, and volume, to nearest 100 acre-feet per year.

${ }^{2}$ ROmb, estimated from equation 1 (see text); rounded to nearest 100 acre-feet per year.

${ }^{3}$ Estimated from equation 2 (see text); rounded to nearest 100 acre-feet per year.

${ }^{4}$ From bedrock aquifers in mountain-block areas to basin fill underlying piedmont-slope areas and to adjacent hydrographic areas. SFmb, estimated as difference between average annual water yield and average annual runoff; rounded to nearest 100 acre-feet per year.

${ }^{5}$ ETmb, estimated as difference between average annual precipitation in mountain-block areas and average annual water yield; includes sublimated precipitation and soil moisture; rounded to nearest 100 acre-feet per year.
}

The portion of precipitation that falls on piedmont slopes and becomes runoff is largely unknown. Runoff generated in piedmont-slope areas from short periods of high-intensity storms or low-altitude snowmelts is erratic in occurrence and probably accounts for less than 10 percent of the total runoff but could be greater. Eakin and Lamke (1961, p. 32) estimated that about 7 percent of the total runoff occurs in valley-upland areas. To develop a generalized water budget, average annual runoff originating from precipitation on piedmont-slope areas was estimated to range from 0 to 10 percent of the total runoff generated in the hydrographic area (table 5). The low end of this range reflects the possibility that all the annual precipitation on piedmont-slope areas is lost to either ET or ground-water recharge. Runoff generated in valley-lowland areas was assumed to be negligible; consequently, total surface-water outflow at the hydrographic-area boundary equaled the net sum of runoff generated in the mountain block and on the piedmont slope and the volume contributed by ground-water discharge.
Ground-water recharge takes place by direct infiltration of precipitation in excess of ET and soil-moisture requirements and by indirect infiltration from channelized or nonchannelized runoff or ponded water. Although, in terms of total ground-water recharge, indirect processes of recharge tend to be seasonal, they are significant to the overall water budget of a basin.

Two approaches were taken to estimate groundwater recharge. The first approach is based on an empirical relation between precipitation and groundwater recharge similar to that developed by Maxey and Eakin (1949) and Eakin and others (1951). For each basin, average annual precipitation was distributed into four zones. Multiple-regression analysis then was used to develop recharge coefficients to describe the relation between precipitation and ground-water recharge in each zone. The regression equation that best approximates this relation was derived by Nichols (2000) from 16 basins in eastern Nevada where ground-water outflow by ET and interbasin flow had been estimated previously. The regression equation can be written as 
Table 5. Estimated average annual runoff, evapotranspiration, and subsurface flow from piedmont-slope areas in the 14 hydrographic areas of middle Humboldt River Basin, north-central Nevada

[All values rounded to nearest 100 acre-feet per year. Bold symbols (in footnotes) correspond to those used in table 2 and fig. 3. PRISM, precipitationelevation regressions on independent slopes model (Daly and others, 1994); RAWS, remote automatic weather station; TM, Thematic Mapper]

\begin{tabular}{|c|c|c|c|c|}
\hline Hydrographic area & $\begin{array}{c}\text { Average annual } \\
\text { runoff }^{1} \\
\text { (acre-feet } \\
\text { per year) }\end{array}$ & $\begin{array}{l}\text { Average annual } \\
\text { evapotranspiration } \\
\text { (acre-feet } \\
\text { per year) }\end{array}$ & $\begin{array}{l}\text { Average annual } \\
\text { evapotranspiration } \\
\text { from vegetated } \\
\text { floodplains } \\
\text { (acre-feet } \\
\text { per year) }\end{array}$ & $\begin{array}{l}\text { Average annual } \\
\text { subsurface flow } \\
\text { (acre-feet } \\
\text { per year) }\end{array}$ \\
\hline Pine Valley & $0-2,500$ & $306,300-333,800$ & $3,200-4,100$ & $52,500-79,300$ \\
\hline Crescent Valley & $0-800$ & $196,000-196,700$ & $500-1,900$ & $25,500-26,500$ \\
\hline Carico Lake Valley & $0-700$ & $105,400-107,600$ & $1,100-1,200$ & $21,700-23,400$ \\
\hline Upper Reese River Valley & $0-3,000$ & $308,100-354,500$ & $10,900-11,700$ & $71,400-110,000$ \\
\hline Antelope Valley & $0-600$ & $127,100-134,100$ & $200-600$ & $17,200-25,200$ \\
\hline Middle Reese River Valley & $0-400$ & 46,400 & $300-800$ & $13,300-13700$ \\
\hline Lower Reese River Valley & $0-500$ & 104,100 & 100 & $18,500-19,000$ \\
\hline Whirlwind Valley & $0-100$ & 10,900 & 0 & $3,700-3,800$ \\
\hline Boulder Flat & $0-500$ & 66,000 & $300-700$ & $19,100-19,300$ \\
\hline Rock Creek Valley & $0-600$ & 47,800 & $600-800$ & 17,100 \\
\hline Willow Creek Valley & $0-1,100$ & $50,100-55,400$ & $3,300-4,200$ & 27,500 \\
\hline Clovers Area & $0-500$ & 159,900 & $4,400-7,600$ & $17,900-18,400$ \\
\hline Pumpernickel Valley & $0-200$ & 58,300 & $500-700$ & $8,800-9,000$ \\
\hline Kelly Creek Area & $0-500$ & 69,700 & $1,600-2,300$ & $12,700-13,200$ \\
\hline
\end{tabular}

$$
R_{\mathrm{gw}}=0.008\left(P_{\mathrm{a}}\right)+0.130\left(P_{\mathrm{b}}\right)+0.144\left(P_{\mathrm{c}}\right)+0.158\left(P_{\mathrm{d}}\right)
$$

where $R_{\mathrm{gw}}$ is average annual ground-water recharge, in acre-feet per year;

$P_{\mathrm{a}}$ is average annual volume of precipitation in hydrographic area in zone of at least 8 but less than 12 in., in acre-feet per year;

$P_{\mathrm{b}}$ is average annual volume of precipitation in hydrographic area in zone of at least 12 but less than 16 in., in acre-feet per year;

$P_{\mathrm{c}}$ is average annual volume of precipitation in hydrographic area in zone of at least 16 but less than 20 in., in acre-feet per year;

$P_{\mathrm{d}}$ is average annual volume of precipitation in hydrographic area in zone of at least 20 but less than 34 in., in acre-feet per year.
Similar to the original method developed by Maxey-Eakin (1949), this revised relation (eq. 3) provides a bulk estimate of recharge and assumes that ground-water recharge is negligible if annual precipitation is less than 8 in. The recharge coefficients derived by Nichols (2000) for estimating average annual ground-water recharge are applicable only to the distribution of precipitation simulated by PRISM and acquired from G.H. Taylor (Oregon Climate Service, Oregon State University, written commun., 1997).

The second approach, based on mass-balance calculations among several budget components, provides an indication of the quantity of ground-water recharge contributed by individual processes (Berger, 2000). This approach was used to evaluate the ground-water budget for each hydrographic area and individual budget components, particularly subsurface flow between aquifers underlying adjacent landforms. 
Although the quantity of subsurface flow that moves across hydrographic-area boundaries is generally unknown, it could represent a significant component of the water budget. Results from a study by Plume and Ponce (1999) provided most of the information needed for estimating subsurface flow by using Darcy's law. As modified from Heath (1989, p. 12), Darcy's law can be expressed as

$$
Q=0.0084 K A(\mathrm{~d} h / \mathrm{d} l),
$$

where $Q$ is quantity of subsurface flow, in acre-feet per year;

$K$ is average hydraulic conductivity for cross section, in feet per day;

$A$ is saturated cross-sectional area through which flow occurs, perpendicular to the direction of flow, in square feet;

$(\mathrm{d} h / \mathrm{d} l)$ is hydraulic gradient, in feet per feet; and

0.0084 is factor to convert cubic feet per day into acre-feet per year.

Derived from Plume and Ponce (1999), a value of $10 \mathrm{ft} / \mathrm{d}$ was used to represent an average hydraulic-conductivity value for basin-fill sediments. Cross-sectional areas of basin fill beneath hydrographic-area boundaries were estimated on the basis of interpretation of gravity data (D.A. Ponce, U.S. Geological Survey, written commun., 1997, 1999). Water-level data collected in the spring of 1996 (Plume and Ponce, 1999) were used to estimate hydraulic gradients.

Currently, no data to determine directly the loss of water by ET and sublimation are available for mountain-block areas of the Humboldt River Basin. For this investigation, ET was estimated as the difference between average annual precipitation that falls in mountain-block areas and the estimated average annual water yield (eq. 2). Average annual ET in piedmontslope areas was derived, in part, by applying the Penman-Monteith equation (Monteith, 1965) to available climatic data collected at remote automatic weather stations (Berger, 2000). An average value of $10.5 \mathrm{in} / \mathrm{yr}$, derived from the Penman-Monteith equation, was used as a minimum rate, and the annual quantity of precipitation that falls on piedmont-slope areas was used as a maximum rate.
In valley-lowland areas, total ET is assumed equal to the sum of average annual precipitation that falls within the area plus the consumptive use of ground water by phreatophyte vegetation. A method for estimating ground-water ET at regional scales by using Landsat TM satellite data was developed by Nichols (2000) and was applied to the valley lowlands to estimate average annual ground-water ET. The Landsat TM data were collected in June 1989 and June 1995. Estimates of ground-water discharge by phreatophyte vegetation in the 14 hydrographic areas is presented in table 6 . The average annual ET determined for the valley lowlands in each basin was less in 1989 than in 1995. Although the total area of phreatophyte vegetation in each basin was essentially the same for the two periods, the greater ET in 1995 was due to an increase in plant cover in the at-least-10-but-less-than-20-percent zone and a corresponding decrease in plant cover in the less-than-10-percent zone (table 6; Berger, 2000, p. 22).

ET from vegetated flood plains in piedmont-slope areas also was estimated from Landsat TM data. The methods using Landsat TM data may not be entirely appropriate for estimating ET in vegetated flood plains because of the smaller area covered by these areas compared to phreatophyte vegetation in the valley lowlands. However, the method does provide a lower ET limit for vegetated flood plains. The consumptive use of water in vegetated flood plains was assumed to represent ground-water discharge.

Evaporation from open-water bodies (table 6) was estimated on the basis of pan-evaporation measurements collected at Beowawe and Rye Patch Dam in the Humboldt River Basin and at Ruby Lake in northeastern Nevada (fig. 1; Shevenell, 1996, p. 5). An average of $4.2 \mathrm{ft} / \mathrm{yr}$ was used for estimating average annual evaporation from open-water bodies and included in the water budget for the valley lowlands. Areas of open-water bodies in the study area were determined from Landsat TM data collected in June 1989 and June 1995. 
Table 6. Average annual evapotranspiration rates from areas of bare soil or phreatophyte vegetation, evaporation rates from open water, and annual volume of ground-water evapotranspiration from valley lowlands, 1989 and 1995 , in the 14 hydrographic areas of middle Humboldt River Basin, north-central Nevada

[ET, evapotranspiration; MSAVI, modified soil-adjusted vegetation index; TM, Thematic Mapper]

\begin{tabular}{|c|c|c|c|c|c|c|}
\hline \multirow{3}{*}{ Zone } & \multirow{2}{*}{\multicolumn{2}{|c|}{$\begin{array}{l}\text { Area }^{1} \\
\text { (acres) }\end{array}$}} & \multicolumn{4}{|c|}{ Average evapotranspiration ${ }^{2}$} \\
\hline & & & \multicolumn{2}{|c|}{$\begin{array}{c}\text { Rate } \\
\text { (feet per year) }\end{array}$} & \multicolumn{2}{|c|}{$\begin{array}{c}\text { Volume } \\
\text { (acre-feet per year) }\end{array}$} \\
\hline & 1989 & 1995 & 1989 & 1995 & 1989 & 1995 \\
\hline \multicolumn{7}{|c|}{ Pine Valley Hydrographic Area } \\
\hline Bare soil & 170 & 70 & 0.15 & 0.15 & 30 & 10 \\
\hline \multicolumn{7}{|l|}{ Plant cover: } \\
\hline Less than 10 percent & 15,360 & 5,500 & .50 & .62 & 7,710 & 3,380 \\
\hline At least 10 but less than 20 percent & 9,450 & 17,530 & 1.35 & 1.36 & 12,720 & 23,810 \\
\hline At least 20 but less than 35 percent & 3,610 & 5,190 & 2.17 & 2.17 & 7,820 & 11,280 \\
\hline At least 35 but less than 50 percent & 1,990 & 3,130 & 2.55 & 2.55 & 5,080 & 7,980 \\
\hline At least 50 percent & 2,320 & 1,470 & 2.64 & 2.64 & 6,120 & 3,870 \\
\hline \multicolumn{3}{|l|}{ Estimated total annual ground-water $\mathrm{ET}^{3}}$. & 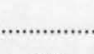 & ................. & 39,500 & 50,300 \\
\hline Open-water bodies & 16 & 15 & 4.2 & 4.2 & 70 & 60 \\
\hline \multicolumn{7}{|c|}{ Crescent Valley Hydrographic Area } \\
\hline Bare soil & 7,690 & 5,190 & 0.15 & 0.15 & 1,150 & 780 \\
\hline \multicolumn{7}{|l|}{ Plant cover: } \\
\hline Less than 10 percent & 43,740 & 33,360 & .28 & .38 & 12,120 & 12,740 \\
\hline At least 10 but less than 20 percent & 4,090 & 15,660 & 1.22 & 1.24 & 5,000 & 19,500 \\
\hline At least 20 but less than 35 percent & 550 & 1,830 & 2.10 & 2.12 & 1,150 & 3,880 \\
\hline At least 35 but less than 50 percent & 60 & 80 & 2.50 & 2.47 & 150 & 200 \\
\hline At least 50 percent & 10 & 10 & 2.58 & 2.58 & 30 & 30 \\
\hline \multicolumn{3}{|l|}{ Estimated total annual ground-water $\mathrm{ET}^{3} \ldots$} & .................. & . & 19,600 & 37,100 \\
\hline Open-water bodies & 103 & 114 & 4.2 & 4.2 & 430 & 480 \\
\hline \multicolumn{7}{|c|}{ Carico Lake Valley Hydrographic Area } \\
\hline Bare soil & 520 & 160 & 0.15 & 0.15 & 80 & 20 \\
\hline \multicolumn{7}{|l|}{ Plant cover: } \\
\hline Less than 10 percent & 7,870 & 4,680 & .31 & .57 & 2,460 & 2,660 \\
\hline At least 10 but less than 20 percent & 820 & 4,120 & 1.27 & 1.25 & 1,040 & 5,150 \\
\hline At least 20 but less than 35 percent & 260 & 430 & 2.19 & 2.14 & 570 & 920 \\
\hline At least 35 but less than 50 percent & 190 & 140 & 2.54 & 2.55 & 480 & 360 \\
\hline At least 50 percent & 80 & 190 & 2.64 & 2.64 & 210 & 500 \\
\hline Estimated total annual ground-water $\mathrm{ET}^{3}$.. & & $\ldots \ldots \ldots$ & $\ldots$ & ..................... & 4,800 & 9,600 \\
\hline Open-water bodies & 0 & 9 & 4.2 & 4.2 & 0 & 40 \\
\hline \multicolumn{7}{|c|}{ Upper Reese River Valley Hydrographic Area } \\
\hline Bare soil & 220 & 710 & 0.15 & 0.15 & 30 & 110 \\
\hline \multicolumn{7}{|l|}{ Plant cover: } \\
\hline Less than 10 percent & 14,890 & 9,900 & .44 & .47 & 6,630 & 4,670 \\
\hline At least 10 but less than 20 percent & 10,420 & 16,390 & 1.40 & 1.36 & 14,600 & 22,340 \\
\hline At least 20 but less than 35 percent & 6,420 & 5,870 & 2.18 & 2.17 & 13,980 & 12,760 \\
\hline At least 35 but less than 50 percent & 2,510 & 1,600 & 2.54 & 2.53 & 6,380 & 4,050 \\
\hline At least 50 percent & 830 & 690 & 2.64 & 2.64 & 2,190 & 1,820 \\
\hline Estimated total annual ground-water $\mathrm{ET}^{3}$. & ........ & ............ & ................... & 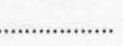 & 43,800 & 45,800 \\
\hline Open-water bodies & 4 & 150 & 4.2 & 4.2 & 20 & 630 \\
\hline
\end{tabular}


Table 6. Average annual evapotranspiration rates from areas of bare soil or phreatophyte vegetation, evaporation rates from open water, and annual volume of ground-water evapotranspiration from valley lowlands, 1989 and 1995, in the 14 hydrographic areas of middle Humboldt River Basin, north-central Nevada-Continued

\begin{tabular}{|c|c|c|c|c|c|c|}
\hline \multirow{3}{*}{ Zone } & \multirow{2}{*}{\multicolumn{2}{|c|}{$\begin{array}{l}\text { Area }^{1} \\
\text { (acres) }\end{array}$}} & \multicolumn{4}{|c|}{ Average evapotranspiration ${ }^{2}$} \\
\hline & & & \multicolumn{2}{|c|}{$\begin{array}{c}\text { Rate } \\
\text { (feet per year) }\end{array}$} & \multicolumn{2}{|c|}{$\begin{array}{c}\text { Volume } \\
\text { (acre-feet per year) }\end{array}$} \\
\hline & 1989 & 1995 & 1989 & 1995 & 1989 & 1995 \\
\hline \multicolumn{7}{|c|}{ Antelope Valley Hydrographic Area } \\
\hline Bare soil & 60 & 0 & 0.15 & 0.15 & 10 & 0 \\
\hline \multicolumn{7}{|l|}{ Plant cover: } \\
\hline Less than 10 percent & 6,970 & 1,690 & .23 & .69 & 1,620 & 1,160 \\
\hline At least 10 but less than 20 percent & 200 & 5,460 & 1.20 & 1.26 & 310 & 6,890 \\
\hline At least 20 but less than 35 percent & 10 & 140 & 2.09 & 2.08 & 20 & 290 \\
\hline At least 35 but less than 50 percent & 0 & 10 & 2.47 & 2.45 & 0 & 20 \\
\hline At least 50 percent & 0 & 0 & 0.00 & 0.00 & 0 & 0 \\
\hline Estimated total annual ground-water $\mathrm{ET}^{3} \ldots$ & & & ................... & $\ldots$ & 2,000 & 8,400 \\
\hline Open-water bodies & 0 & 0 & 4.2 & 4.2 & 0 & 0 \\
\hline \multicolumn{7}{|c|}{ Middle Reese River Valley Hydrographic Area } \\
\hline Bare soil & 230 & 30 & 0.15 & 0.15 & 30 & 0 \\
\hline \multicolumn{7}{|l|}{ Plant cover: } \\
\hline Less than 10 percent & 9,360 & 3,240 & .17 & .54 & 1,560 & 1,730 \\
\hline At least 10 but less than 20 percent & 370 & 5,530 & 1.34 & 1.39 & 500 & 7,751 \\
\hline At least 20 but less than 35 percent & 100 & 1,110 & 2.10 & 2.06 & 210 & 2,290 \\
\hline At least 35 but less than 50 percent & 20 & 110 & 2.51 & 2.51 & 50 & 280 \\
\hline At least 50 percent & 0 & 60 & 2.58 & 2.59 & 0 & 160 \\
\hline Estimated total annual ground-water $\mathrm{ET}^{3} \ldots$ & .................. & 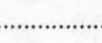 & (n)................ & (...................... & 2,400 & 12,200 \\
\hline Open-water bodies & 2 & 8 & 4.2. & 4.2 & 10 & 30 \\
\hline \multicolumn{7}{|c|}{ Lower Reese River Valley Hydrographic Area } \\
\hline Bare soil & 7,600 & 2,360 & 0.15 & 0.15 & 1,140 & 350 \\
\hline \multicolumn{7}{|l|}{ Plant cover: } \\
\hline Less than 10 percent & 76,020 & 44,720 & .24 & .45 & 17,940 & 20,300 \\
\hline At least 10 but less than 20 percent & 5,420 & 40,210 & 1.30 & 1.27 & 7,070 & 50,900 \\
\hline At least 20 but less than 35 percent & 1,230 & 2,990 & 2.15 & 2.15 & 2,650 & 6,420 \\
\hline At least 35 but less than 50 percent & 550 & 520 & 2.51 & 2.49 & 1,380 & 1,300 \\
\hline At least 50 percent & 210 & 160 & 2.58 & 2.59 & 540 & 410 \\
\hline Estimated total annual ground-water $\mathrm{ET}^{3} \ldots$ & .............. & ........... & ............. & .................. & 30,700 & 79,800 \\
\hline Open-water bodies & 129 & 185 & 4.2 & 4.2 & 540 & 780 \\
\hline \multicolumn{7}{|c|}{ Whirlwind Valley Hydrographic Area } \\
\hline Bare soil & 730 & 740 & 0.15 & 0.15 & 110 & 110 \\
\hline \multicolumn{7}{|l|}{ Plant cover: } \\
\hline Less than 10 percent & 4,220 & 3,010 & .35 & .38 & 1,470 & 1,160 \\
\hline At least 10 but less than 20 percent & 3,220 & 3,510 & 1.40 & 1.44 & 4,520 & 5,050 \\
\hline At least 20 but less than 35 percent & 2,080 & 2,830 & 2.18 & 2.16 & 4,540 & 6,120 \\
\hline At least 35 but less than 50 percent & 870 & 940 & 2.50 & 2.50 & 2,180 & 2,350 \\
\hline At least 50 percent & 410 & 480 & 2.58 & 2.59 & 1,060 & 1,240 \\
\hline Estimated total annual ground-water $\mathrm{ET}^{3} \ldots$ & .......... & & & ................. & 13,900 & 16,000 \\
\hline Open-water bodies & 16 & 34 & 4.2 & 4.2 & 70 & 140 \\
\hline
\end{tabular}


Table 6. Average annual evapotranspiration rates from areas of bare soil or phreatophyte vegetation, evaporation rates from open water, and annual volume of ground-water evapotranspiration from valley lowlands, 1989 and 1995, in the 14 hydrographic areas of middle Humboldt River Basin, north-central Nevada-Continued

\begin{tabular}{|c|c|c|c|c|c|c|}
\hline \multirow{3}{*}{ Zone } & \multirow{2}{*}{\multicolumn{2}{|c|}{$\begin{array}{l}\text { Area }^{1} \\
\text { (acres) }\end{array}$}} & \multicolumn{4}{|c|}{ Average evapotranspiration ${ }^{2}$} \\
\hline & & & \multicolumn{2}{|c|}{$\begin{array}{c}\text { Rate } \\
\text { (feet per year) }\end{array}$} & \multicolumn{2}{|c|}{$\begin{array}{c}\text { Volume } \\
\text { (acre-feet per year) }\end{array}$} \\
\hline & 1989 & 1995 & 1989 & 1995 & 1989 & 1995 \\
\hline \multicolumn{7}{|c|}{ Boulder Flat Hydrographic Area } \\
\hline Bare soil & 670 & 890 & 0.15 & 0.15 & 100 & 130 \\
\hline \multicolumn{7}{|l|}{ Plant cover: } \\
\hline Less than 10 percent & 56,450 & 12,700 & .44 & .56 & 25,060 & 7,100 \\
\hline At least 10 but less than 20 percent & 24,570 & 56,240 & 1.38 & 1.47 & 33,830 & 82,900 \\
\hline At least 20 but less than 35 percent & 10,820 & 22,970 & 2.15 & 2.11 & 23,240 & 48,510 \\
\hline At least 35 but less than 50 percent & 2,950 & 2,870 & 2.50 & 2.49 & 7,370 & 7,140 \\
\hline At least 50 percent & 950 & 620 & 2.59 & 2.59 & 2,460 & 1,600 \\
\hline Estimated total annual ground-water $\mathrm{ET}^{3} \ldots$ & ........ & .......... & (n........ & 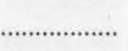 & 92,100 & 147,400 \\
\hline Open-water bodies & 108 & 243 & 4.2 & 4.2 & 450 & 1,000 \\
\hline \multicolumn{7}{|c|}{ Rock Creek Valley Hydrographic Area } \\
\hline Bare soil & 10 & 0 & 0.15 & 0.15 & 0 & 0 \\
\hline \multicolumn{7}{|l|}{ Plant cover: } \\
\hline Less than 10 percent & 6,830 & 670 & .59 & .73 & 4,020 & 490 \\
\hline At least 10 but less than 20 percent & 2,730 & 8,250 & 1.19 & 1.40 & 3,240 & 11,530 \\
\hline At least 20 but less than 35 percent & 200 & 880 & 2.18 & 2.07 & 440 & 1,820 \\
\hline At least 35 but less than 50 percent & 40 & 50 & 2.51 & 2.49 & 100 & 120 \\
\hline At least 50 percent & 10 & 0 & 2.58 & 2.58 & 30 & 0 \\
\hline Estimated total annual ground-water $\mathrm{ET}^{3} \ldots$ & . & 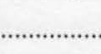 & $\ldots$ & .......... & 7,800 & 14,000 \\
\hline Open-water bodies & 0 & 0 & 4.2 & 4.2 & 0 & 0 \\
\hline \multicolumn{7}{|c|}{ Willow Creek Valley Hydrographic Area } \\
\hline Bare soil & 30 & 20 & 0.15 & 0.15 & 0 & 0 \\
\hline \multicolumn{7}{|l|}{ Plant cover: } \\
\hline Less than 10 percent & 840 & 140 & .68 & .48 & 570 & 70 \\
\hline At least 10 but less than 20 percent & 5,000 & 4,260 & 1.37 & 1.60 & 6,860 & 6,810 \\
\hline At least 20 but less than 35 percent & 2,130 & 3,290 & 2.20 & 2.14 & 4,680 & 7,060 \\
\hline At least 35 but less than 50 percent & 1,920 & 1,780 & 2.51 & 2.51 & 4,820 & 4,470 \\
\hline At least 50 percent & 880 & 1,310 & 2.58 & 2.59 & 2,270 & 3,390 \\
\hline Estimated total annual ground-water $\mathrm{ET}^{3} \ldots$ & 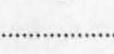 & 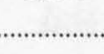 & ............... & $\ldots \ldots \ldots$ & 19,200 & 21,800 \\
\hline Open-water bodies & 2 & 3 & 4.2 & 4.2 & 10 & 10 \\
\hline \multicolumn{7}{|c|}{ Clovers Area } \\
\hline Bare soil & 11,340 & 4,670 & 0.15 & 0.15 & 1,700 & 700 \\
\hline \multicolumn{7}{|l|}{ Plant cover: } \\
\hline Less than 10 percent & 94,210 & 59,120 & .21 & .50 & 20,160 & 29,500 \\
\hline At least 10 but less than 20 percent & 6,980 & 49,470 & 1.38 & 1.21 & 9,600 & 60,060 \\
\hline At least 20 but less than 35 percent & 6,110 & 7,070 & 2.21 & 2.14 & 13,480 & 15,100 \\
\hline At least 35 but less than 50 percent & 2,990 & 1,050 & 2.50 & 2.49 & 7,470 & 2,610 \\
\hline At least 50 percent & 570 & 100 & 2.58 & 2.58 & 1,470 & 260 \\
\hline Estimated total annual ground-water $\mathrm{ET}^{3} \ldots$ & $\ldots \ldots \ldots . . . . .$. & ............... & ................. & 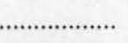 & 53,900 & 108,200 \\
\hline Open-water bodies & 125 & 849 & 4.2 & 4.2 & 520 & 3,570 \\
\hline
\end{tabular}


Table 6. Average annual evapotranspiration rates from areas of bare soil or phreatophyte vegetation, evaporation rates from open water, and annual volume of ground-water evapotranspiration from valley lowlands, 1989 and 1995 , in the 14 hydrographic areas of middle Humboldt River Basin, north-central Nevada-Continued

\begin{tabular}{|c|c|c|c|c|c|c|}
\hline \multirow{3}{*}{ Zone } & \multirow{2}{*}{\multicolumn{2}{|c|}{$\begin{array}{l}\text { Area }^{1} \\
\text { (acres) }\end{array}$}} & \multicolumn{4}{|c|}{ Average evapotranspiration ${ }^{2}$} \\
\hline & & & \multicolumn{2}{|c|}{$\begin{array}{c}\text { Rate } \\
\text { (feet per year) }\end{array}$} & \multicolumn{2}{|c|}{$\begin{array}{c}\text { Volume } \\
\text { (acre-feet per year) }\end{array}$} \\
\hline & 1989 & 1995 & 1989 & 1995 & 1989 & 1995 \\
\hline \multicolumn{7}{|c|}{ Pumpernickel Valley Hydrographic Area } \\
\hline Bare soil & 6,820 & 3,140 & 0.15 & 0.15 & 1,020 & 470 \\
\hline \multicolumn{7}{|l|}{ Plant cover: } \\
\hline Less than 10 percent & 26,520 & 19,520 & .13 & .35 & 3,450 & 6,830 \\
\hline At least 10 but less than 20 percent & 4,480 & 15,210 & 1.44 & 1.34 & 6,450 & 20,380 \\
\hline At least 20 but less than 35 percent & 3,680 & 3,830 & 2.18 & 2.14 & 8,020 & 8,200 \\
\hline At least 35 but less than 50 percent & 780 & 490 & 2.49 & 2.48 & 1,940 & 1,220 \\
\hline At least 50 percent & 80 & 30 & 2.58 & 2.58 & 210 & 80 \\
\hline \multicolumn{3}{|c|}{ Estimated total annual ground-water $\mathrm{ET}^{3}}$. & .............. & .............. & 21,100 & 37,200 \\
\hline Open-water bodies & 99 & 242 & 4.2 & 4.2 & 420 & 1,020 \\
\hline \multicolumn{7}{|c|}{ Kelly Creek Area } \\
\hline Bare soil & 2,200 & 780 & 0.15 & 0.15 & 330 & 120 \\
\hline \multicolumn{7}{|l|}{ Plant cover: } \\
\hline Less than 10 percent & 33,420 & 20,680 & .17 & .50 & 5,680 & 10,340 \\
\hline At least 10 but less than 20 percent & 2,210 & 16,180 & 1.39 & 1.23 & 3,070 & 19,900 \\
\hline At least 20 but less than 35 percent & 1,900 & 2,020 & 2.18 & 2.15 & 4,140 & 4,340 \\
\hline At least 35 but less than 50 percent & 400 & 450 & 2.49 & 2.49 & 1,000 & 1,120 \\
\hline At least 50 percent & 120 & 40 & 2.58 & 2.58 & 310 & 100 \\
\hline \multicolumn{3}{|c|}{ Estimated total annual ground-water $\mathrm{ET}^{3}$... } & & ........ & 14,500 & 35,900 \\
\hline Open-water bodies & 2 & 93 & 4.2 & 4.2 & 10 & 390 \\
\hline
\end{tabular}

\section{Discussion of Water-Budget Estimates}

The preceding methods applied to the hydrographic areas resulted in water budgets that represent average annual conditions over the period $1961-90$ and do not account for ground-water pumping. Although the newly estimated water budgets are subject to a number of qualifications and uncertainties, they illustrate the relative distribution and movement of water in the hydrographic areas. Components of inflow and outflow estimated for the 14 hydrographic areas are presented in tables 7 through 20 . Some budget components are presented as a range based on two sets of data collected at different times. The range in values illustrates the uncertainty in estimating water-budget components, some of which may be due to climatic variability. The distribution of estimated average annual precipitation and of landforms in the 14 hydrographic areas is presented in figures 4 through 17 .

On average, total annual inflow to the middle Humboldt River basin is estimated to be about 5,000,000 acre-ft. Of the total inflow, 4,600,000 acre-ft is from precipitation that falls in the 14 hydrographic areas, and about 350,000 acre- $\mathrm{ft}$ is inflow from the Humboldt River. Average annual outflow is estimated to be about 5,100,000 acre-ft, of which ET accounts for about 4,800,000 acre-ft. Average annual outflow of the Humboldt River is about 300,000 acre- $\mathrm{ft}$. The imbalance between estimates of inflow and outflow is about 100,000 acre-ft per year, a difference of about 2 percent. 
Upper Reese River Valley Hydrographic Area has the largest water budget; the estimated annual inflow is 803,000 acre-ft, and outflow, is 744,000 to 794,000 acre- $\mathrm{ft}$ (table 10). The smallest water budget is for Whirlwind Valley Hydrographic Area, where the estimated inflow is 55,000 acre-ft per year and outflow is 66,000 to 68,000 acre- $\mathrm{ft}$ per year, if Humboldt River flow is ignored (table 14). The greatest water-budget imbalance among the 14 areas is for Boulder Flat Hydrographic Area (table 15). Estimated annual outflow is 55,000 to 112,000 acre- $\mathrm{ft}$ greater than inflow, due in part to the additional availability of Humboldt River water for ET.

Generally, for hydrographic areas of the Humboldt River valley where the river makes up part of the area boundary or transverses the area (Boulder Flat, Crescent Valley, Whirlwind Valley, Lower Reese River Valley, Clovers Area, Pumpernickel Valley, and Kelly Creek Area) estimates of outflow are greater than estimates of inflow (fig. 18A); Total ET in these areas represents more than 97 percent of the total outflow. Due to insufficient data about surface- and groundwater flow at hydrographic-area boundaries, contribution to ET from the Humboldt River was not included in the water budgets. River water that has infiltrated upstream and moves parallel to the river is available to phreatophyte vegetation downstream. Regional analyses of ground-water ET based on Landsat TM data cannot be used to distinguish the source of ground water consumed by phreatophyte vegetation, particularly in areas where inflow components cannot be quantified. Because of the unaccounted river water consumed by phreatophyte vegetation in these seven areas, outflow is greater than inflow. Except for Rock Creek Valley and Willow Creek Valley Hydrographic Areas, the remaining areas whose boundaries do not include the Humboldt River valley have inflow estimates within range of estimated outflow or slightly greater (fig. $18 A)$.

Surface-water outflow from Rock Creek Valley and Willow Creek Valley represent 12 and 6 percent of the total outflow, respectively, from these hydrographic areas. The mountain block makes up nearly 75 percent of the total drainage area (table 3 ) and consequently receives the greatest proportion of annual precipitation. Both of these characteristics are conducive to runoff generation, which results in slightly greater outflow than inflow (fig. 18).
Estimated ground-water budgets for the 14 hydrographic areas are summarized in table 21 . Groundwater inflow to an area consists of ground-water recharge that originates within the hydrographic area as either precipitation or runoff and subsurface inflow from adjacent areas. Data necessary to estimate interbasin flow may not be available or may be insufficient. In areas where interbasin flow was estimated, the flow represents 3 to 47 percent of the total inflow (table 21). However, more detailed analysis in each hydrographic area is needed to evaluate this component of the water budget more completely.

Estimates of ground-water recharge based on mass-balance calculations were simplified into three components on the basis of recharge processes and locations where recharge takes place (table 21 and fig. $3)$. On average, about 70 percent of total ground-water recharge in the 14 hydrographic areas occurs in the mountain block. The remaining 25 to 30 percent occurs from infiltration of runoff on piedmont-slope areas. Ground-water recharge from direct precipitation on piedmont slopes is small and estimated to be negligible in eight of the hydrographic areas. Estimates of groundwater recharge based on the revised Maxey-Eakin coefficients (eq. 3) generally agree with the mass-balance calculations (table 21).

For hydrographic areas not influenced by the Humboldt River ground-water ET estimates range from 1 to about 8 percent of the total annual precipitation. Ground-water inflow generally is greater than outflow for those areas (fig. 18). For the seven hydrographic areas that the river either bounds or transverses, ET estimates range from 9 to more than 48 percent of the total annual precipitation and ground-water outflow is greater than inflow (fig. 18). Consequently, the Humboldt River may provide as much as 40 percent of the water for ground-water ET.

\section{Comparison of Previous Water Budgets}

Eakin and Lamke (1966) provided the most comprehensive study for making comparisons of water budgets for the 14 hydrographic areas discussed in this report. The generalized budgets presented by Eakin and Lamke (1966, p. 11) represent average conditions for the 1912-63 reference period, whereas budgets presented in this report represent average annual conditions for the 1961-90 reference period. 
Average annual precipitation for 1912-63 was 6 to 19 percent less than that for 1961-90, based on data from four long-term weather stations in the Humboldt River Basin (at Austin, Battle Mountain, Elko, and Lovelock; fig. 1). The distribution of annual precipitation used in most of the earlier studies of the Humboldt River Basin, including the reconnaissance study by Eakin and Lamke (1966), was estimated by Hardman and Mason (1949). The Hardman and Mason precipitation map was developed from weather records and other data collected over several decades, through 1936 (Hardman and Mason, 1949, p. 13) and correlated with data on altitude and topography, latitude, and vegetation type. The PRISM-simulated precipitation distribution was derived from 30 years of weather-station data (1961-90) collected throughout Nevada. Dettinger and Schaefer (1995, p. 195) suggested that since the 1960's north-central Nevada has experienced wetter-than-normal conditions due to greater variation in summertime precipitation. This wetter-than-normal period was preceded by drier-than-normal or near-normal conditions from the 1920's through the 1950's.

Because the 14 hydrographic areas were grouped into only 8 areas (or subareas) by Eakin and Lamke (1966, p. 32), direct comparison of water budgets between individual hydrographic areas is not entirely possible. For easier comparison, the budget estimates for the 14 hydrographic areas presented herein were grouped in the same manner: subarea 5 corresponds to Pine Valley; subarea 6, to Carico Lake Valley and Crescent Valley; subarea 7, to Rock Creek Valley and Willow Creek Valley; subarea 8, to Boulder Flat; subarea 9, to Upper Reese River Valley; subarea 10, to Antelope Valley and Middle Reese River Valley; subarea 11, the Lower Reese River Valley, Buffalo Valley, and Whirlwind Valley; and subarea 12, to Pumpernickel Valley, Clovers Area, and Kelly Creek Area. Subarea 11 also includes Buffalo Valley, but because it is not part of the middle Humboldt River Basin as defined by the current study, subarea 12 is not considered in the comparison.

Although whether the boundaries of the 14 hydrographic areas that make up the 8 subareas as defined by Eakin and Lamke (1966) are totally consistent with those used in this study, some general comparisons can be made. Average annual precipitation in each subarea for 1961-90 was 5 to 28 percent greater than that estimated for 1912-63 (Eakin and Lamke, 1966, p. 58). The greatest difference is in the valleys of each subarea.
The term "valley areas," as used by Eakin and Lamke (1966, p. 58), was assumed to be similar to the combined areas of piedmont slope and valley lowland as described in this report. In all subareas except subarea 7 (Rock Creek Valley and Willow Creek Valley), the valley areas receive as much as or more than the total annual precipitation of the mountain-block areas (table 3). This precipitation pattern is due, in part, to the relatively large valley areas, which typically make up more than 50 percent of the total drainage area of a hydrographic area.

The annual volume of ET estimated in each subarea is 2 to nearly 34 percent greater than estimated by Eakin and Lamke (1966, p. 59), although the percentage of annual precipitation lost to ET is similar. In general, less ET was estimated in mountain-block areas and considerably more in valley areas compared to the earlier study. Mountain-block ET was estimated indirectly as the residual between annual precipitation and water yield in both studies. In most subareas, water yields (table 4) were greater than the estimates made by Eakin and Lamke (1966, p. 58); the higher values resulted in lower estimated ET in the mountain block (table 4). About 15 percent of the total precipitation in mountain-block areas was assumed to become a component of water yield (either ground water or runoff), whereas Eakin and Lamke (1966, p. 58) had estimated this component to have been only 11 percent. The larger estimates of water yield from the mountain blocks resulted in greater ground-water recharge because runoff was nearly the same in both estimates.

Mass-balance calculations of ground-water recharge (table 21) were on average about 45 percent greater than previous estimates (Eakin, 1961; Zones, 1961; Crosthwaite, 1963; Eakin and others, 1965; Everett and Rush, 1966; Olmsted and Rush, 1987; and Maurer and others, 1996). For most areas, recharge estimates derived from the revised Maxey-Eakin method (eq. 3); parenthetic value shown in table 21 is within the range of recharge estimated from mass-balance calculations. However, the two methods used to estimate ground-water recharge are not entirely independent because both methods are functions of the distribution and quantity of the same precipitation data set. Whether the estimated increase in ground-water recharge is the result of greater precipitation or the result caused by assumptions used in estimating recharge is uncertain. 
Table 7. Average annual water budgets for Pine Valley Hydrographic Area, middle Humboldt River Basin, north-central Nevada

[Bold symbols in parentheses correspond to those used in table 2 and fig. 3. Values for separate flow components rounded to nearest 100 acre-feet per year; totals rounded to nearest 1,000 acre-feet per year. ET, evapotranspiration. - , no data or not applicable]

\begin{tabular}{|c|c|c|}
\hline Water-budget components & $\begin{array}{c}\text { Inflow } \\
\text { (acre-feet } \\
\text { per year) }\end{array}$ & $\begin{array}{c}\text { Outflow } \\
\text { (acre-feet } \\
\text { per year) }\end{array}$ \\
\hline \multicolumn{3}{|l|}{ Mountain-block water budget } \\
\hline \multicolumn{3}{|l|}{ Inflow: } \\
\hline Precipitation on mountain block $(P \mathrm{mb})^{1}$ & 326,400 & - \\
\hline $\begin{array}{l}\text { Subsurface flow from adjacent hydrographic areas to bedrock aquifer (SFin) } \\
\text { Outflow }\end{array}$ & - & - \\
\hline \multicolumn{3}{|l|}{ Outflow: } \\
\hline $\begin{array}{l}\text { Runoff from mountain block to piedmont slope (ROmb) } \\
\text { Subsurface flow from bedrock aquifer in mountain block to basin-fill aquifer beneath piedmont slope (SFmb) }\end{array}$ & - & 22,400 \\
\hline $\begin{array}{l}\text { Subsurface flow from bedrock aquifer in mountain block to basin-fill aquifer beneath piedmont slope (SFmb) } \\
\text { Subsurface flow from mountain block to adjacent hydrographic areas (SFout) }\end{array}$ & - & 38,200 \\
\hline $\begin{array}{l}\text { Subsurface flow from mountain block to adjacent hydrographic areas (SFout) } \\
\text { ET and sublimation of precipitation and soil moisture and ET from riparian areas (ETmb) }\end{array}$ & - & - \\
\hline ET and sublimation of precipitation and soil moisture and ET from riparian areas (ETmb) ${ }^{2}$ & - & 265,800 \\
\hline Total................................ & 326,000 & 326,000 \\
\hline \multicolumn{3}{|l|}{ Piedmont-slope water budget } \\
\hline \multicolumn{3}{|l|}{ Inflow: } \\
\hline Precipitation on piedmont slope (Pps) ${ }^{1}$ & 333,800 & - \\
\hline Runoff from mountain block to piedmont slope $(\mathrm{ROmb})^{2}$ & 22,300 & - \\
\hline Surface-water flow from adjacent hydrographic areas (SWin) & 0 & - \\
\hline Subsurface flow from bedrock aquifer in mountain block to basin-fill aquifer beneath piedmont slope (SFmb) ${ }^{2}$ & 38,300 & - \\
\hline Subsurface flow from adjacent hydrographic areas (SFin) & - & - \\
\hline \multicolumn{3}{|l|}{ Outflow: } \\
\hline Runoff generated on piedmont slope (ROps) ${ }^{3}$ & - & $0-2,500$ \\
\hline Subsurface flow from basin-fill aquifer beneath piedmont slope to basin-fill aquifer beneath valley lowland (SFps) ${ }^{3}$ & - & $52,500-79,300$ \\
\hline Subsurface flow from basin-fill aquifer beneath piedmont slope to adjacent hydrographic areas (SFout) & - & - \\
\hline ET and sublimation of precipitation and soil moisture (ETps) ${ }^{3}$ & - & $306,300-333,800$ \\
\hline \multirow[t]{2}{*}{ ET from vegetated flood plains (ETrps) ${ }^{3}$} & - & $3,200-4,100$ \\
\hline & 394,000 & $362,000-420,000$ \\
\hline
\end{tabular}

Valley-lowland water budget

Inflow:

Precipitation on valley lowland $(\mathrm{PV})^{1}$

Runoff from piedmont slope to valley lowland (ROps) $)^{3}$

Surface-water flow from adjacent hydrographic areas (SWin)

Subsurface flow from basin-fill aquifer beneath piedmont slope to basin-fill aquifer beneath valley lowland (SFps) ${ }^{3} \quad 52,500-79,300$

Subsurface flow from adjacent hydrographic areas (SFin)

Outflow:

Runoff generated on valley lowland (ROvi)

Subsurface flow from basin-fill aquifer beneath valley lowland to adjacent hydrographic areas (SFv)

ET of precipitation and soil moisture (ETVI)

ET of ground water from valley lowland (ETgw $)^{5}$

Evaporation from open-water bodies (Esw)

Total......

Pine Valley Hydrographic Area water budget

\section{Inflow:}

Precipitation in Pine Valley Hydrographic Area (Pmb, Pps, Pvl)

Surface-water flow from adjacent hydrographic areas (SWin)

Subsurface flow from adjacent hydrographic areas (SFin)

Outflow:

Surface-water flow from Pine Valley Hydrographic Area at hydrographic-area boundary (SWtot)

Subsurface flow from Pine Valley Hydrographic Area at hydrographic-area boundary (SFtot)

ET and sublimation from Pine Valley Hydrographic Area (ETmb, ETps, ETrps, ETV, ETgw, Esw)

\section{Total}

\begin{tabular}{|c|c|c|}
\hline & $\begin{array}{c}688,000 \\
0 \\
0\end{array}$ & - \\
\hline Wtot) & - & $\begin{array}{c}68,100 \\
79,300 \\
642,700-681,900 \\
\end{array}$ \\
\hline tal............................. & 688,000 & $660,000-699,000$ \\
\hline
\end{tabular}

\footnotetext{
'See table 3.

${ }^{2}$ See table 4.

${ }^{3}$ See table 5 .

${ }^{4}$ Eakin $(1961$, p. 24).

${ }^{5}$ See table 6.

${ }^{6}$ Derived from continuous-stage-recording gage on Pine Creek (1947-58) and adjusted to long-term record at Martin Creek (1922-95).

${ }^{7}$ Combined values: 9,000 acre-feet per year estimated by Harrill (1968, p. 26) to exit from Garden Valley, subbasin in southeastern part of Pine Valley Hydrographic Area, and additional 300 acre-feet per year estimated by Eakin $(1961$, p. 24) to exit Pine Valley beneath north hydrographic-area boundary. Because assignment to landform is uncertain, this subsurface flow is accounted for only in overall hydrographic-area budget.
} 
Table 8. Average annual water budgets for Crescent Valley Hydrographic Area, middle Humboldt River Basin, north-central Nevada

[Bold symbols in parentheses correspond to those used in table 2 and fig. 3. Values for separate flow components rounded to nearest 100 acre-feet per year; totals rounded to nearest 1,000 acre-feet per year. ET, evapotranspiration. -, no data or not applicable]

Water-budget components

Inflow

(acre-feet

per year)
Outflow

(acre-feet per year)

Mountain-block water budget

Inflow:

Precipitation on mountain block (Pmb) ${ }^{1}$

Subsurface flow from adjacent hydrographic areas to bedrock aquifer (SFin)

Outflow:

Runoff from mountain block to piedmont slope (ROmb) ${ }^{2}$

Subsurface flow from bedrock aquifer in mountain block to basin-fill aquifer beneath piedmont slope (SFmb) ${ }^{2}$

Subsurface flow from mountain block to adjacent hydrographic areas (SFout)

ET and sublimation of precipitation and soil moisture and ET from riparian areas (ETmb) ${ }^{2}$

\begin{tabular}{ccc}
184,100 & - \\
& - & - \\
& - & 7,000 \\
Total......................... & - & 18,200 \\
\cline { 2 - 3 } & - & - \\
& 184,000 & 158,900 \\
\hline
\end{tabular}

Piedmont-slope water budget

Inflow:

Precipitation on piedmont slope (Pps) ${ }^{1}$

Runoff from mountain block to piedmont slope (ROmb) ${ }^{2}$

Surface-water flow from adjacent hydrographic areas (SWin)

Subsurface flow from bedrock aquifer in mountain block to basin-fill aquifer beneath piedmont slope (SFmb) ${ }^{2}$

Subsurface flow from adjacent hydrographic areas (SFin)

Outflow:

Runoff generated on piedmont slope (ROps) ${ }^{5}$

Subsurface flow from basin-fill aquifer beneath piedmont slope to basin-fill aquifer beneath valley lowland (SFps) ${ }^{5}$

Subsurface flow from basin-fill aquifer beneath piedmont slope to adjacent hydrographic areas (SFout)

ET and sublimation of precipitation and soil moisture (ETPs) ${ }^{5}$

ET from vegetated flood plains (ETrps) ${ }^{5}$

Total.

196,700
7,000
$3200-300$
18,200
${ }^{4} 300$

$-$

-

-

-

$0-800$

$25,500-26,500$

$-$

$196,000-196,700$

$500-1,900$

$222,000-226,000$

Valley-lowland water budget

Inflow:

Precipitation on valley lowland (Pv) ${ }^{1}$

Runoff from piedmont slope to valley lowland (ROps) ${ }^{5}$

Surface-water flow from adjacent hydrographic areas (SWin)

Subsurface flow from basin-fill aquifer beneath piedmont slope to basin-fill aquifer beneath valley lowland (SFps) ${ }^{5}$

Subsurface flow from adjacent hydrographic areas (SFin)

Outflow:

Runoff generated on valley lowland (ROVl)

Subsurface flow from basin-fill aquifer beneath valley lowland to adjacent hydrographic areas (SFv)

ET of precipitation and soil moisture (ETVI)

ET of ground water from valley lowland (ETgw) ${ }^{7}$

Evaporation from open-water bodies (Esw) ${ }^{7}$

\begin{tabular}{|c|c|c|}
\hline & $\begin{array}{l}- \\
-\end{array}$ & $\begin{array}{c}65,100 \\
19,600-37,100 \\
400-500\end{array}$ \\
\hline 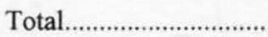 & $91,000-92,000$ & $85,000-103,000$ \\
\hline
\end{tabular}

Crescent Valley Valley Hydrographic Area water budget

Inflow:

Precipitation in Crescent Valley Hydrographic Area (Pmb, Pps, Pvl)

Surface-water flow from adjacent hydrographic areas (SWin)

Subsurface flow from adjacent hydrographic areas (SFin)

Outflow:

Surface-water flow from Crescent Valley Hydrographic Area at hydrographic-area boundary (swtot)

Subsurface flow from Crescent Valley Hydrographic Area at hydrographic-area boundary (SFtot)

ET and sublimation from Crescent Valley Hydrographic Area (ETmb, ETps, ETrps, ETV, ETgw, Esw)

Total.

\begin{tabular}{cc}
${ }^{446,000}$ & - \\
${ }^{8} 200-300$ & - \\
${ }^{9} 700$ & - \\
- & ${ }^{10} 1,000$ \\
- & $6<300$ \\
- & $\frac{440,500-460,200}{442,000-461,000}$ \\
\cline { 1 - 1 } &
\end{tabular}

1 See table 3.

${ }^{2}$ See table 4.

${ }^{3}$ Zones (1961, p. 20)

${ }^{4}$ Everett and Rush (1966, p. 17)

${ }^{5}$ See table 5.

${ }^{6}$ Zones $(1961$, p. 23)

7 See table 6.

${ }^{8}$ Zones (1961, p. 20).

${ }^{9}$ Combined values: 300 acre-feet per year estimated by Everett and Rush (1966, p. 17) to enter from Carico Lake Valley Hydrographic Area and additional 400 acre-feet per year estimated by Olmsted and Rush (1987, p. 32) to enter from Whirlwind Valley Hydrographic Area.

${ }^{10}$ Eakin and Lamke (1966, p. 36). 
[Bold symbols in parentheses correspond to those used in table 2 and fig. 3. Values for separate flow components rounded to nearest 100 acre-feet per year; totals rounded to nearest 1,000 acrefeet per year. ET, evapotranspiration. -, no data or not applicable; <, less than]

\begin{tabular}{|c|c|c|}
\hline Water-budget components & $\begin{array}{c}\text { Inflow } \\
\text { (acre-feet } \\
\text { per year) }\end{array}$ & $\begin{array}{l}\text { Outflow } \\
\text { (acre-feet } \\
\text { per year) }\end{array}$ \\
\hline \multicolumn{3}{|l|}{ Mountain-block water budget } \\
\hline \multicolumn{3}{|l|}{ Inflow: } \\
\hline Precipitation on mountain block $(\mathbf{P m b})^{1}$ & 123,000 & - \\
\hline Subsurface flow from adjacent hydrographic areas to bedrock aquifer (SFin) & - & - \\
\hline \multicolumn{3}{|l|}{ Outflow: } \\
\hline Runoff from mountain block to piedmont slope $(\mathrm{RO} \mathrm{mb})^{2}$ & - & 5,900 \\
\hline Subsurface flow from bedrock aquifer in mountain block to basin-fill aquifer beneath piedmont slope (SFmb) ${ }^{2}$ & - & 13,000 \\
\hline Subsurface flow from mountain block to adjacent hydrographic areas (SFout) & - & - \\
\hline ET and sublimation of precipitation and soil moisture and ET from riparian areas (ETmb) ${ }^{2}$ & - & 104,100 \\
\hline Total................................... & 123,000 & 123,000 \\
\hline \multicolumn{3}{|l|}{ Piedmont-slope water budget } \\
\hline \multicolumn{3}{|l|}{ Inflow: } \\
\hline Precipitation on piedmont slope (Pps) $)^{1}$ & 107,600 & - \\
\hline Runoff from mountain block to piedmont slope $(\mathrm{RO} \mathrm{mb})^{2}$ & 5,900 & - \\
\hline Surface-water flow from adjacent hydrographic areas (SWin) & 0 & - \\
\hline Subsurface flow from bedrock aquifer in mountain block to basin-fill aquifer beneath piedmont slope (SFmb) ${ }^{2}$ & 13,000 & - \\
\hline Subsurface flow from Upper Reese River Valley Hydrographic Area to basin-fill aquifer beneath piedmont slope (SFin) & ${ }^{3} 3,000$ & - \\
\hline \multicolumn{3}{|l|}{ Outflow: } \\
\hline Runoff generated on piedmont slope (ROps) ${ }^{4}$ & - & $0-700$ \\
\hline Subsurface flow from basin-fill aquifer beneath piedmont slope to basin-fill aquifer beneath valley lowland (SFps) ${ }^{4}$ & - & $21,700-23,400$ \\
\hline Subsurface flow from basin-fill aquifer beneath piedmont slope to adjacent hydrographic areas (SFout) & - & - \\
\hline ET and sublimation of precipitation and soil moisture (ETps) ${ }^{4}$ & - & $105,400-107,600$ \\
\hline \multirow{2}{*}{ ET from vegetated flood plains (ETrps) } & - & $1,100-1,200$ \\
\hline & 130,000 & $128,000-133,000$ \\
\hline \multicolumn{3}{|l|}{ Valley-lowland water budget } \\
\hline \multicolumn{3}{|l|}{ Inflow: } \\
\hline Precipitation on valley lowland (Pvl $)^{1}$ & 8,100 & - \\
\hline Runoff from piedmont slope to valley lowland (ROps) ${ }^{4}$ & $0-700$ & - \\
\hline Surface-water flow from adjacent hydrographic areas (SWin) & 0 & - \\
\hline Subsurface flow from basin-fill aquifer beneath piedmont slope to basin-fill aquifer beneath valley lowland (SFps) ${ }^{4}$ & $21,700-23,400$ & - , \\
\hline Subsurface flow from adjacent hydrographic areas (SFin) & - & - \\
\hline \multicolumn{3}{|l|}{ Outflow: } \\
\hline Runoff generated on valley lowland (ROvi) & - & 0 \\
\hline Subsurface flow from basin-fill aquifer beneath valley lowland to Crescent Valley Hydrographic Area (SFvi) & - & ${ }^{6}<300$ \\
\hline ET of precipitation and soil moisture (ETVI) & - & 8,100 \\
\hline ET of ground water from valley lowland $(\mathrm{ETgw})^{5}$ & - & $4,800-9,600$ \\
\hline \multirow[t]{2}{*}{ Evaporation from open-water bodies (Esw) } & - & 0 \\
\hline & $30,000-32,000$ & $13,000-18,000$ \\
\hline
\end{tabular}

Carico Lake Valley Hydrographic Area water budget

Inflow:

Precipitation in Carico Lake Valley Hydrographic Area (Pmb, Pps, Pvl)

Surface-water flow from adjacent hydrographic areas (SWin)

Subsurface flow from adjacent hydrographic areas (SFIn)

Outflow:

Surface-water flow from Carico Lake Valley Hydrographic Area at hydrographic-area boundary (SWtot)

Subsurface flow from Carico Lake Valley Hydrographic Area at hydrographic-area boundary (SFtot)

ET and sublimation from Carico Lake Valley Hydrographic Area (ETmb, ETps, ETrps, ETV, ETgw, Esw)

Total........

\begin{tabular}{|c|c|}
\hline $\begin{array}{c}239,000 \\
0 \\
33,000\end{array}$ & $\begin{array}{l}- \\
-\end{array}$ \\
\hline - & ${ }^{7} 200-300$ \\
\hline - & $\begin{array}{c}{ }^{0}<300 \\
223,500-230,600\end{array}$ \\
\hline 242,000 & $224,000-231,000$ \\
\hline
\end{tabular}

\footnotetext{
${ }^{1}$ See table 3.

${ }^{2}$ See table 4 .

${ }^{3}$ Estimated from equation 4 (see text).

${ }^{4}$ See table 5 .

${ }^{5}$ See table 6.

${ }^{6}$ Everett and Rush (1966, p. 17).

${ }^{7}$ Zones (1961, p. 20).
} 
Table 10. Average annual water budgets for Upper Reese River Valley Hydrographic Area, middle Humboldt River Basin, north-central Nevada

[Bold symbols in parentheses correspond to those used in table 1 and fig. 3. Values for separate flow components rounded to nearest 100 acre-feet per year; totals rounded to nearest 1,000 acrefeet per year. ET, evapotranspiration. - , no data or not applicable]

Water-budget components

Mountain-block water budget

Inflow:

Precipitation on mountain block $(\mathrm{Pmb})^{1}$

Subsurface flow from adjacent hydrographic areas to bedrock aquifer (SFin)

Outflow:

Runoff from mountain block to piedmont slope (ROmb) ${ }^{2}$

Subsurface flow from bedrock aquifer in mountain block to basin-fill aquifer beneath piedmont slope (SFmb) ${ }^{2}$

Subsurface flow from mountain block to adjacent hydrographic areas (SFout)

ET and sublimation of precipitation and soil moisture and ET from riparian areas (ETmb) ${ }^{2}$

Total..........

$\begin{array}{cc}\text { Inflow } & \text { Outflow } \\ \text { (acre-feet } & \text { (acre-feet } \\ \text { per year) } & \text { per year) }\end{array}$

per year)

\section{Piedmont-slope water budget}

Inflow:

Precipitation on piedmont slope (Pps) ${ }^{1}$

Runoff from mountain block to piedmont slope (ROmb) ${ }^{2}$

Surface-water flow from adjacent hydrographic areas (SWin)

Subsurface flow from bedrock aquifer in mountain block to basin-fill aquifer beneath piedmont slope (SFmb) ${ }^{2}$

Subsurface flow from adjacent hydrographic areas (SFin)

Outflow:

Runoff generated on piedmont slope (ROps) ${ }^{3}$

Subsurface flow from basin-fill aquifer beneath piedmont slope to basin-fill aquifer beneath valley lowland (SFps) ${ }^{3}$

Subsurface flow from basin-fill aquifer beneath piedmont slope to Carico Lake Valley Hydrographic Area (SFout)

$\mathrm{ET}$ and sublimation of precipitation and soil moisture (ETps) ${ }^{3}$

ET from vegetated flood plains (ETrps) ${ }^{3}$

Total.

\begin{tabular}{|c|c|}
\hline 413,900 & - \\
\hline 0 & - \\
\hline - & 26,600 \\
\hline - & 47,700 \\
\hline- & 339,600 \\
\hline 414,000 & 414,000 \\
\hline
\end{tabular}

Valley-lowland water budget

Inflow:

Precipitation on valley lowland (Pvi) ${ }^{1}$

Runoff from piedmont slope to valley lowland (ROps) ${ }^{3}$

Surface-water flow from adjacent hydrographic areas (SWin)

Subsurface flow from basin-fill aquifer beneath piedmont slope to basin-fill aquifer beneath valley lowland (SFps) ${ }^{3}$

Subsurface flow from adjacent hydrographic areas (SFIn)

Outflow:

Runoff generated on valley lowland (ROW)

Subsurface flow from basin-fill aquifer beneath valley lowland to Middle Reese River Valley Hydrographic Area

ET of precipitation and soil moisture (ETVI)

ET of ground water from valley lowland $(E T g w)^{5}$

Evaporation from open-water bodies (Esw)

Upper Reese River Valley Hydrographic Area water budget

\begin{tabular}{rc}
354,500 & - \\
26,600 & - \\
0 & - \\
47,800 & - \\
0 & $0-3,000$ \\
- & $71,400-110,000$ \\
- & 43,000 \\
- & $308,100-354,500$ \\
- & $10,900-11,700$ \\
\hline- & $393,000-482,000$ \\
\hline 429,000 &
\end{tabular}

Inflow:

Precipitation in Upper Reese River Valley Hydrographic Area (Pmb, Pps, Pv)

Surface-water flow from adjacent hydrographic areas (SWin)

Subsurface flow from adjacent hydrographic areas (SFIn)

Outflow:

Surface-water flow from Upper Reese River Valley Hydrographic Area at hydrographic-area boundary (SWhot)

Subsurface flow from Upper Reese River Valley Hydrographic Area at hydrographic-area boundary (SFtot)

ET and sublimation from Upper Reese River Valley Hydrographic Area (ETmb, ETps, ETrps, ETVl, ETgw, Esw)

Total...

$\begin{array}{cc}35,000 & - \\ 0-3,000 & - \\ 0 & - \\ 71,400-110,000 & - \\ - & -\end{array}$

$-$

-

- $\quad{ }^{6} 500$

35,000

$43,800-45,800$

$\begin{array}{r}43,800-45 \\ -\quad 0-600 \\ \hline\end{array}$

$106,000-148,000 \quad 79,000-83,000$

${ }^{1}$ See table 3.

${ }^{2}$ See table 4.

${ }^{3}$ See table 5 .

${ }^{4}$ Estimated from equation 4 (see text).

${ }^{5}$ See table 6.

${ }^{6}$ Eakin and others (1965, p. 24).

${ }^{7}$ Combined values: 3,000 acre-feet per year to Carico Lake Valley Hydrographic Area, estimated from equation 4 (see text), and less than 500 acre-feet per year to Middle Reese River Valley Hydrographic Area, estimated by Eakin and others (1965). 
Table 11. Average annual water budgets for Antelope Valley Hydrographic Area, middle Humboldt River Basin, north-central Nevada

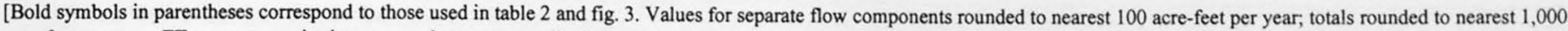
acre-feet per year. ET, evapotranspiration. - , no data or not applicable]

\begin{tabular}{|c|c|c|}
\hline Water-budget components & $\begin{array}{c}\text { Inflow } \\
\text { (acre-feet } \\
\text { per year) }\end{array}$ & $\begin{array}{l}\text { Outflow } \\
\text { (acre-feet } \\
\text { per year) }\end{array}$ \\
\hline \multicolumn{3}{|l|}{ Mountain-block water budget } \\
\hline \multicolumn{3}{|l|}{ Inflow: } \\
\hline Precipitation on mountain block $(\mathrm{Pmb})^{1}$ & 120,200 & - \\
\hline Subsurface flow from adjacent hydrographic areas to bedrock aquifer (SFin) & - & - \\
\hline \multicolumn{3}{|l|}{ Outflow: } \\
\hline Runoff from mountain block to piedmont slope $(\mathrm{ROmb})^{2}$ & - & 5,000 \\
\hline Subsurface flow from bedrock aquifer in mountain block to basin-fill aquifer beneath piedmont slope (SFmb) ${ }^{2}$ & - & 12,200 \\
\hline Subsurface flow from mountain block to adjacent hydrographic areas (SFout) & 一 & - \\
\hline ET and sublimation of precipitation and soil moisture and ET from riparian areas (ETmb $)^{2}$ & - & 103,000 \\
\hline Total............................ & 120,000 & 120,000 \\
\hline
\end{tabular}

Piedmont-slope water budget

Inflow:

Precipitation on piedmont slope (Pps) ${ }^{1}$

Runoff from mountain block to piedmont slope (ROmb) ${ }^{2}$

Surface-water flow from adjacent hydrographic areas (SWin)

Subsurface flow from bedrock aquifer in mountain block to basin-fill aquifer beneath piedmont slope (SFmb) ${ }^{2}$

Subsurface flow from adjacent hydrographic areas (SFin)

Outflow:

Runoff generated on piedmont slope (ROps) ${ }^{3}$

Subsurface flow from basin-fill aquifer beneath piedmont slope to basin-fill aquifer beneath valley lowland (SFps) ${ }^{3}$

Subsurface flow from basin-fill aquifer beneath piedmont slope to adjacent hydrographic areas (SFout)

ET and sublimation of precipitation and soil moisture (ETps) ${ }^{3}$

ET from vegetated flood plains (ETrps) ${ }^{3}$

Total

\begin{tabular}{cc}
134,100 & - \\
5,000 & - \\
0 & - \\
12,200 & - \\
- & $0-600$ \\
- & $17,200-25,200$ \\
- & $127,100-134,100$ \\
- & $200-600$ \\
\hline- & $144,000-160,000$ \\
\hline 151,000 &
\end{tabular}

Valley-lowland water budget

Inflow:

Precipitation on valley lowland (Pv) ${ }^{1}$

Runoff from piedmont slope to valley lowland (ROps) ${ }^{3}$

Surface-water flow from adjacent hydrographic areas (SWin)

Subsurface flow from basin-fill aquifer beneath piedmont slope to basin-fill aquifer beneath valley lowland (SFps) ${ }^{3}$

Subsurface flow from adjacent hydrographic areas (SFin)

Outflow:

Runoff generated on valley lowland (ROvi)

Subsurface flow from basin-fill aquifer beneath valley lowland to Middle Reese River Valley Hydrographic Area (SFvi)

ET of precipitation and soil moisture (ETVI)

ET of ground water from valley lowland (ETgw) ${ }^{5}$

Evaporation from open-water bodies (Esw) ${ }^{5}$

\begin{tabular}{|c|c|c|}
\hline & - & $\begin{array}{c}25,300 \\
2,000-8,400 \\
0\end{array}$ \\
\hline Total............................ & $42,000-51,000$ & $33,000-40,000$ \\
\hline
\end{tabular}

Antelope Valley Hydrographic Area water budget

Inflow:

Precipitation in Antelope Valley Hydrographic Area (Pmb, Pps, Pvi)

Surface-water flow from adjacent hydrographic areas (SWIn)

Subsurface flow from adjacent hydrographic areas (SFin)

Outflow:

Surface-water flow from Antelope Valley Hydrographic Area at hydrographic-area boundary (SWtot)

Subsurface flow from Antelope Valley Hydrographic Area at hydrographic-area boundary (SFtot)

ET and sublimation from Antelope Valley Hydrographic Area (ETmb, ETps, ETrps, ETV, ETgw, Esw)

25,300

$0-600$

0

$17,200-25,200$

$-$

$-$

$-$

$-$

$33,000-40,000$

ET and sublimation from Antelope Valley Hydrographic Area (ETmb, ETps, ETrps, ETM, ETgw, Esw)

\footnotetext{
${ }^{1}$ See table 3.

${ }^{2}$ See table 4.

${ }^{3}$ See table 5 .

${ }^{4}$ Crosthwaite (1963, p. 15). Estimate not supported by recent work (Plume and Ponce, 1999).

${ }^{5}$ See table 6
} 
Table 12. Average annual water budgets for Middle Reese River Valley Hydrographic Area, middle Humboldt River Basin, northcentral Nevada

[Bold symbols in parentheses correspond to those used in table 2 and fig. 3. Values for separate flow components rounded to nearest 100 acre-feet per year; totals rounded to nearest 1,000 acre-feet per year. ET, evapotranspiration. -, no data or not applicable]

\begin{tabular}{|c|c|c|}
\hline Water-budget components & $\begin{array}{l}\text { Inflow } \\
\text { (acre-feet } \\
\text { per year) }\end{array}$ & $\begin{array}{l}\text { Outflow } \\
\text { (acre-feet } \\
\text { per year) }\end{array}$ \\
\hline \multicolumn{3}{|l|}{ Mountain-block water budget } \\
\hline \multicolumn{3}{|l|}{ Inflow: } \\
\hline Precipitation on mountain block $\left(P_{m b}\right)^{1}$ & 110,000 & - \\
\hline Subsurface flow from adjacent hydrographic areas to bedrock aquifer (SFin) & - & - \\
\hline \multicolumn{3}{|l|}{ Outflow: } \\
\hline Runoff from mountain block to piedmont slope $(\mathrm{RO} \mathrm{mb})^{2}$ & - & 3,600 \\
\hline Subsurface flow from bedrock aquifer in mountain block to basin-fill aquifer beneath piedmont slope (SFmb) ${ }^{2}$ & - & 10,200 \\
\hline Subsurface flow from mountain block to adjacent hydrographic areas (SFout) & - & - \\
\hline ET and sublimation of precipitation and soil moisture and ET from riparian areas (ETmb) ${ }^{2}$ & - & 96,200 \\
\hline 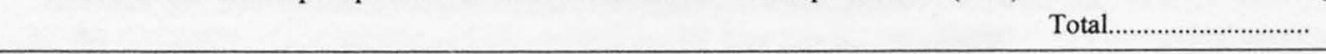 & 110,000 & 110,000 \\
\hline \multicolumn{3}{|l|}{ Piedmont-slope water budget } \\
\hline \multicolumn{3}{|l|}{ Inflow: } \\
\hline Precipitation on piedmont slope (Pps) $)^{1}$ & 46,400 & - \\
\hline Runoff from mountain block to piedmont slope (ROmb) $)^{2}$ & 3,600 & - \\
\hline Surface-water flow from adjacent hydrographic areas (sWin) & 0 & - \\
\hline Subsurface flow from bedrock aquifer in mountain block to basin-fill aquifer beneath piedmont slope (SFmb) ${ }^{2}$ & 10,200 & - \\
\hline Subsurface flow from adjacent hydrographic areas (SFin) & - & - \\
\hline \multicolumn{3}{|l|}{ Outflow: } \\
\hline Runoff generated on piedmont slope (ROps) $)^{3}$ & - & $0-400$ \\
\hline Subsurface flow from basin-fill aquifer beneath piedmont slope to basin-fill aquifer beneath valley lowland (SFps) ${ }^{3}$ & - & $13,300-13,700$ \\
\hline Subsurface flow from basin-fill aquifer beneath piedmont slope to adjacent hydrographic areas (SFout) & - & - \\
\hline ET and sublimation of precipitation and soil moisture (ETps) $)^{3}$ & - & 46,400 \\
\hline \multirow{2}{*}{ ET from vegetated flood plains (ETrps) ${ }^{3}$} & - & $300-800$ \\
\hline & 60,000 & $60,000-61,000$ \\
\hline
\end{tabular}

Valley-lowland water budget

Inflow:

Precipitation on valley lowland (PVI) ${ }^{1}$

Runoff from piedmont slope to valley lowland (ROps) ${ }^{3}$

Surface-water flow from adjacent hydrographic areas (SWin)

Subsurface flow from basin-fill aquifer beneath piedmon
Subsurface flow from adjacent hydrographic areas (SFin)

Outflow:

Runoff generated on valley lowland (ROv)

Subsurface flow from basin-fill aquifer beneath valley lowland to Lower Reese River Hydrographic Area (SFv)

ET of precipitation and soil moisture (ETV)

ET of ground water from valley lowland (ETgw) ${ }^{7}$

Evaporation from open-water bodies (Esw) ${ }^{7}$

30,100

30,100
$0-400$

${ }^{4}, 000$

$13,300-13,700$

${ }^{5} 6,500$

$60,000-61,000$

Middle Reese River Valley Hydrographic Area water budget

\section{Inflow:}

Precipitation in Middle Reese River Valley Hydrographic Area (Pmb, Pps, Pvl)

Surface-water flow from adjacent hydrographic areas (SWin)

Subsurface flow from adjacent hydrographic areas (SFin)

Outflow:

Surface-water flow from Middle Reese River Valley Hydrographic Area at hydrographic-area boundary (SWtot)

Subsurface flow from Middle Reese River Valley Hydrographic Area at hydrographic-area boundary (SFtot)

ET and sublimation from Middle Reese River Valley Hydrographic Area (ETmb, ETps, ETrps, ETV, ETgw, Esw)

Total.

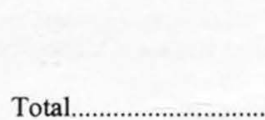

\begin{tabular}{|c|c|}
\hline 30,100 & - \\
\hline $0-400$ & - \\
\hline${ }^{4} 3,000$ & \\
\hline $13,300-13,700$ & 一 \\
\hline${ }^{5} 6,500$ & - \\
\hline - & 0 \\
\hline - & ${ }^{6} 9,000$ \\
\hline - & 30,100 \\
\hline - & $2,400-12,200$ \\
\hline - & 0 \\
\hline $53,000-54,000$ & $42,000-51,000$ \\
\hline
\end{tabular}

${ }^{1}$ See table 3.

${ }^{2}$ See table 4.

${ }^{3}$ See table 5 .

${ }^{4}$ Eakin and others (1965, p. 24).

${ }^{5}$ Combined values: 6,000 acre-feet per year estimated by Crosthwaite (1963, p. 15) to enter from Antelope Valley Hydrographic Area and additional 500 acre-feet per year estimated by Eakin and others $(1965$, p. 24) to enter from Upper Reese River Hydrographic Area. Estimate of 6,000 acre-feet per year not supported by recent work (Plume and Ponce, 1999).

${ }^{6}$ Crosthwaite (1963, p. 15).

${ }^{7}$ See table 6.

${ }^{8}$ Eakin and Lamke (1966, p. 59). 
Table 13. Average annual water budgets for Lower Reese River Valley Hydrographic Area, middle Humboldt River Basin, northcentral Nevada

[Bold symbols in parentheses correspond to those used in table 2 and fig. 3. Values for separate flow components rounded to nearest 100 acre-feet per year; totals rounded to nearest 1,000 acre-feet per year. ET, evapotranspiration. —, no data or not applicable]

\begin{tabular}{|c|c|c|}
\hline Water-budget components & $\begin{array}{c}\text { Inflow } \\
\text { (acre-feet } \\
\text { per year) }\end{array}$ & $\begin{array}{c}\text { Outflow } \\
\text { (acre-feet } \\
\text { per year) }\end{array}$ \\
\hline \multicolumn{3}{|l|}{ Mountain-block water budget } \\
\hline \multicolumn{3}{|l|}{ Inflow: } \\
\hline Precipitation on mountain block $(\mathrm{Pmb})^{1}$ & 146,900 & - \\
\hline $\begin{array}{l}\text { Subsurface flow from adjacent hydrographic areas to bedrock aquifer (SFin) } \\
\text { Outflow: }\end{array}$ & - & - \\
\hline Runoff from mountain block to piedmont slope (ROmb) ${ }^{2}$ & - & 4,800 \\
\hline Subsurface flow from bedrock aquifer in mountain block to basin-fill aquifer beneath piedmont slope (SFmb) ${ }^{2}$ & - & 13,700 \\
\hline Subsurface flow from mountain block to adjacent hydrographic areas (SFout) & - & - \\
\hline ET and sublimation of precipitation and soil moisture and ET from riparian areas (ETmb) ${ }^{2}$ & - & 128,400 \\
\hline 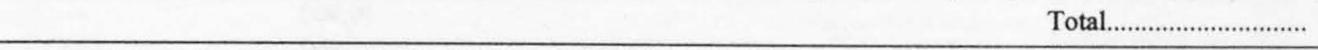 & 147,000 & 147,000 \\
\hline \multicolumn{3}{|l|}{ Piedmont-slope water budget } \\
\hline \multicolumn{3}{|l|}{ Inflow: } \\
\hline Precipitation on piedmont slope (Pps) ${ }^{1}$ & 104,100 & - \\
\hline Runoff from mountain block to piedmont slope (ROmb) ${ }^{2}$ & 4,800 & - \\
\hline Surface-water flow from adjacent hydrographic areas (SWIn) & 0 & - \\
\hline Subsurface flow from bedrock aquifer in mountain block to basin-fill aquifer beneath piedmont slope (SFmb) ${ }^{2}$ & 13,700 & - \\
\hline Subsurface flow from adjacent hydrographic areas (SFin) & - & - \\
\hline \multicolumn{3}{|l|}{ Outflow: } \\
\hline Runoff generated on piedmont slope (ROps) ${ }^{3}$ & - & $0-500$ \\
\hline Subsurface flow from basin-fill aquifer beneath piedmont slope to basin-fill aquifer beneath valley lowland (SFps) ${ }^{3}$ & - & $18,500-19,000$ \\
\hline Subsurface flow from basin-fill aquifer beneath piedmont slope to adjacent hydrographic areas (SFout) & - & - \\
\hline ET and sublimation of precipitation and soil moisture (ETps) ${ }^{3}$ & - & 104,100 \\
\hline \multirow[t]{2}{*}{ ET from vegetated flood plains (ETrps) $)^{3}$} & - & 100 \\
\hline & 123,000 & $123,000-124,000$ \\
\hline
\end{tabular}

Valley-lowland water budget

Inflow:

Precipitation on valley lowland $(\mathrm{Pv})^{1}$

Runoff from piedmont slope to valley lowland (ROps) ${ }^{3}$

Surface-water flow from adjacent hydrographic areas (SWin)

Subsurface flow from basin-fill aquifer beneath piedmont slope to basin-fill aquifer beneath valley lowland (SFps) ${ }^{3}$

Subsurface flow from adjacent hydrographic areas (SFIn)

Outflow:

Runoff generated on valley lowland (ROv)

Subsurface flow from basin-fill aquifer beneath valley lowland to adjacent hydrographic areas (SFv)

ET of precipitation and soil moisture (ETVI)

ET of ground water from valley lowland $(\mathrm{ETgw})^{5}$

Evaporation from open-water bodies (Esw) 5

Total...

Lower Reese River Valley Hydrographic Area water budget

\section{Inflow:}

Precipitation in Lower Reese River Valley Hydrographic Area (Pmb, Pps, Pvl)

Surface-water flow from adjacent hydrographic areas (SWin)

Subsurface flow from adjacent hydrographic areas (SFin)

Outflow:

Surface-water flow from Lower Reese River Valley Hydrographic Area at hydrographic-area boundary (SWtot)

Subsurface flow from Lower Reese River Valley Hydrographic Area at hydrographic-area boundary (SFtot)

ET and sublimation from Lower Reese River Valley Hydrographic Area (ETmb, ETps, ETrps, ETVI, ETgw, Esw)

Total........

$$
\begin{array}{r}
89,700 \\
0-500
\end{array}
$$

$-$

$18,500-19,000$

${ }^{4} 17,000$

$-\quad 0$

- $\quad 89,700$

- $\quad 30,700-79,800$

- $\quad 500-800$

$125,000-126,000 \quad 121,000-170,000$

1 See table 3

${ }^{2}$ See table 4.

${ }^{3}$ See table 5 ,

${ }^{4}$ Combined values: 9,000 acre-feet per year estimated by Crosthwaite (1963, p. 15) to enter from Middle Reese River Valley Hydrographic Area and 8,000 acre-feet per year esitmated by Rush and others (1971) to enter from Buffalo Valley Hydrographic Area. Estimate of 8,000 acre-feet per year not supported by recent work (Plume and Ponce, 1999).

${ }^{5}$ See table 6.

${ }^{6}$ Eakin and Lamke (1966, p. 36). 
Table 14. Average annual water budgets for Whirlwind Valley Hydrographic Area, middle Humboldt River Basin, north-central Nevada

[Bold symbols in parentheses correspond to those used in table 2 and fig. 3. Values for separate flow components rounded to nearest 100 acre-feet per year; totals rounded to nearest 1,000 acrefeet per year. ET, evapotranspiration. —, no data or not applicable]

\begin{tabular}{|c|c|c|}
\hline Water-budget components & $\begin{array}{c}\text { Inflow } \\
\text { (acre-feet } \\
\text { per year) }\end{array}$ & $\begin{array}{l}\text { Outflow } \\
\text { (acre-feet } \\
\text { per year) }\end{array}$ \\
\hline \multicolumn{3}{|l|}{ Mountain-block water budget } \\
\hline \multicolumn{3}{|l|}{ Inflow: } \\
\hline Precipitation on mountain block $(\mathrm{Pmb})^{1}$ & 34,100 & - \\
\hline Subsurface flow from adjacent hydrographic areas to bedrock aquifer (SFIn) & - & - \\
\hline \multicolumn{3}{|l|}{ Outflow: } \\
\hline Runoff from mountain block to piedmont slope (ROmb) ${ }^{2}$ & - & 900 \\
\hline Subsurface flow from bedrock aquifer in mountain block to basin-fill aquifer beneath piedmont slope (SFmb) ${ }^{2}$ & - & 2,800 \\
\hline Subsurface flow from mountain block to adjacent hydrographic areas (SFout) & - & - \\
\hline ET and sublimation of precipitation and soil moisture and ET from riparian areas (ETmb) ${ }^{2}$ & - & 30,400 \\
\hline 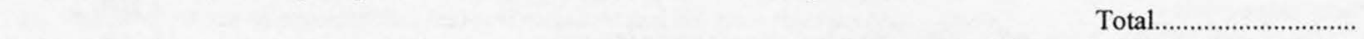 & 34,000 & 34,000 \\
\hline
\end{tabular}

Piedmont-slope water budget

Inflow:

Precipitation on piedmont slope (Pps) $)^{1}$

Runoff from mountain block to piedmont slope (ROmb) ${ }^{2}$

Surface-water flow from adjacent hydrographic areas (SWn)

Subsurface flow from bedrock aquifer in mountain block to basin-fill aquifer beneath piedmont slope (SFmb) ${ }^{2}$

Subsurface flow from adjacent hydrographic areas (SFIn)

Outflow:

Runoff generated on piedmont slope (ROps) ${ }^{3}$

Subsurface flow from basin-fill aquifer beneath piedmont slope to basin-fill aquifer beneath valley lowland (SFps) ${ }^{3}$

Subsurface flow from basin-fill aquifer beneath piedmont slope to adjacent hydrographic areas (SFout)

ET and sublimation of precipitation and soil moisture (ETPs) ${ }^{3}$

ET from vegetated flood plains (ETrps) ${ }^{3}$

Total.

\begin{tabular}{|c|c|}
\hline 10,900 & - \\
\hline 900 & - \\
\hline 0 & - \\
\hline 2,800 & - \\
\hline- & - \\
\hline- & $0-100$ \\
\hline - & $3,700-3,800$ \\
\hline - & - \\
\hline - & 10,900 \\
\hline- & 0 \\
\hline 15,000 & 15,000 \\
\hline
\end{tabular}

Valley-lowland water budget

Inflow:

Precipitation on valley lowland $(\mathrm{PV})^{1}$

Runoff from piedmont slope to valley lowland (ROps) ${ }^{3}$

Surface-water flow from adjacent hydrographic areas (sWin)

Subsurface flow from basin-fill aquifer beneath piedmont slope to basin-fill aquifer beneath valley lowland (SFps) ${ }^{3}$

Subsurface flow from adjacent hydrographic areas (SFIn)

Outflow:

Runoff generated on valley lowland (ROVI)

Subsurface flow from basin-fill aquifer beneath valley lowland to Crescent Valley Hydrographic Areas (SFv)

ET of precipitation and soil moisture (ETVI)

ET of ground water from valley lowland $(E T g w)^{5}$

Evaporation from open-water bodies (Esw) ${ }^{5}$

Total

\begin{tabular}{cc}
9,600 & - \\
$0-100$ & - \\
0 & - \\
$3,700-3,800$ & - \\
- & 0 \\
- & 4800 \\
- & 9,600 \\
- & $13,900-16,000$ \\
\hline- & $\frac{100}{24,000-26,000}$ \\
\hline $13,000-14,000$ &
\end{tabular}

Whirlwind Valley Hydrographic Area water budget

Inflow:

Precipitation in Whirlwind Valley Hydrographic Area (Pmb, Pps, Pvl)

Surface-water flow from adjacent hydrographic areas (SWn)

Subsurface flow from adjacent hydrographic areas (SFIn)

Outflow:

Surface-water flow from Whirlwind Valley Hydrographic Area at hydrographic-area boundary (sWtot)

Subsurface flow from Whirlwind Valley Hydrographic Area at hydrographic-area boundary (SFtot)

ET and sublimation from Whirlwind Valley Hydrographic Area (ETmb, ETps, ETrps, ETvl, ETgw, Esw)

Total

\begin{tabular}{|c|c|}
\hline 55,000 & - \\
\hline 0 & - \\
\hline- & - \\
\hline - & ${ }^{6} 0$ \\
\hline - & $\begin{array}{c}4^{4} 800 \\
64,900-67,000\end{array}$ \\
\hline 55,000 & $66,000-68,000$ \\
\hline
\end{tabular}

${ }^{1}$ See table 3 .

${ }^{2}$ See table 4 .

${ }^{3}$ See table 5 .

${ }^{4}$ Olmsted and Rush (1987, p. 38)

${ }^{5}$ See table 6.

${ }^{6}$ Olmsted and Rush (1987, p. 32). 
[Bold symbols in parentheses correspond to those used in table 2 and fig. 3. Values for separate flow components rounded to nearest 100 acre-feet per year; totals rounded to nearest 1,000 acre-feet per year. ET, evapotranspiration. —, no data or not applicable]

\begin{tabular}{|c|c|c|}
\hline Water-budget components & $\begin{array}{c}\text { Inflow } \\
\text { (acre-feet } \\
\text { per year) }\end{array}$ & $\begin{array}{l}\text { Outflow } \\
\text { (acre-feet } \\
\text { per year) }\end{array}$ \\
\hline \multicolumn{3}{|l|}{ Mountain-block water budget } \\
\hline \multicolumn{3}{|l|}{ Inflow: } \\
\hline Precipitation on mountain block $(\mathrm{Pmb})^{1}$ & 141,900 & - \\
\hline $\begin{array}{l}\text { Subsurface flow from adjacent hydrographic areas to bedrock aquifer (SFin) } \\
\text { Outflow. }\end{array}$ & - & - \\
\hline Runoff from mountain block to piedmont slope (ROmb) $)^{2}$ & \multicolumn{2}{|c|}{ Outflow: } \\
\hline Subsurface flow from bedrock aquifer in mountain block to basin-fill aquifer beneath piedmont slope (SFmb) ${ }^{2}$ & - & $\begin{array}{r}4,300 \\
12,800\end{array}$ \\
\hline Subsurface flow from mountain block to adjacent hydrographic areas (SFout) & - & - \\
\hline ET and sublimation of precipitation and soil moisture and ET from riparian areas (ETmb) ${ }^{2}$ & - & 124,800 \\
\hline Total................................ & 142,000 & 142,000 \\
\hline \multicolumn{3}{|l|}{ Piedmont-slope water budget } \\
\hline \multicolumn{3}{|l|}{ Inflow: } \\
\hline Precipitation on piedmont slope (Pps) ${ }^{1}$ & 66,000 & - \\
\hline Runoff from mountain block to piedmont slope (ROmb $)^{2}$ & 4,300 & - \\
\hline Surface-water flow from adjacent hydrographic areas (SWin) & - & - \\
\hline Subsurface flow from bedrock aquifer in mountain block to basin-fill aquifer beneath piedmont slope (SFmb) ${ }^{2}$ & 12,800 & - \\
\hline Subsurface flow from adjacent hydrographic areas (SFin) & - & - \\
\hline \multicolumn{3}{|l|}{ Outflow: } \\
\hline Runoff generated on piedmont slope (ROps) ${ }^{3}$ & - & $0-500$ \\
\hline Subsurface flow from basin-fill aquifer beneath piedmont slope to basin-fill aquifer beneath valley lowland (SFps) ${ }^{3}$ & - & $19,100-19,300$ \\
\hline Subsurface flow from basin-fill aquifer beneath piedmont slope to adjacent hydrographic areas (SFout) & - & - \\
\hline ET and sublimation of precipitation and soil moisture (ETPs) ${ }^{3}$ & - & 66,000 \\
\hline \multirow[t]{2}{*}{ ET from vegetated flood plains (ETrps) ${ }^{3}$} & - & $300-700$ \\
\hline & 83,000 & $85,000-86,000$ \\
\hline \multicolumn{3}{|l|}{ Valley-lowland water budget } \\
\hline \multicolumn{3}{|l|}{ Inflow: } \\
\hline Precipitation on valley lowland $(\mathrm{Pvl})^{1}$ & 99,700 & - \\
\hline Runoff from piedmont slope to valley lowland (ROps) ${ }^{3}$ & $0-500$ & - \\
\hline Surface-water flow from adjacent hydrographic areas (sWin) & ${ }^{4} 34,400$ & - \\
\hline Subsurface flow from basin-fill aquifer beneath piedmont slope to basin-fill aquifer beneath valley lowland (SFps) ${ }^{3}$ & $19,100-19,300$ & - \\
\hline Subsurface flow from adjacent hydrographic areas (SFIn) & - & - \\
\hline \multicolumn{3}{|l|}{ Outflow: } \\
\hline Runoff generated on valley lowland (ROv) & - & 0 \\
\hline Subsurface flow from basin-fill aquifer beneath valley lowland to adjacent hydrographic areas (SFvi) & - & 512,000 \\
\hline ET of precipitation and soil moisture (ETVI) & - & 99,700 \\
\hline ET of ground water from valley lowland (ETgw) ${ }^{6}$ & - & $92,100-147,400$ \\
\hline \multirow[t]{2}{*}{ Evaporation from open-water bodies $(\text { Esw })^{6}$} & - & $400-1,000$ \\
\hline & $153,000-154,000$ & $204,000-260,000$ \\
\hline
\end{tabular}

Boulder Flat Hydrographic Area water budget

Inflow:

Precipitation in Boulder Flat Hydrographic Area (Pmb, Pps, Pv)

Surface-water flow from adjacent hydrographic areas (SWin)

Subsurface flow from adjacent hydrographic areas (SFin)

Outflow:

Surface-water flow from Boulder Flat Hydrographic Area at hydrographic-area boundary (SWtot)

Subsurface flow from Boulder Flat Hydrographic Area at hydrographic-area boundary (SFtot)

ET and sublimation from Boulder Flat Hydrographic Area (ETmb, ETps, ETrps, ETVl, ETgw, Esw)

Total

\begin{tabular}{|c|c|c|}
\hline & $\begin{array}{c}308,000 \\
434,400\end{array}$ & $\frac{-}{-}$ \\
\hline & $\begin{array}{l}- \\
- \\
\end{array}$ & $\begin{array}{c}{ }^{7} 2,000 \\
{ }_{12}, 000 \\
383,300-439,600\end{array}$ \\
\hline$\ldots$ & 342,000 & $397,000-454,000$ \\
\hline
\end{tabular}

\footnotetext{
${ }^{1}$ See table 3.

${ }^{2}$ See table 4 .

${ }^{3}$ See table 5 .

${ }^{4}$ Average annual flow of Rock Creek (1961-90) entering Boulder Flat Hydrographic Area from Rock Creek Valley Hydrographic Area.

${ }^{5}$ Maurer and others (1996, p. 46).

${ }^{6}$ See table 6.

${ }^{7}$ Based on Maurer and others (1996, p. 27) and on estimated average annual flow of Humboldt River between Dunphy and Battle Mountain for the period of $1961-90$.
} 
Table 16. Average annual water budgets for Rock Creek Valley Hydrographic Area, middle Humboldt River Basin, north-central Nevada

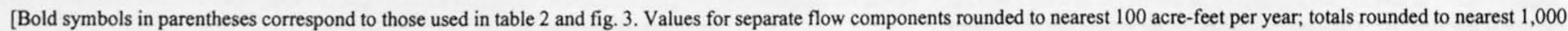
acre-feet per year. ET, evapotranspiration. - , no data or not applicable]

\begin{tabular}{|c|c|c|}
\hline Water-budget components & $\begin{array}{c}\text { Inflow } \\
\text { (acre-feet } \\
\text { per year) }\end{array}$ & $\begin{array}{l}\text { Outflow } \\
\text { (acre-feet } \\
\text { per year) }\end{array}$ \\
\hline \multicolumn{3}{|l|}{ Mountain-block water budget } \\
\hline \multicolumn{3}{|l|}{ Inflow: } \\
\hline Precipitation on mountain block $(\mathrm{Pmb})^{1}$ & 199,300 & - \\
\hline Subsurface flow from adjacent hydrographic areas to bedrock aquifer (SFin) & - & - \\
\hline \multicolumn{3}{|l|}{ Outflow: } \\
\hline Runoff from mountain block to piedmont slope $(\mathrm{ROmb})^{2}$ & - & 5,200 \\
\hline Subsurface flow from bedrock aquifer in mountain block to basin-fill aquifer beneath piedmont slope (SFmb $)^{2}$ & - & 17,100 \\
\hline Subsurface flow from mountain block to adjacent hydrographic areas (SFout) & - & - \\
\hline ET and sublimation of precipitation and soil moisture and ET from riparian areas (ETmb $)^{2}$ & - & 177,000 \\
\hline Total............................. & 199,000 & 199,000 \\
\hline \multicolumn{3}{|l|}{ Piedmont-slope water budget } \\
\hline \multicolumn{3}{|l|}{ Inflow: } \\
\hline Precipitation on piedmont slope (Pps) ${ }^{1}$ & 47,800 & - \\
\hline Runoff from mountain block to piedmont slope $(\mathrm{RO} \mathrm{mb})^{2}$ & 5,200 & - \\
\hline Surface-water flow from adjacent hydrographic areas (SWin) & - & - \\
\hline Subsurface flow from bedrock aquifer in mountain block to basin-fill aquifer beneath piedmont slope (SFmb) ${ }^{2}$ & 17,100 & - \\
\hline Subsurface flow from adjacent hydrographic areas (SFin) & - & - \\
\hline \multicolumn{3}{|l|}{$e^{2}$} \\
\hline Runoff generated on piedmont slope (ROps) ${ }^{3}$ & - & $0-600$ \\
\hline Subsurface flow from basin-fill aquifer beneath piedmont slope to basin-fill aquifer beneath valley lowland (SFps) ${ }^{3}$ & - & 17,100 \\
\hline Subsurface flow from basin-fill aquifer beneath piedmont slope to adjacent hydrographic areas (SFout) & - & - \\
\hline ET and sublimation of precipitation and soil moisture (ETps) ${ }^{3}$ & - & 47,800 \\
\hline \multirow[t]{2}{*}{ ET from vegetated flood plains $\left(\right.$ ETrps) ${ }^{3}$} & - & $600-800$ \\
\hline & 70,000 & 66,000 \\
\hline
\end{tabular}

\section{Valley-lowland water budget}

Inflow:

Precipitation on valley lowland (Pvi) ${ }^{1}$

Runoff from piedmont slope to valley lowland (ROps) ${ }^{3}$

Surface-water flow from adjacent hydrographic areas (SWin)

Subsurface flow from basin-fill aquifer beneath piedmont slope to basin-fill aquifer beneath valley lowland (SFps) ${ }^{3}$

Subsurface flow from adjacent hydrographic areas (SFIn)

Outflow:

Runoff generated on valley lowland (ROV)

Subsurface flow from basin-fill aquifer beneath valley lowland to adjacent hydrographic areas (SFvi)

ET of precipitation and soil moisture (ETVI)

ET of ground water from valley lowland (ETgw) ${ }^{4}$

Evaporation from open-water bodies (Esw) ${ }^{4}$

Total

8,700

$0-600$

-

17,100

-

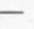

$-$

-

$-$

700

$$
\text { Evapation from opentwater bodies (Esw) }
$$

\section{Rock Creek Valley Hydrographic Area water budget}

Inflow:

Precipitation in Rock Creek Valley Hydrographic Area (Pmb, Pps, Pv)

Surface-water flow from adjacent hydrographic areas (SWin)

Subsurface flow from adjacent hydrographic areas (SFin)

Outflow:

Surface-water flow from Rock Creek Valley Hydrographic Area at hydrographic-area boundary (SWtot)

Subsurface flow from Rock Creek Valley Hydrographic Area at hydrographic-area boundary (SFtot)

ET and sublimation from Rock Creek Valley Hydrographic Area (ETmb, ETps, ETrps, ETvl, ETgw, Esw)

Total.......

\begin{tabular}{|c|c|c|}
\hline & & - \\
\hline & $\begin{array}{c}{ }^{5} 17,800 \\
-\end{array}$ & - \\
\hline $\begin{array}{l}\text { SWtot) } \\
\text { ot) }\end{array}$ & - & $\begin{array}{c}634,300 \\
72,800 \\
241,900-248,300 \\
\end{array}$ \\
\hline ……............. & 274,000 & $278,000-285,000$ \\
\hline
\end{tabular}

\footnotetext{
${ }^{1}$ See table 3.

${ }^{2}$ See table 4.

${ }^{3}$ See table 5 .

${ }^{4}$ See table 6.

${ }^{5}$ Estimated as 52 percent of estimated average annual flow (1961-90) of Rock Creek in Boulder Flat Hydrographic Area.

${ }^{6}$ Derived from contineous-stage-recording gage on Rock Creek (1961-90) in Boulder Flat Hydrographic Area.

${ }^{7}$ Maurer and others (1996, p. 46).
} 
Table 17. Average annual water budgets for Willow Creek Valley Hydrographic Area, middle Humboldt River Basin, north-central Nevada

[Bold symbols in parentheses correspond to those used in table 2 and fig. 3. Values for separate flow components rounded to nearest 100 acre-feet per year; totals rounded to nearest 1,000 acre-feet per year. ET, evapotranspiration. - , no data or not applicable]

\begin{tabular}{|c|c|c|}
\hline Water-budget components & $\begin{array}{c}\text { Inflow } \\
\text { (acre-feet } \\
\text { per year) }\end{array}$ & $\begin{array}{c}\text { Outflow } \\
\text { (acre-feet } \\
\text { per year) }\end{array}$ \\
\hline \multicolumn{3}{|l|}{ Mountain-block water budget } \\
\hline \multicolumn{3}{|l|}{ Inflow: } \\
\hline Precipitation on mountain block (Pmb) ${ }^{1}$ & 216,500 & - \\
\hline Subsurface flow from adjacent hydrographic areas to bedrock aquifer (SFin) & - & - \\
\hline \multicolumn{3}{|l|}{ Outflow: } \\
\hline Runoff from mountain block to piedmont slope $(\mathrm{RO} \mathrm{mb})^{2}$ & - & 10,300 \\
\hline Subsurface flow from bedrock aquifer in mountain block to basin-fill aquifer beneath piedmont slope (SFmb) ${ }^{2}$ & - & 22,900 \\
\hline Subsurface flow from mountain block to adjacent hydrographic areas (SFout) & - & - \\
\hline ET and sublimation of precipitation and soil moisture and ET from riparian areas (ETmb) ${ }^{2}$ & - & 183,300 \\
\hline 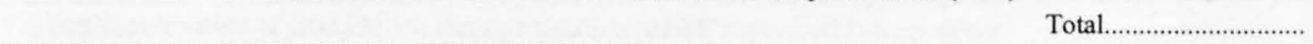 & 216,000 & 216,000 \\
\hline
\end{tabular}

\section{Piedmont-slope water budget}

Inflow:

Precipitation on piedmont slope $(\mathrm{Pps})^{1}$

Runoff from mountain block to piedmont slope (ROmb) ${ }^{2}$

Surface-water flow from adjacent hydrographic areas (SWin)

Subsurface flow from bedrock aquifer in mountain block to basin-fill aquifer beneath piedmont slope (SFmb) ${ }^{2}$

Subsurface flow from adjacent hydrographic areas (SFin)

Outflow:

Runoff generated on piedmont slope (ROps) ${ }^{3}$

Subsurface flow from basin-fill aquifer beneath piedmont slope to basin-fill aquifer beneath valley lowland (SFps) ${ }^{3}$

Subsurface flow from basin-fill aquifer beneath piedmont slope to adjacent hydrographic areas (SFout)

ET and sublimation of precipitation and soil moisture (ETps) ${ }^{3}$

ET from vegetated flood plains (ETrps) ${ }^{3}$

Total.

\begin{tabular}{|c|c|}
\hline 55,400 & - \\
\hline 10,300 & - \\
\hline- & - \\
\hline 22,900 & - \\
\hline - & - \\
\hline- & $0-1,100$ \\
\hline - & 27,500 \\
\hline - & - \\
\hline - & $50,100-55,400$ \\
\hline$=$ & $3,300-4,200$ \\
\hline 89,000 & $81,000-88,000$ \\
\hline
\end{tabular}

Valley-lowiand water budget

Inflow:

Precipitation on valley lowland $(\mathrm{Pv})^{1}$

Runoff from piedmont slope to valley lowland (ROps) ${ }^{3}$

Surface-water flow from adjacent hydrographic areas (sWin)

Subsurface flow from basin-fill aquifer beneath piedmont slope to basin-fill aquifer beneath valley lowland (SFps) ${ }^{3}$

Subsurface flow from adjacent hydrographic areas (SFin)

Outflow:

Runoff generated on valley lowland (ROvi)

Subsurface flow from basin-fill aquifer beneath valley lowland to adjacent hydrographic areas (SFvl)

ET of precipitation and soil moisture (ETVI)

ET of ground water from valley lowland $(\mathrm{ETgw})^{4}$

Evaporation from open-water bodies (Esw) ${ }^{4}$

\begin{tabular}{|c|c|c|}
\hline & $\begin{array}{l}- \\
-\end{array}$ & $\begin{array}{c}9,100 \\
19,200-21,800 \\
0\end{array}$ \\
\hline otal. & $37,000-38,000$ & $28,000-31,000$ \\
\hline
\end{tabular}

Willow Creek Valley Hydrographic Area water budget

Inflow:

Precipitation in Willow Creek Valley Hydrographic Area (Pmb, Pps, Pv)

Surface-water flow from adjacent hydrographic areas (SWin)

Subsurface flow from adjacent hydrographic areas (SFin)

Outflow:

Surface-water flow from Willow Creek Valley Hydrographic Area at hydrographic-area boundary (SWtot)

Subsurface flow from Willow Creek Valley Hydrographic Area at hydrographic-area boundary (SFtot)

ET and sublimation from Willow Creek Valley Hydrographic Area (ETmb, ETps, ETrps, ETvl, ETgw, Esw)

Total.

9,100

$0-1,100$

27,500

$-$

E

Total......................... 280,000

\footnotetext{
${ }^{1}$ See table 3.

${ }^{2}$ See table 4

${ }^{3}$ See table 5 .

${ }^{4}$ See table 6

${ }^{5}$ Estimated as 52 percent of average annual flow (1961-90) of Rock Creek in Boulder Flat Hydrographic Area.

${ }^{6}$ Maurer and others (1996, p. 46).
} 
Table 18. Average annual water budgets for Clovers Area, middle Humboldt River Basin, north-central Nevada

[Bold symbols in parentheses correspond to those used in table 2 and fig. 3. Values for separate flow components rounded to nearest 100 acre-feet per year; totals rounded to nearest 1,000 acre-feet per year. ET, evapotranspiration. -, no data or not applicable]

\begin{tabular}{l}
\hline \multicolumn{1}{c}{ Water-budget components } \\
\hline \multicolumn{1}{c}{ Mountain-block water budget } \\
\hline Inflow:
\end{tabular}

Piedmont-slope water budget

Inflow:

Precipitation on piedmont slope (Pps) ${ }^{1}$

Runoff from mountain block to piedmont slope $(\mathrm{ROMb})^{2}$

Surface-water flow from adjacent hydrographic areas (SWin)

Subsurface flow from bedrock aquifer in mountain block to basin-fill aquifer beneath piedmont slope (SFmb) ${ }^{2}$

Subsurface flow from adjacent hydrographic areas (SFin)

Outflow:

Runoff generated on piedmont slope (ROps) ${ }^{3}$

Subsurface flow from basin-fill aquifer beneath piedmont slope to basin-fill aquifer beneath valley lowland (SFps) ${ }^{3}$

Subsurface flow from basin-fill aquifer beneath piedmont slope to adjacent hydrographic areas (SFout)

ET and sublimation of precipitation and soil moisture (ETPs) ${ }^{3}$

ET from vegetated flood plains (ETrps) ${ }^{3}$

Total.

Valley-lowland water budget

Inflow:

Precipitation on valley lowland (PV) ${ }^{1}$

Runoff from piedmont slope to valley lowland (ROps) ${ }^{3}$

Surface-water flow from adjacent hydrographic areas (SWin)

Subsurface flow from basin-fill aquifer beneath piedmont slope to basin-fill aquifer beneath valley lowland (SFps) ${ }^{3} \quad 17,900-18,400$

Subsurface flow from adjacent hydrographic areas (SFin)

Outflow:

Runoff generated on valley lowland (ROVI)

Subsurface flow from basin-fill aquifer beneath valley lowland to adjacent hydrographic areas (SFv)

ET of precipitation and soil moisture (ETVI)

ET of ground water from valley lowland (ETgw) ${ }^{4}$

Evaporation from open-water bodies (Esw) ${ }^{4}$

\begin{tabular}{|c|c|c|}
\hline areas (SFv) & $\begin{array}{l}- \\
- \\
-\end{array}$ & $\begin{array}{c}- \\
103,600 \\
53,900-108,200 \\
500-3,600\end{array}$ \\
\hline Total.............................. & 122,000 & $158,000-216,000$ \\
\hline
\end{tabular}

Clovers Area water budget

Inflow:

Precipitation in Clovers Area (Pmb, Pps, Pvl)

Surface-water flow from adjacent hydrographic areas (SWin)

Subsurface flow from adjacent hydrographic areas (SFin)

Outflow:

Surface-water flow from Clovers Area at hydrographic-area boundary (SWrot)

Subsurface flow from Clovers Area at hydrographic-area boundary (SFtot)

ET and sublimation from Clovers Area (ETmb, ETps, ETrps, ETV, ETgw, Esw)

\begin{tabular}{ccc}
401,000 & - \\
${ }^{5} 19,100$ & - \\
& - & - \\
Total....................... & - & \\
& & $441,700-\overline{5} 02,300$ \\
\hline $442,000-502,000$ \\
\hline
\end{tabular}

\footnotetext{
1 See table 3.

${ }^{2}$ See table 4 .

${ }^{3}$ See table 5 .

${ }^{4}$ See table 6 .

${ }^{5}$ Maurer and others (1996, p. 46).
} 
Table 19. Average annual water budgets for Pumpernickel Valley Hydrographic Area, middle Humboldt River Basin, north-central Nevada

[Bold symbols in parentheses correspond to those used in table 2 and fig. 3. Values for separate flow components rounded to nearest 100 acre-feet per year; totals rounded to nearest 1,000 acre-feet per year. ET, evapotranspiration. —, no data or not applicable]

\begin{tabular}{|c|c|c|}
\hline Water-budget components & $\begin{array}{c}\text { Inflow } \\
\text { (acre-feet } \\
\text { per year) }\end{array}$ & $\begin{array}{l}\text { Outflow } \\
\text { (acre-feet } \\
\text { per year) }\end{array}$ \\
\hline \multicolumn{3}{|l|}{ Mountain-block water budget } \\
\hline \multicolumn{3}{|l|}{ Inflow: } \\
\hline Precipitation on mountain block (Pmb) ${ }^{1}$ & 74,100 & - \\
\hline Subsurface flow from adjacent hydrographic areas to bedrock aquifer (SFin) & - & - \\
\hline \multicolumn{3}{|l|}{ Outflow: } \\
\hline Runoff from mountain block to piedmont slope $(\mathrm{RO} \mathrm{mb})^{2}$ & - & 2,200 \\
\hline Subsurface flow from bedrock aquifer in mountain block to basin-fill aquifer beneath piedmont slope (SFmb) ${ }^{2}$ & - & 6,600 \\
\hline Subsurface flow from mountain block to adjacent hydrographic areas (SFout) & - & - \\
\hline ET and sublimation of precipitation and soil moisture and ET from riparian areas (ETmb) ${ }^{2}$ & - & 65,300 \\
\hline Total............................... & 74,000 & 74,000 \\
\hline \multicolumn{3}{|l|}{ Piedmont-slope water budget } \\
\hline \multicolumn{3}{|l|}{ Inflow: } \\
\hline Precipitation on piedmont slope (Pps) ${ }^{1}$ & 58,300 & - \\
\hline Runoff from mountain block to piedmont slope (ROmb) ${ }^{2}$ & 2,200 & - \\
\hline Surface-water flow from adjacent hydrographic areas (SWin) & - & - \\
\hline Subsurface flow from bedrock aquifer in mountain block to basin-fill aquifer beneath piedmont slope (SFmb) ${ }^{2}$ & 6,600 & - \\
\hline \multirow{2}{*}{\multicolumn{3}{|c|}{ Outflow: }} \\
\hline & & \\
\hline Runoff generated on piedmont slope (ROps) ${ }^{3}$ & - & $0-200$ \\
\hline Subsurface flow from basin-fill aquifer beneath piedmont slope to basin-fill aquifer beneath valley lowland (SFps) ${ }^{3}$ & - & $8,800-9,000$ \\
\hline Subsurface flow from basin-fill aquifer beneath piedmont slope to adjacent hydrographic areas (SFout) & - & - \\
\hline ET and sublimation of precipitation and soil moisture (ETps) $)^{3}$ & - & 58,300 \\
\hline \multirow[t]{2}{*}{ ET from vegetated flood plains (ETrps) ${ }^{3}$} & - & $500-700$ \\
\hline & 67,000 & 68,000, \\
\hline \multicolumn{3}{|l|}{ Valley-lowland water budget } \\
\hline \multicolumn{3}{|l|}{ Inflow: } \\
\hline Precipitation on valley lowland $(\mathrm{Pv})^{1}$ & 36,600 & - \\
\hline Runoff from piedmont slope to valley lowland (ROps) ${ }^{3}$ & $0-200$ & - \\
\hline Surface-water flow from adjacent hydrographic areas (SWin) & - & - \\
\hline Subsurface flow from basin-fill aquifer beneath piedmont slope to basin-fill aquifer beneath valley lowland (SFps) ${ }^{3}$ & $8,800-9,000$ & - \\
\hline Subsurface flow from adjacent hydrographic areas (SFin) & - & - \\
\hline \multicolumn{3}{|l|}{ Outflow: } \\
\hline Runoff generated on valley lowland (ROvl) & - & 0 \\
\hline Subsurface flow from basin-fill aquifer beneath valley lowland to adjacent hydrographic areas (SFv) & - & - \\
\hline ET of precipitation and soil moisture (ETV) & - & 36,600 \\
\hline ET of ground water from valley lowland $(E T g w)^{4}$ & - & $21,100-37,200$ \\
\hline \multirow[t]{2}{*}{ Evaporation from open-water bodies (Esw) ${ }^{4}$} & - & $400-1,000$ \\
\hline & $45,000-46,000$ & $58,000-75,000$ \\
\hline \multicolumn{3}{|l|}{ Pumpernickel Valley Hydrographic Area water budget } \\
\hline \multicolumn{3}{|l|}{ Inflow: } \\
\hline Precipitation in Pumpernickel Valley Hydrographic Area (Pmb, Pps, Pvl) & 169,000 & - \\
\hline Surface-water flow from adjacent hydrographic areas (SWin) & - & - \\
\hline \multirow{2}{*}{\multicolumn{3}{|c|}{$\begin{array}{l}\text { Subsurface flow trom adjacent nydrograpnic areas (Stin) } \\
\text { Outflow: }\end{array}$}} \\
\hline & & \\
\hline Surface-water flow from Pumpernickel Valley Hydrographic Area at hydrographic-area boundary (SWtot) & - & - \\
\hline Subsurface flow from Pumpernickel Valley Hydrographic Area at hydrographic-area boundary (SFtot) & - & - \\
\hline ET and sublimation from Pumpernickel Valley Hydrographic Area (ETmb, ETps, ETrps, ETVI, ETgw, Esw) & - & $182,200-199,100$ \\
\hline Total............... & 169,000 & $182,000-199,000$ \\
\hline
\end{tabular}

\footnotetext{
${ }^{1}$ See table 3 .

${ }^{2}$ See table 4 .

${ }^{3}$ See table 5 .

${ }^{4}$ See table 6 .
} 


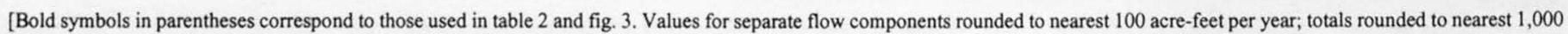
acre-feet per year. ET, evapotranspiration. -, no data or not applicable]

\begin{tabular}{|c|c|c|}
\hline Water-budget components & $\begin{array}{c}\text { Inflow } \\
\text { (acre-feet } \\
\text { per year) }\end{array}$ & $\begin{array}{l}\text { Outflow } \\
\text { (acre-feet } \\
\text { per year) }\end{array}$ \\
\hline \multicolumn{3}{|l|}{ Mountain-block water budget } \\
\hline \multicolumn{3}{|l|}{ Inflow: } \\
\hline Precipitation on mountain block $(\mathrm{Pmb})^{1}$ & 72,800 & - \\
\hline Subsurface flow from adjacent hydrographic areas to bedrock aquifer (SFin) & - & - \\
\hline \multicolumn{3}{|l|}{ Outflow: } \\
\hline Runoff from mountain block to piedmont slope (ROmb) ${ }^{2}$ & - & 4,400 \\
\hline Subsurface flow from bedrock aquifer in mountain block to basin-fill aquifer beneath piedmont slope (SFmb) ${ }^{2}$ & - & 8,300 \\
\hline Subsurface flow from mountain block to adjacent hydrographic areas (SFout) & - & - \\
\hline ET and sublimation of precipitation and soil moisture and ET from riparian areas (ETmb) ${ }^{2}$ & - & 60,100 \\
\hline Total.............................. & 73,000 & 73,000 \\
\hline \multicolumn{3}{|l|}{ Piedmont-slope water budget } \\
\hline \multicolumn{3}{|l|}{ Inflow: } \\
\hline Precipitation on piedmont slope (Pps) ${ }^{1}$ & 69,700 & - \\
\hline Runoff from mountain block to piedmont slope (ROmb) ${ }^{2}$ & 4,400 & - \\
\hline Surface-water flow from adjacent hydrographic areas (SWin) & - & - \\
\hline Subsurface flow from bedrock aquifer in mountain block to basin-fill aquifer beneath piedmont slope (SFmb) ${ }^{2}$ & 8,300 & - \\
\hline Subsurface flow from adjacent hydrographic areas (SFin) & - & - \\
\hline \multicolumn{3}{|l|}{ Outflow: } \\
\hline Runoff generated on piedmont slope (ROps) ${ }^{3}$ & - & $0-500$ \\
\hline Subsurface flow from basin-fill aquifer beneath piedmont slope to basin-fill aquifer beneath valley lowland (SFps) ${ }^{3}$ & - & $12,700-13,200$ \\
\hline Subsurface flow from basin-fill aquifer beneath piedmont slope to adjacent hydrographic areas (SFout) & - & - \\
\hline ET and sublimation of precipitation and soil moisture $(\mathrm{ETPs})^{3}$ & - & 69,700 \\
\hline \multirow{2}{*}{ ET from vegetated flood plains (ETrps) ${ }^{3}$} & - & $1,600-2,300$ \\
\hline & 82,000 & $84,000-86,000$ \\
\hline
\end{tabular}

\section{Valley-lowland water budget}

Inflow:

Precipitation on valley lowland (Pv) $)^{1}$

Runoff from piedmont slope to valley lowland (ROps) ${ }^{3}$

Surface-water flow from adjacent hydrographic areas (SWin)

Subsurface flow from basin-fill aquifer beneath piedmont slope to basin-fill aquifer beneath valley lowland (SFps) ${ }^{3} \quad 12,700-13,200$

Subsurface flow from adjacent hydrographic areas (SFin)

Outflow:

Runoff generated on valley lowland (ROvi)

Subsurface flow from basin-fill aquifer beneath valley lowland to adjacent hydrographic areas (SFv)

ET of precipitation and soil moisture (ETV)

ET of ground water from valley lowland (ETgw) ${ }^{4}$

Evaporation from open-water bodies (Esw) ${ }^{4}$

\begin{tabular}{|c|c|c|}
\hline & 37,600 & - \\
\hline \multirow{3}{*}{ th valley lowland (SFps) ${ }^{3}$} & $\begin{array}{c}0-500 \\
-\end{array}$ & - \\
\hline & $12,700-13,200$ & - \\
\hline & - & - \\
\hline \multirow{5}{*}{ areas (SFv) } & - & 0 \\
\hline & - & - \\
\hline & - & 37,600 \\
\hline & - & $14,500-35,900$ \\
\hline & - & $0-400$ \\
\hline 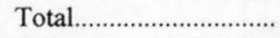 & $50,000-51,000$ & $52,000-74,000$ \\
\hline
\end{tabular}

Kelly Creek Area water budget

Inflow:

Precipitation in Kelly Creek Area (Pmb, Pps, Pv1)

Surface-water flow from adjacent hydrographic areas (SWin)

Subsurface flow from adjacent hydrographic areas (SFin)

Outflow:

Surface-water flow from Kelly Creek Area at hydrographic-area boundary (SWtot)

Subsurface flow from Kelly Creek Area at hydrographic-area boundary (SFtot)

ET and sublimation from Kelly Creek Area (ETmb, ETps, ETrps, ETvl, ETgw, Esw)

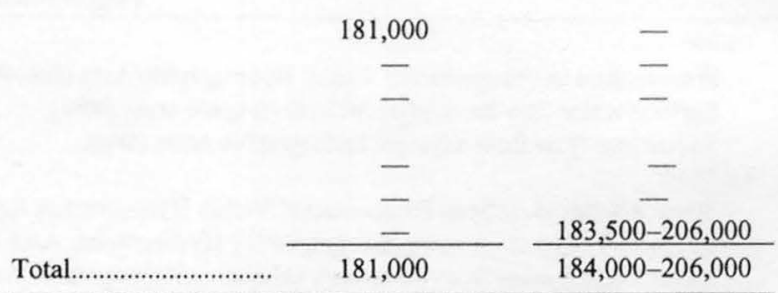

\footnotetext{
${ }^{1}$ See table 3 .

${ }^{2}$ See table 4 .

${ }^{3}$ See table 5 .

${ }^{4}$ See table 6 .
} 
Table 21. Estimated average annual ground-water budget for the 14 hydrographic areas, middle Humboldt River Basin, north-central Nevada

[Values for separate flow components and subtotals rounded to nearest 100 acre-feet per year; totals rounded to nearest 1,000 acre-feet per year. Bold symbols (in footnotes) correspond to those used in table 2 and fig. 3 . -, no data or not applicable; < less than]

\begin{tabular}{|c|c|c|c|c|c|c|c|}
\hline \multirow{2}{*}{ Ground-water-budget component } & \multicolumn{7}{|c|}{$\begin{array}{l}\text { Estimated flow } \\
\text { (acre-feet per year) }\end{array}$} \\
\hline & Pine Valley & Crescent Valley & $\begin{array}{l}\text { Carico Lake } \\
\text { Valley }\end{array}$ & $\begin{array}{l}\text { Upper Reese } \\
\text { River Valley }\end{array}$ & Antelope Valley & $\begin{array}{l}\text { Middle Reese } \\
\text { River Valley }\end{array}$ & $\begin{array}{l}\text { Lower Reese } \\
\text { River Valley }\end{array}$ \\
\hline \multicolumn{8}{|c|}{ Inflow } \\
\hline \multicolumn{8}{|l|}{ Ground-water recharge: } \\
\hline To mountain block ${ }^{1}$ & 38,200 & 18,200 & 13,000 & 47,700 & 12,200 & 10,200 & 13,700 \\
\hline To piedmont slope, from runoff ${ }^{2}$ & $14,200-16,700$ & $7,000-7,800$ & $5,700-6,300$ & $23,600-26,600$ & $5,000-6,000$ & $2,600-3,000$ & $4,800-5,300$ \\
\hline To piedmont slope, from precipitation ${ }^{3}$ & $0-24,300$ & $0-200$ & $0-1,100$ & $0-35,600$ & $0-7,000$ & 0 & 0 \\
\hline 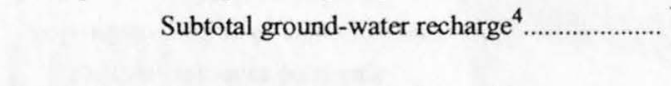 & $\begin{array}{c}\overline{52,500-79,300} \\
(66,000)\end{array}$ & $\begin{array}{c}25,200-26,200 \\
(21,000)\end{array}$ & $\begin{array}{c}18,700-20,400 \\
(18,000)\end{array}$ & $\begin{array}{c}71,400-110,000 \\
(93,000)\end{array}$ & $\begin{array}{c}17,200-25,200 \\
(19,000)\end{array}$ & $\begin{array}{c}12,800-13,200 \\
(10,000)\end{array}$ & $\begin{array}{c}18,500-19,000 \\
(13,000)\end{array}$ \\
\hline Subsurface inflow from adjacent hydrographic areas & 0 & ${ }^{5} 700$ & $6_{3,000}$ & 0 & 0 & ${ }^{7} 6,500$ & ${ }^{8} 17,000$ \\
\hline 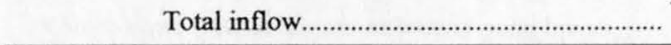 & $\overline{52,000-79,000}$ & $26,000-27,000$ & $22,000-23,000$ & $71,000-110,000$ & $17,000-25,000$ & $19,000-20,000$ & 36,000 \\
\hline \multicolumn{8}{|c|}{ Outflow } \\
\hline Ground-water evapotranspiration in valley lowlands 9 & $39,500-50,300$ & $19,600-37,100$ & $4,800-9,600$ & $43,800-45,800$ & $2,000-8,400$ & $2,400-12,200$ & $30,700-79,800$ \\
\hline Ground-water discharge from vegetated flood plains ${ }^{10}$ & $3,200-4,100$ & $500-1,900$ & $1,100-1,200$ & $10,900-11,700$ & $200-600$ & $300-800$ & 100 \\
\hline $\begin{array}{l}\text { Ground-water discharge as surface-water outflow at } \\
\text { hydrographic-area boundary. }\end{array}$ & ${ }^{11} 5,000$ & ${ }^{12} 0$ & - & ${ }^{11}<1,000$ & - & - & - \\
\hline Subsurface outflow to adjacent hydrographic areas & ${ }^{13} 9,300$ & ${ }^{14}<300$ & ${ }^{15}<300$ & ${ }^{16} 3,500$ & ${ }^{17} 6,000$ & ${ }^{17} 9,000$ & - \\
\hline 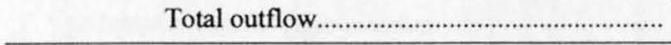 & $57,000-69,000$ & $20,000-39,000$ & $6,000-11,000$ & $59,000-62,000$ & $8,000-15,000$ & $12,000-22,000$ & $31,000-80,000$ \\
\hline
\end{tabular}

\section{Continued}




\begin{tabular}{|c|c|c|c|c|c|c|c|}
\hline \multirow{2}{*}{ Ground-water-budget component } & \multicolumn{7}{|c|}{$\begin{array}{c}\text { Estimated flow } \\
\text { (acre-feet per year) }\end{array}$} \\
\hline & $\begin{array}{l}\text { Whirlwind } \\
\text { Valley }\end{array}$ & Boulder Flat & $\begin{array}{l}\text { Rock Creek } \\
\text { Valley }\end{array}$ & $\begin{array}{l}\text { Willow Creek } \\
\text { Valley }\end{array}$ & Clovers Area & $\begin{array}{l}\text { Pumpernickel } \\
\text { Valley }\end{array}$ & $\begin{array}{l}\text { Kelly Creek } \\
\text { Area }\end{array}$ \\
\hline \multicolumn{8}{|c|}{ Inflow } \\
\hline \multicolumn{8}{|l|}{ Ground-water recharge: } \\
\hline To mountain block ${ }^{1}$ & 2,800 & 12,800 & 17,100 & 22,900 & 13,100 & 6,600 & 8,300 \\
\hline To piedmont slope, from runoff ${ }^{2}$ & $900-1,000$ & $6,300-6,500$ & 0 & 0 & $4,800-5,300$ & $2,200-2,400$ & $4,400-4,900$ \\
\hline To piedmont slope, from precipitation ${ }^{3}$ & 0 & 0 & 0 & 4,600 & 0 & 0 & 0 \\
\hline 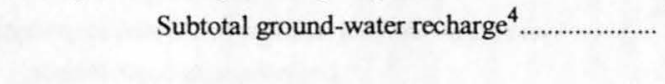 & $\begin{array}{c}3,700-3,800 \\
(2,000)\end{array}$ & $\begin{array}{c}19,100-19,300 \\
(11,000)\end{array}$ & $\begin{array}{l}17,100 \\
(9,000)\end{array}$ & $\begin{array}{c}27,500 \\
(28,000)\end{array}$ & $\begin{array}{c}17,900-18,400 \\
(13,000)\end{array}$ & $\begin{array}{c}8,800-9,000 \\
(7,500)\end{array}$ & $\begin{array}{c}12,700-13,200 \\
(11,000)\end{array}$ \\
\hline Subsurface inflow from adjacent hydrographic areas & 一 & - & - & - & - & - & - \\
\hline 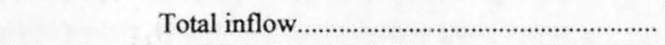 & 4,000 & 19,000 & 17,000 & 28,000 & 18,000 & 9,000 & 13,000 \\
\hline \multicolumn{8}{|c|}{ Outflow } \\
\hline Ground-water evapotranspiration in valley lowlands ${ }^{9}$ & $13,900-16,000$ & $92,100-147,400$ & $7,800-14,000$ & $19,200-21,800$ & $53,900-108,300$ & $21,200-37,200$ & $14,600-35,900$ \\
\hline Ground-water discharge from vegetated flood plains ${ }^{10}$ & 0 & $300-700$ & $600-800$ & $3,300-4,200$ & $4,400-7,600$ & $500-700$ & $1,600-2,300$ \\
\hline $\begin{array}{l}\text { Ground-water discharge as surface-water outflow at } \\
\text { hydrographic-area boundary. }\end{array}$ & - & - & - & - & - & - & - \\
\hline Subsurface outflow to adjacent hydrographic areas & ${ }^{18} 800$ & ${ }^{19} 12,000$ & ${ }^{19} 2,800$ & ${ }^{19} 4,300$ & - & - & - \\
\hline Total outflow & $15,000-17,000$ & $104,000-160,000$ & $11,000-18,000$ & $27,000-30,000$ & $58,000-116,000$ & $22,000-38,000$ & $16,000-38,000$ \\
\hline
\end{tabular}

${ }^{1}$ See table 4

${ }^{2}$ Estimated as difference between sum of mountain-block runoff (ROmb; table 4) plus piedmont-slope runoff (ROps; table 5) and total runoff at hydrographic-area boundary (SWtot; tables 7-20)

${ }^{3}$ Estimated as difference between piedmont-slope precipitation (Pps; table 3) and sum of piedmont-slope runoff (ROps; table 5) plus evapotranspiration components (ETps and ETRps; table 5).

${ }^{4}$ Estimated from mass-balance calculation. Values in parentheses estimated from revised recharge Maxey-Eakin method (equation 3 in text; values shown for comparison only, not used in ground-water budget calculations).

${ }^{5}$ Combined values; 300 acre-feet per year estimated by Everett and Rush (1966, p. 17) to enter from Carico Lake Valley Hydrographic Area and additional 400 acre-feet per year estimated by Olmsted and Rush (1987, p. 32) to enter from Whirlwind Valley Hydrographic Area.

${ }^{6}$ Estimated from equation 4 (see text).

${ }^{7}$ Combined values: 6,000 acre-feet per year estimated by Crosthwaite (1963, p. 15) to enter from Antelope Valley Hydrographic Area and additional 500 acre-feet per year estimated by Eakin and others (1965, p. 24) to enter from Upper Reese River Valley Hydrographic Area.

${ }^{8}$ Combined values: 9,000 acre-feet per year estimated by Crosthwaite (1963, p. 15) to enter from Middle Reese River Valley Hydrographic Area and 8,000 acre-feet per year estimated by Rush and others (1971) to enter from Buffalo Valley Hydrographic Area.

${ }^{9}$ See table 6 .

${ }^{10}$ See table 5 .

${ }^{11}$ Estimated by hydrograph-separation analysis (Rorabaugh, 1964) and from Eakin (1961, p. 10)

${ }^{12}$ Zones (1961, p.11) and Olmsted and Rush (1987, p. 32).

${ }^{13}$ Combined values: 9,000 acre-feet per year estimated by Harrill $(1968$, p. 28$)$ to exit from Garden Valley, subbasin in southeastern part of Pine Valley Hydrographic Area, and additional 300 acre-feet per year estimated by Eakin $(1961$, p. 26$)$ to exit Pine Valley beneath north hydrographic-area boundary.

${ }^{14}$ Zones (1961, p. 23).

${ }^{15}$ Everett and Rush (1966, p. 17)

${ }^{16}$ Combined values: 3,000 acre-feet per year to Carico Lake Valley Hydrographic Area estimated from equation 4 (see text) and less than 500 acre-feet per year to Middle Reese River Valley Hydrographic Area, estimated by Eakin and others (1965).

${ }^{17}$ Crosthwaite (1968, p. 15)

${ }^{18}$ Olmsted and Rush (1987, p. 38).

${ }^{19}$ Maurer and others (1996, p. 46). 


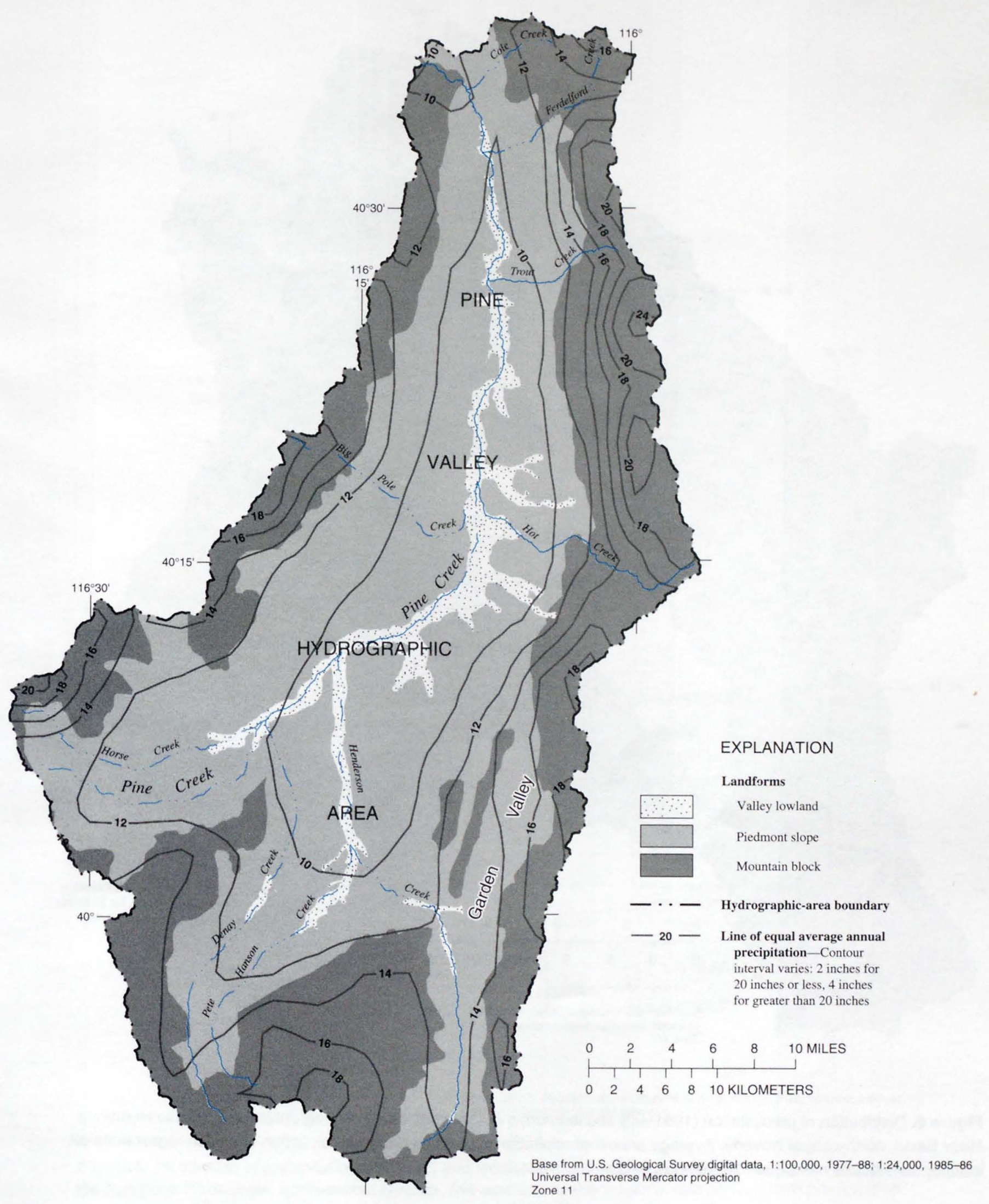

Figure 4. Distribution of precipitation (1961-90) and landforms in Pine Valley Hydrographic Area, middle Humboldt River Basin, north-central Nevada. Average annual-precipitation data derived from precipitation-elevation regressions on independent slopes model, or PRISM (Daly and others, 1994). 


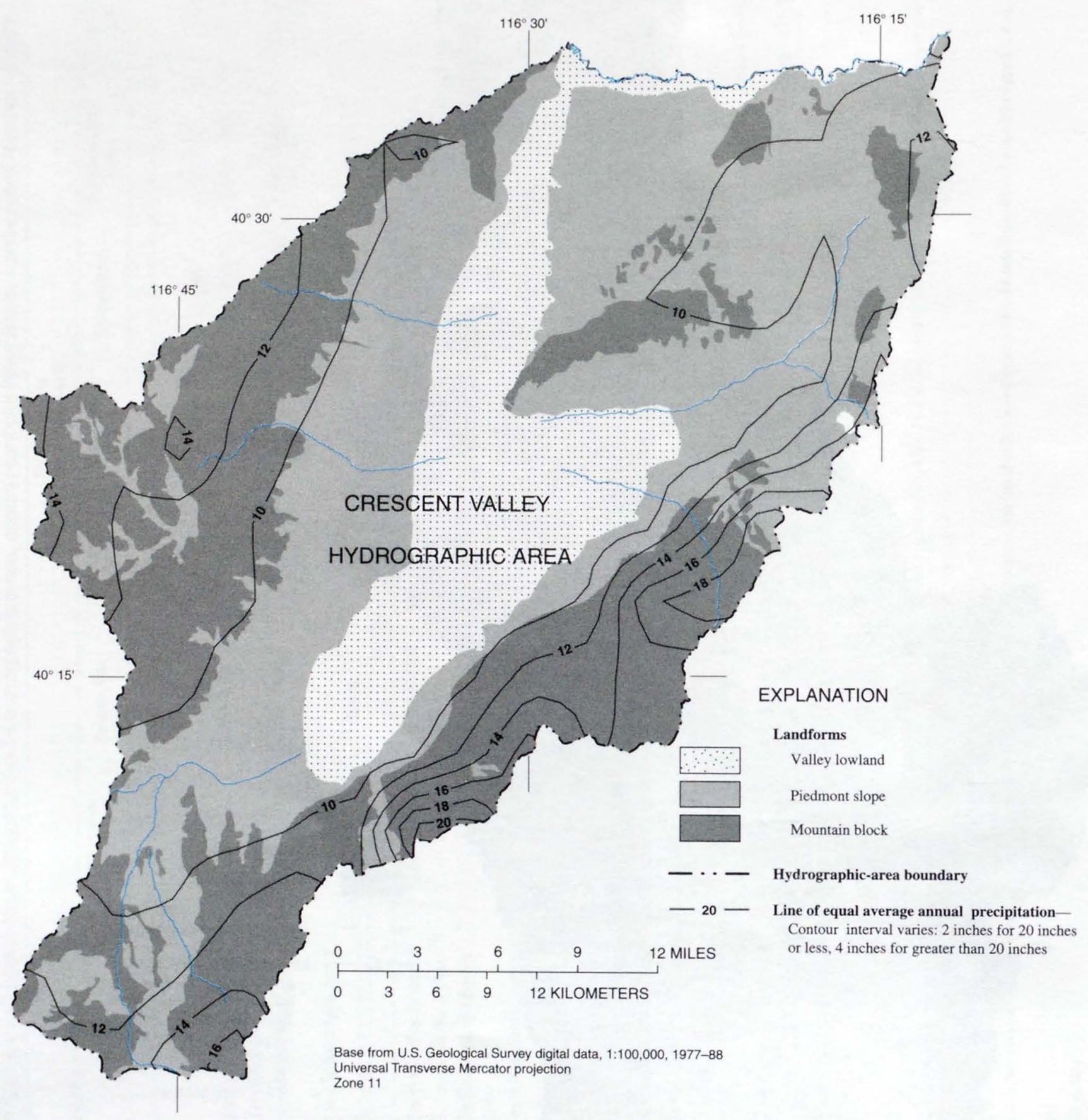

Figure 5. Distribution of precipitation (1961-90) and landforms in Crescent Valley Hydrographic Area, middle Humboldt River Basin, north-central Nevada. Average annual-precipitation data derived from precipitation-elevation regressions on independent slopes model, or PRISM (Daly and others, 1994). 


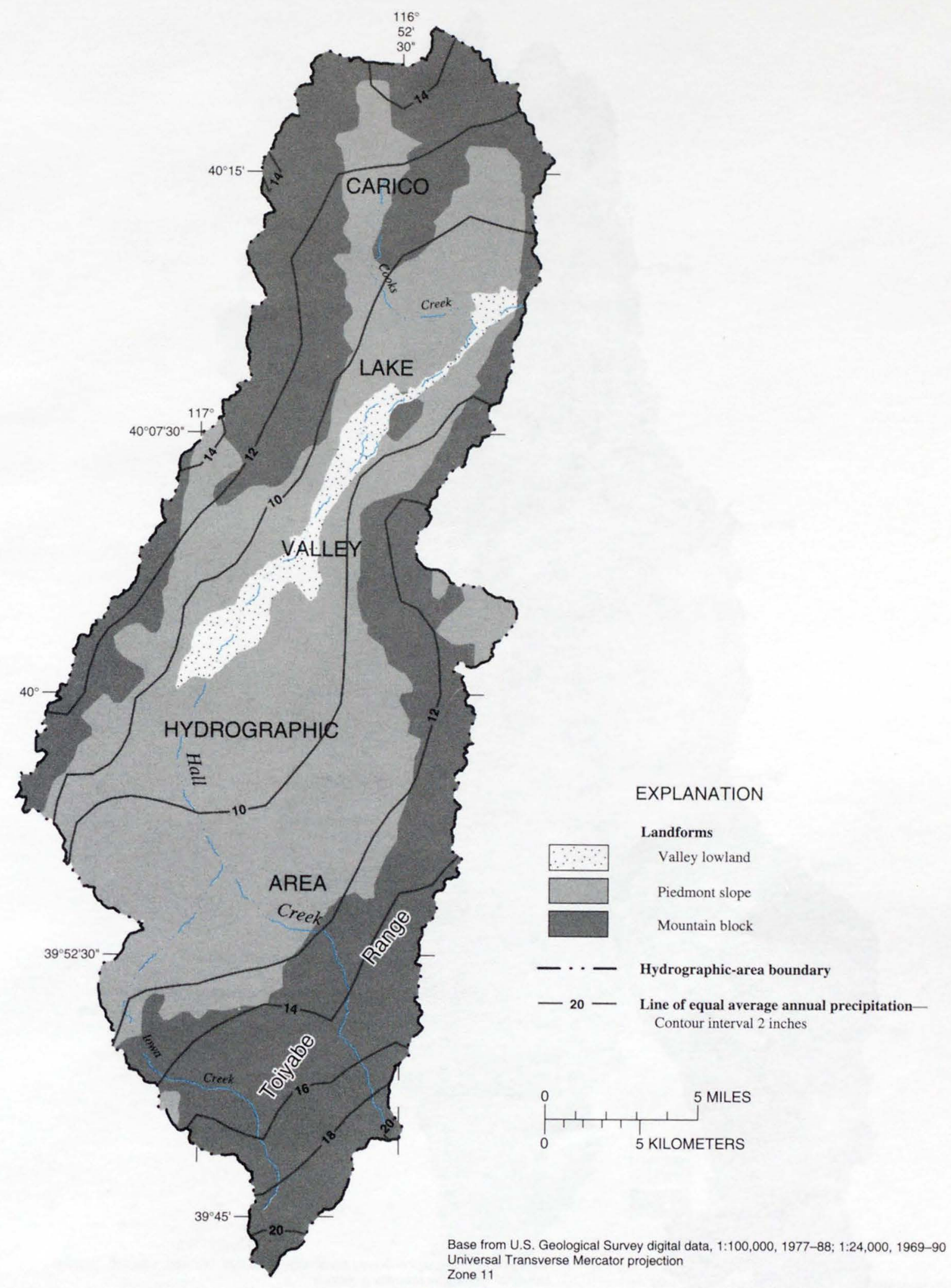

Figure 6. Distribution of precipitation (1961-90) and landforms in Carico Lake Valley Hydrographic Area, middle Humboldt River Basin, north-central Nevada. Average annual-precipitation data derived from precipitationelevation regressions on independent slopes model, or PRISM (Daly and others, 1994). 


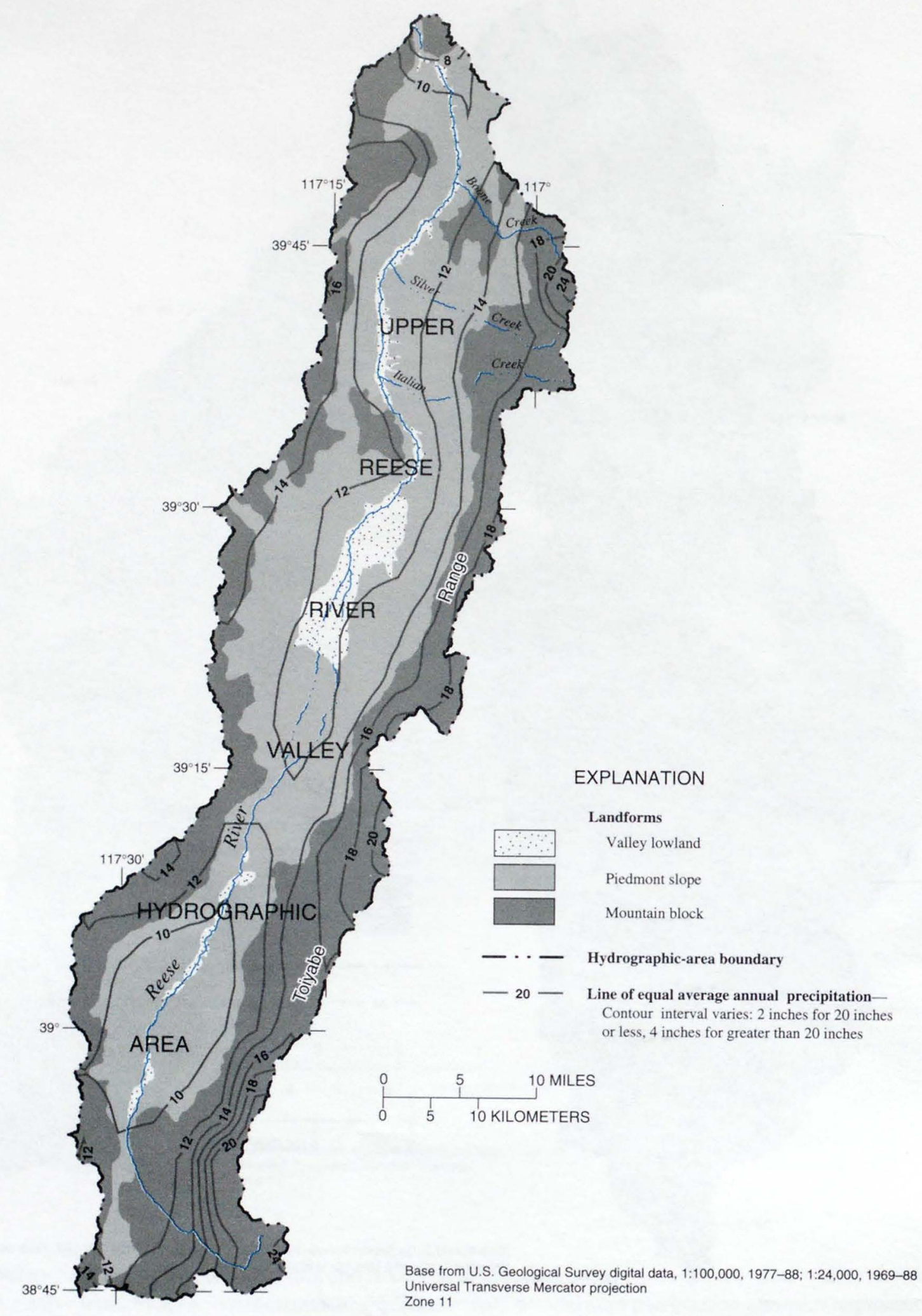

Figure 7. Distribution of precipitation (1961-90) and landforms in Upper Reese River Valley Hydrographic Area, middle Humboldt River Basin, north-central Nevada. Average annual-precipitation data derived from precipitation-elevation regressions on independent slopes model, or PRISM (Daly and others, 1994). 


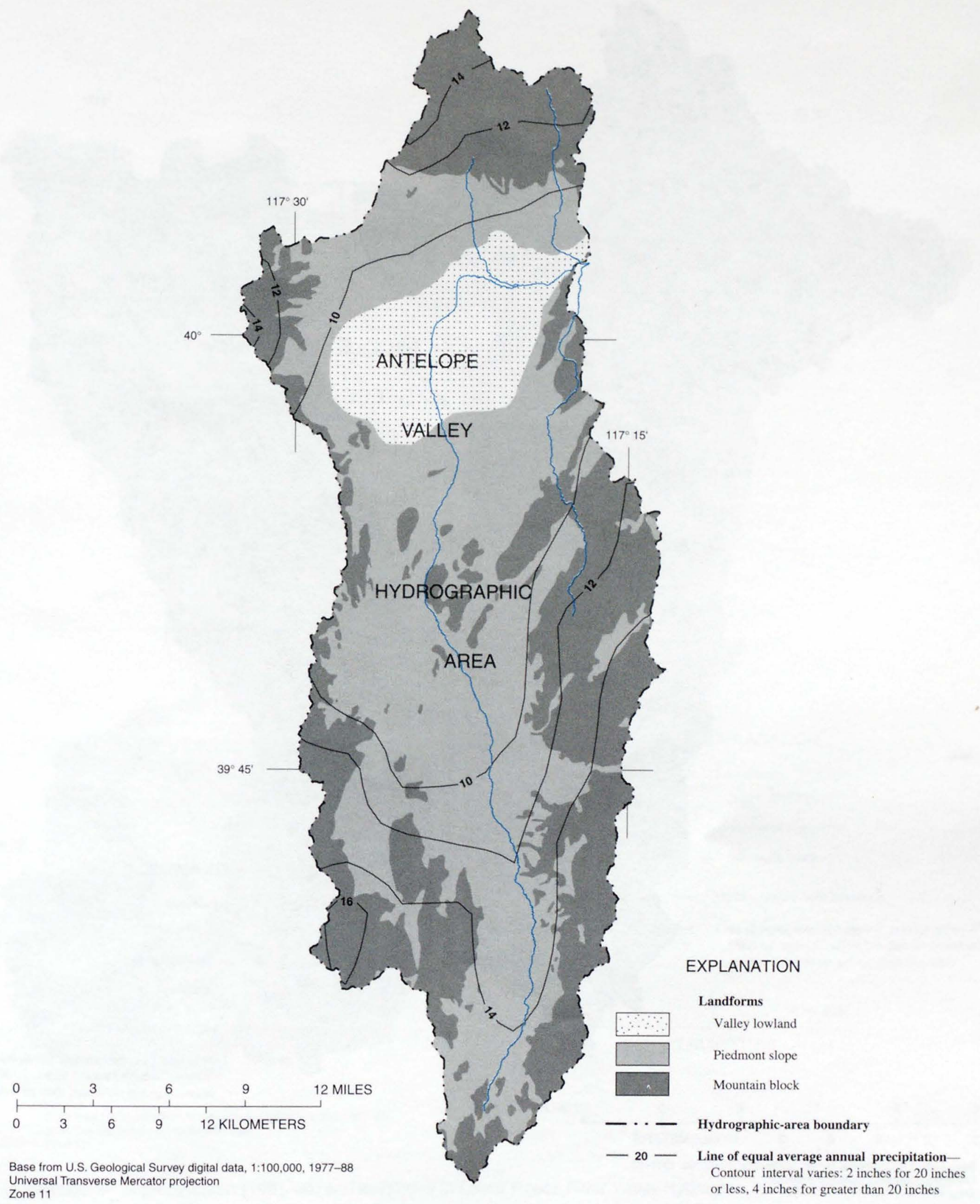

Figure 8. Distribution of precipitation (1961-90) and landforms in Antelope Valley Hydrographic Area, middle Humboldt River Basin, north-central Nevada. Average annual-precipitation data derived from precipitation-elevation regressions on independent slopes model, or PRISM (Daly and others, 1994). 


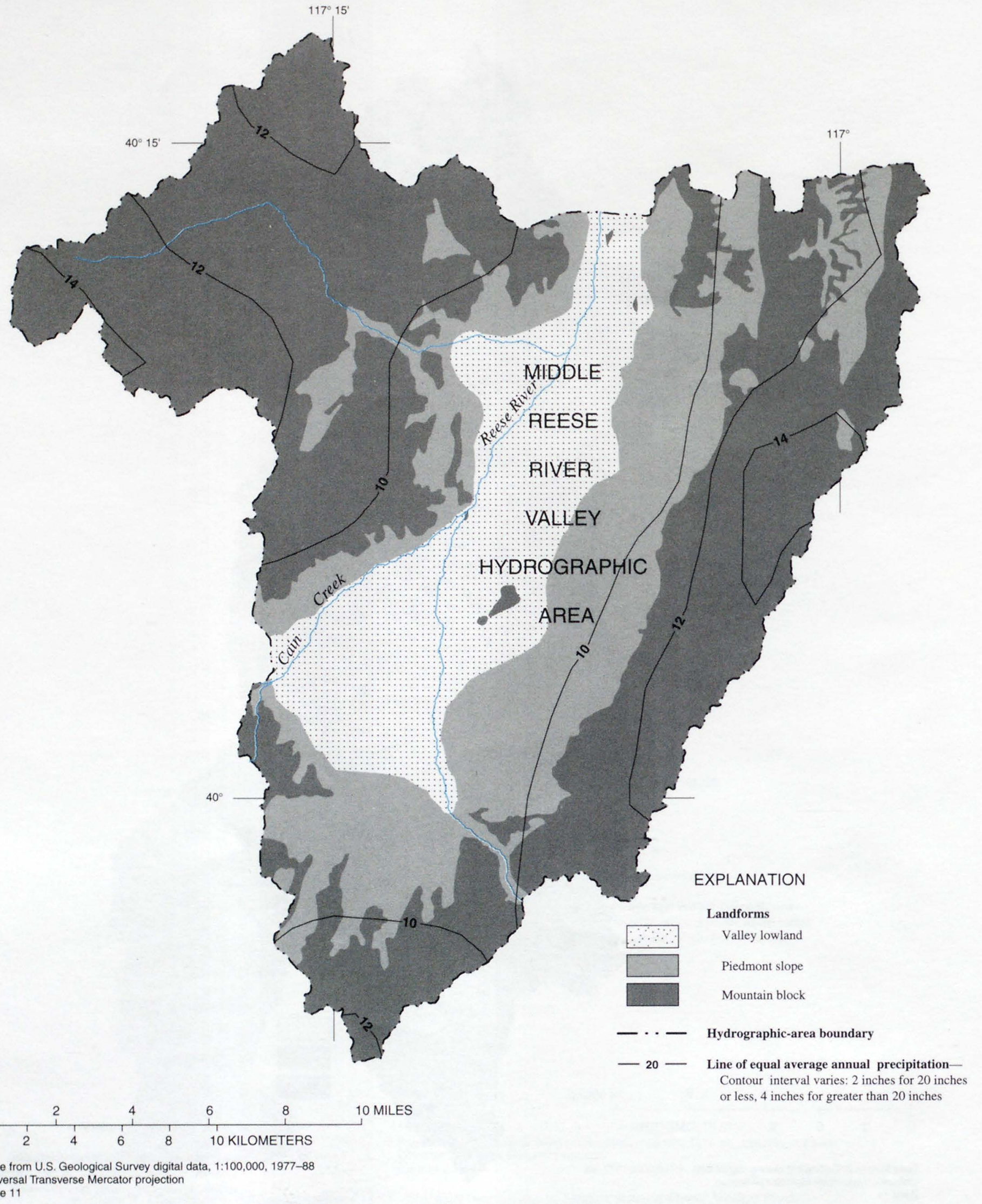

Figure 9. Distribution of precipitation (1961-90) and landforms in Middle Reese River Valley Hydrographic Area, middle Humboldt River Basin, north-central Nevada. Average annual-precipitation data derived from precipitation-elevation regressions on indepedent slopes model, or PRISM (Daly and others, 1994). 


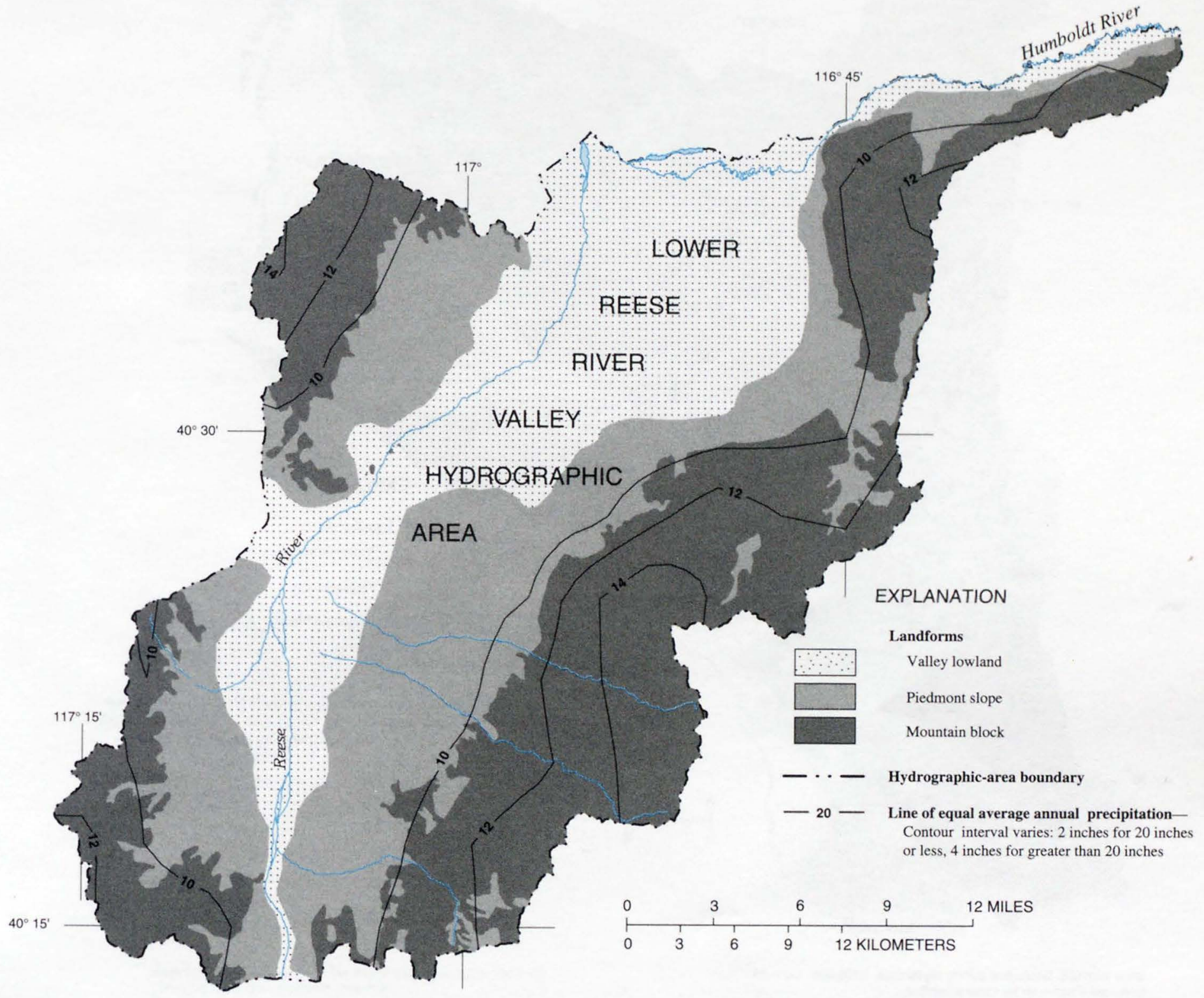

Base from U.S. Geological Survey digital data, 1:100,000, 1977-88 Universal Transverse Mercator projection Zone 11

Figure 10. Distribution of precipitation (1961-90) and landforms in Lower Reese River Valley Hydrographic Area, middle Humboldt River Basin, north-central Nevada. Average annual-precipitation data derived from precipitation-elevation regressions on independent slopes model, or PRISM (Daly and others, 1994). 


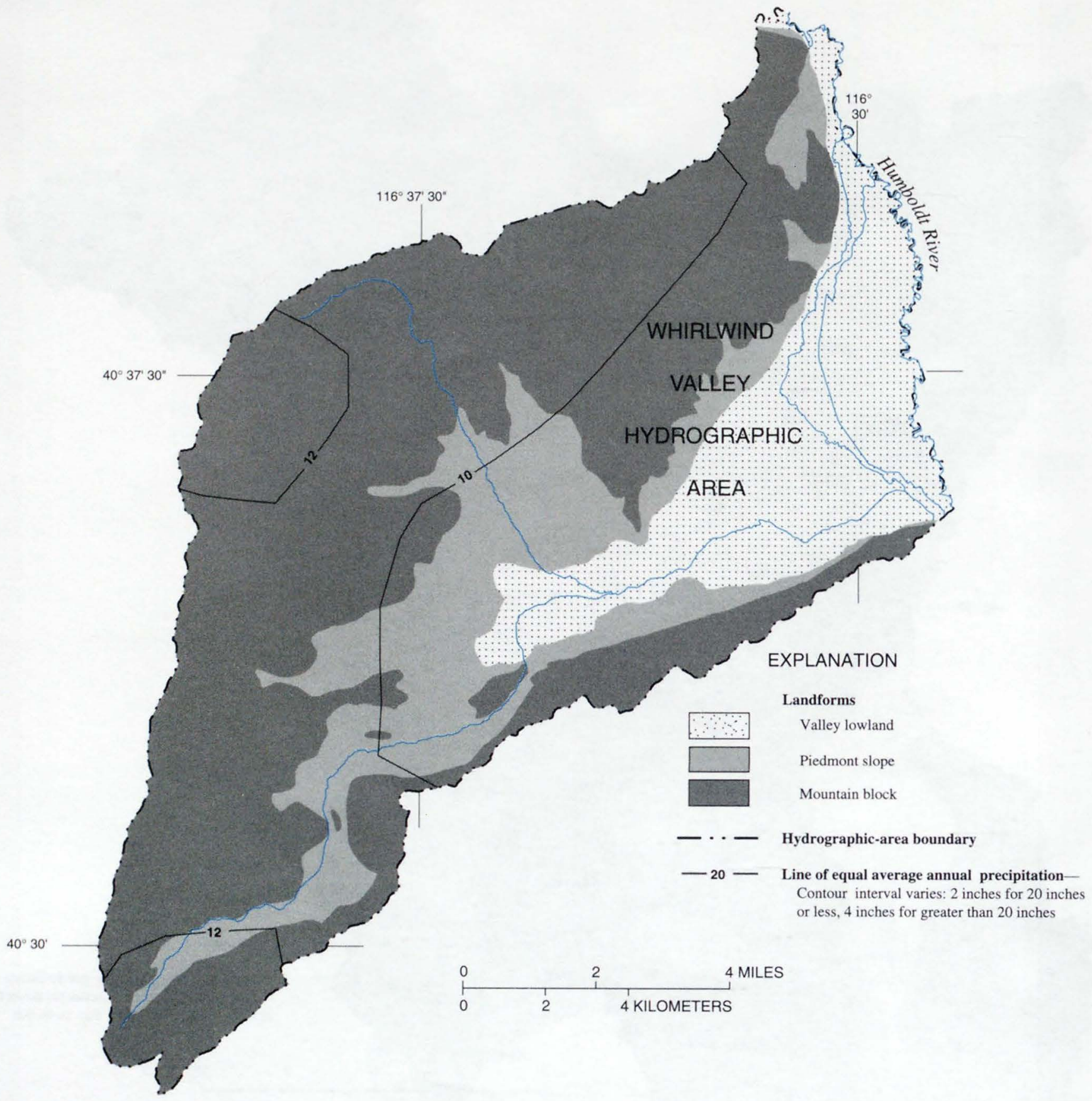

Base from U.S. Geological Survey digital data, 1:100,000, 1977-88 Universal Transverse Mercator projection

Zone 11

Figure 11. Distribution of precipitation (1961-90) and landforms in Whirlwind Valley Hydrographic Area, middle Humboldt River Basin, north-central Nevada. Average annual-precipitation data derived from precipitation-elevation regressions on independent slopes model, or PRISM (Daly and others, 1994). 


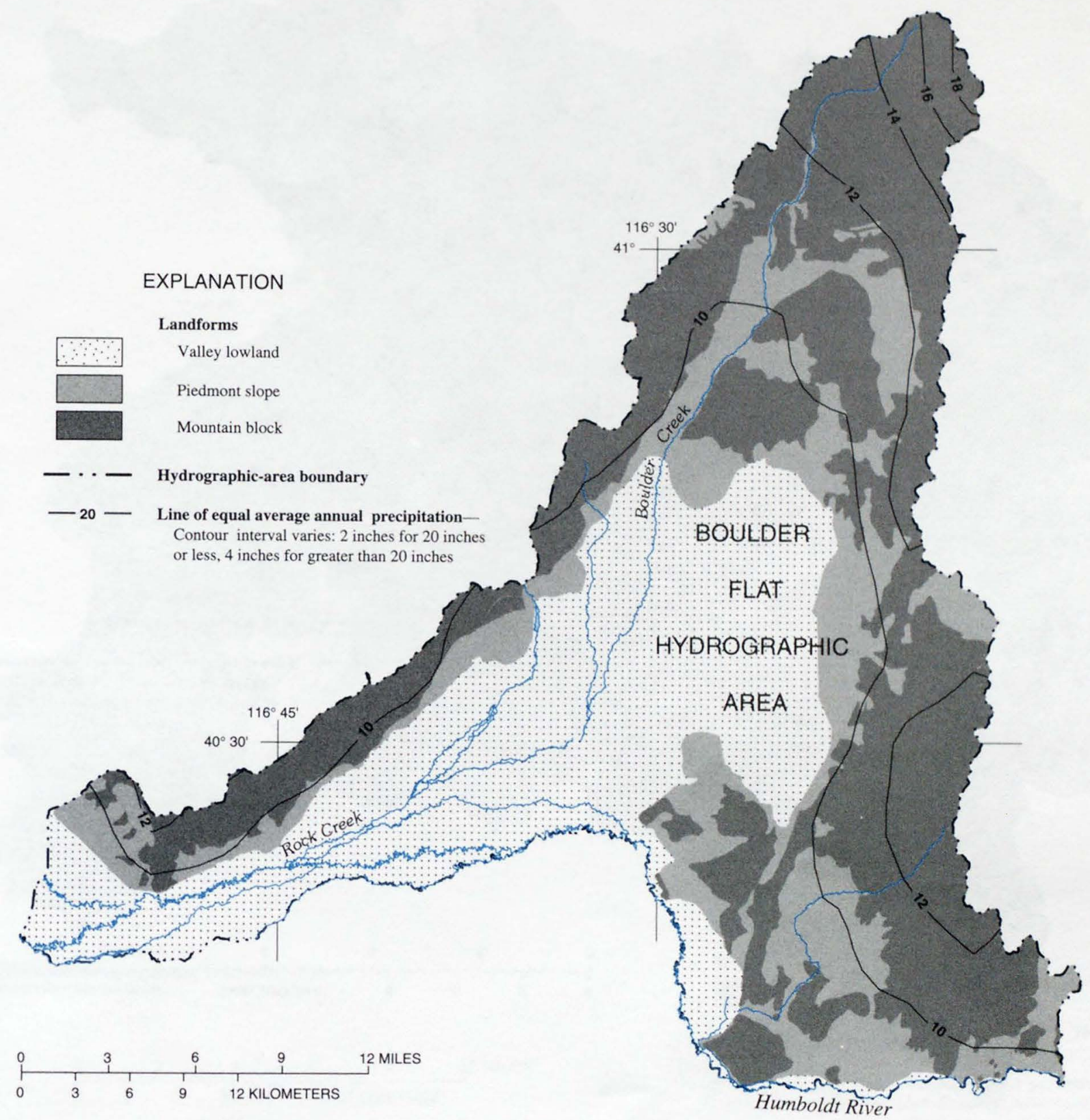

Base from U.S. Geological Survey digital data, 1:100,000, 1977-88 Universal Transverse Mercator projection

Zone 11

Figure 12. Distribution of precipitation (1961-90) and landforms in Boulder Flat Hydrographic Area, middle Humboldt River Basin, north-central Nevada. Average annual-precipitation data derived from precipitation-elevation regressions on independent slopes model, or PRISM (Daly and others, 1994). 


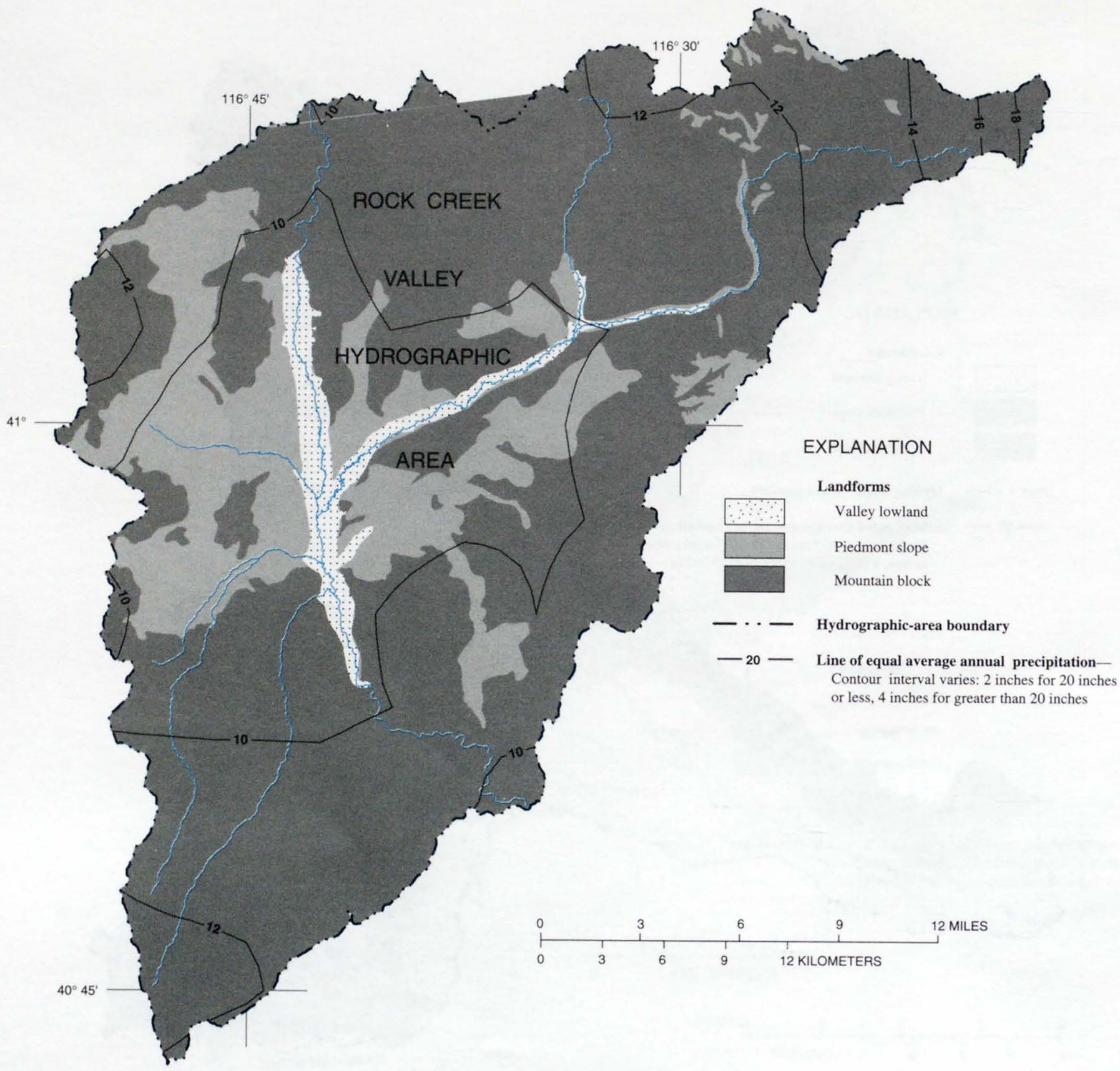

Base from U.S. Geological Survey digital data, 1:100,000, 1977-88 Universal Transverse Mercator projection Zone 11

Figure 13. Distribution of precipitation (1961-90) and landforms in Rock Creek Hydrographic Area, middle Humboldt River Basin, north-central Nevada. Average annual-precipitation data derived from precipitation-elevation regressions on independent slopes model, or PRISM (Daly and others, 1994). 


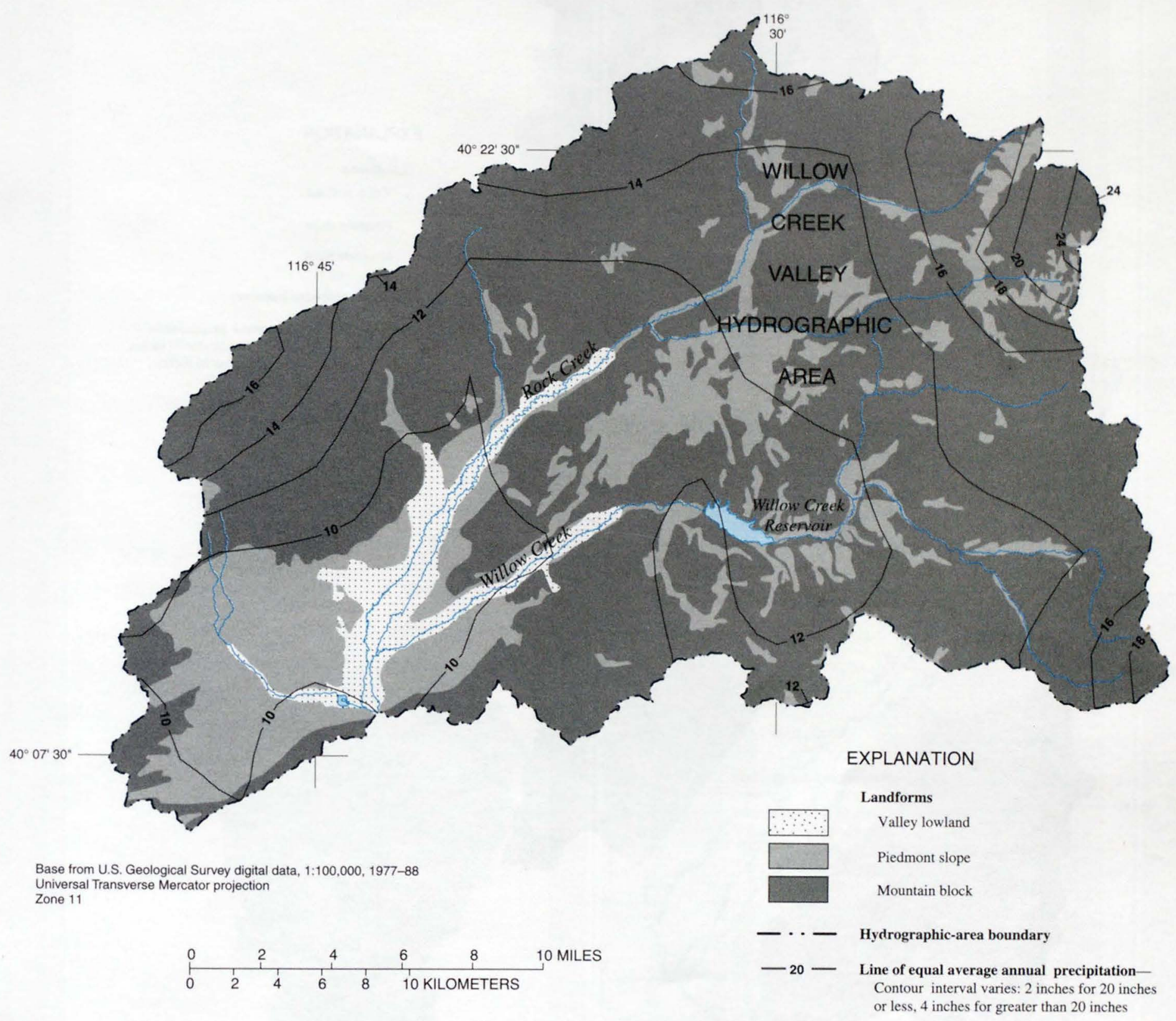

Figure 14. Distribution of precipitation (1961-90) and landforms in Willow Creek Valley Hydrographic Area, middle Humboldt River Basin, north-central Nevada. Average annual-precipitation data derived from precipitation-elevation regressions on independent slopes model, or PRISM (Daly and others, 1994). 


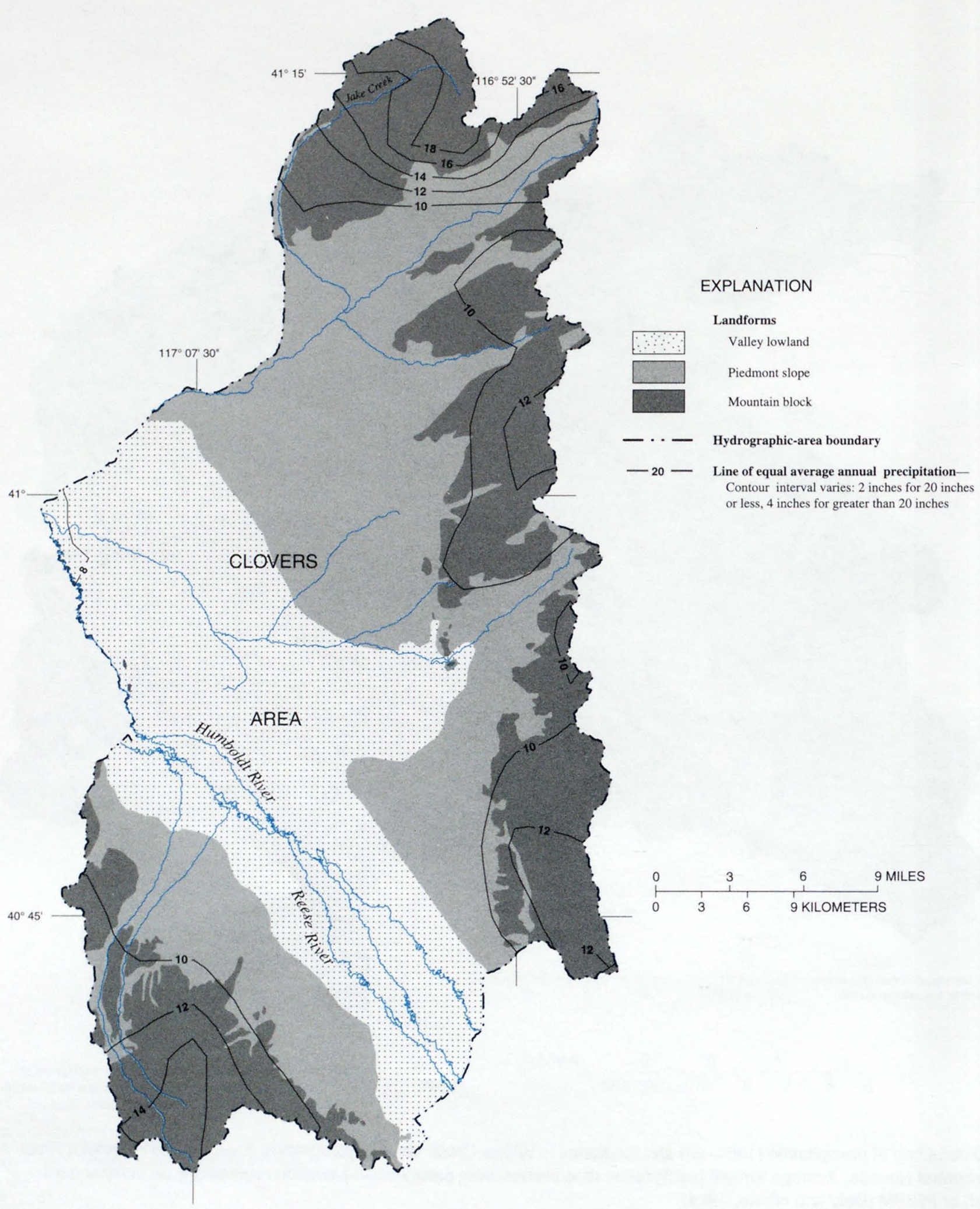

Base from U.S. Geological Survey digital data, 1:100,000, 1977-88 Universal Transverse Mercator projection

Zone 11

Figure 15. Distribution of precipitation (1961-90) and landforms in Clovers Area Hydrographic Area, middle Humboldt River Basin, north-central Nevada. Average annual-precipitation data derived from precipitation-elevation regressions on independent slopes model, or PRISM (Daly and others, 1994). 


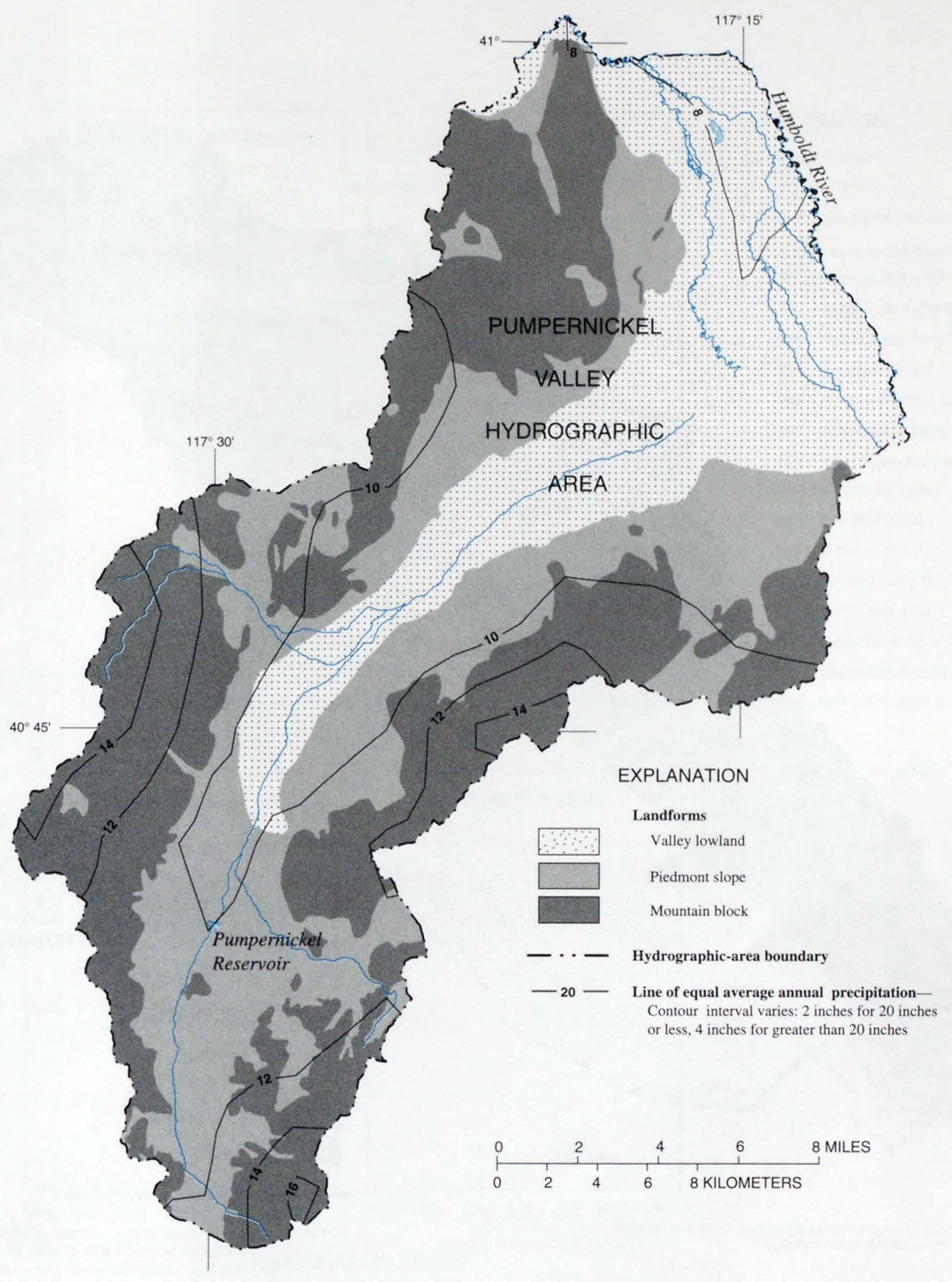

Base from U.S. Geological Survey digital data, 1:100,000, 1977-88 Universal Transverse Mercator projection Zone 11

Figure 16. Distribution of precipitation (1961-90) and landforms in Pumpernickel Valley Hydrographic Area, middle Humboldt River Basin, north-central Nevada. Average annual-precipitation data derived from precipitation-elevation regressions on independent slopes model, or PRISM (Daly and others, 1994). 


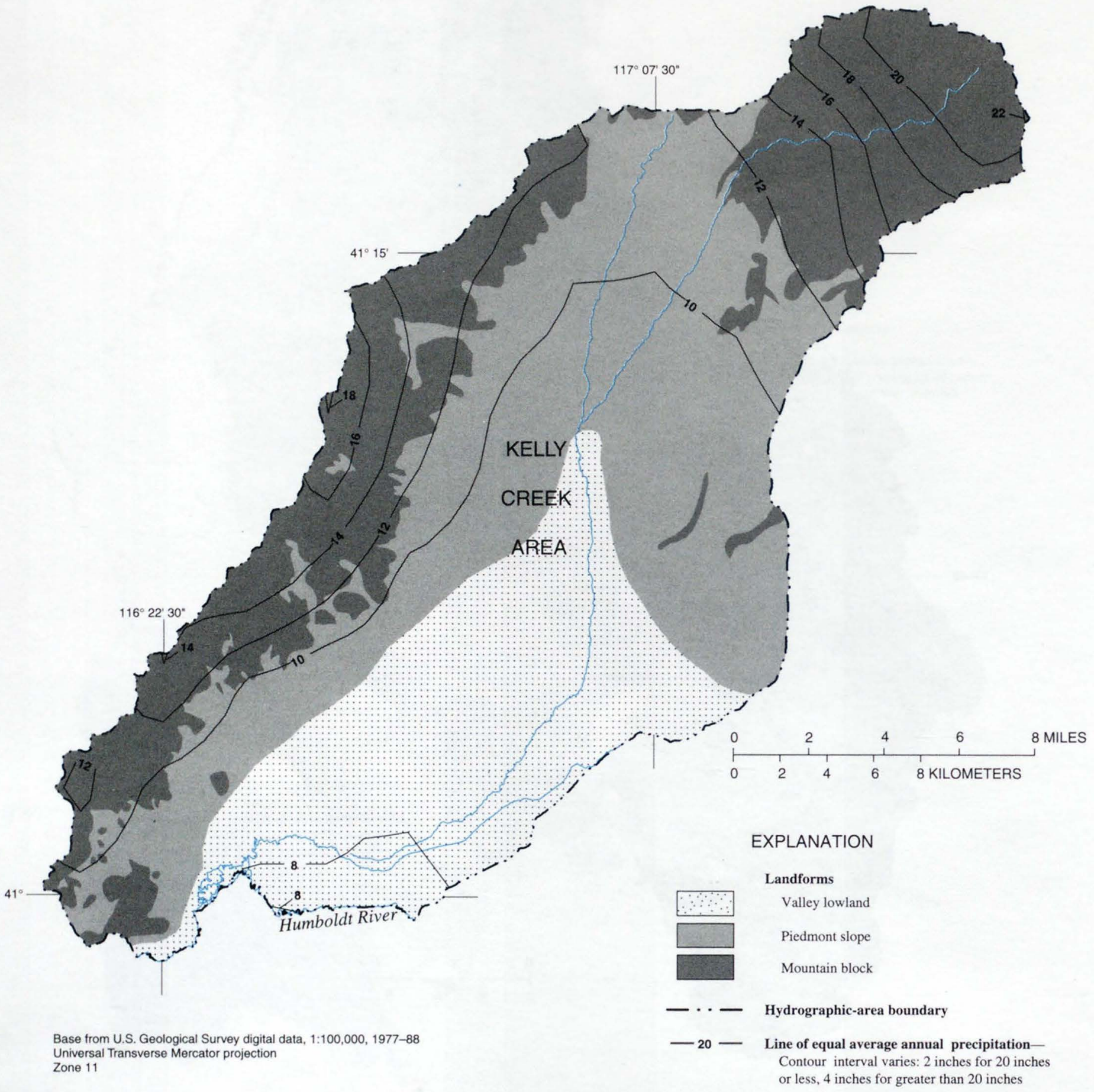

Figure 17. Distribution of precipitation (1961-90) and landforms in Kelly Creek Area Hydrographic Area, middle Humboldt River Basin, north-central Nevada. Average annual-precipitation data derived from precipitation-elevation regressions on independent slopes model, or PRISM (Daly and others, 1994). 


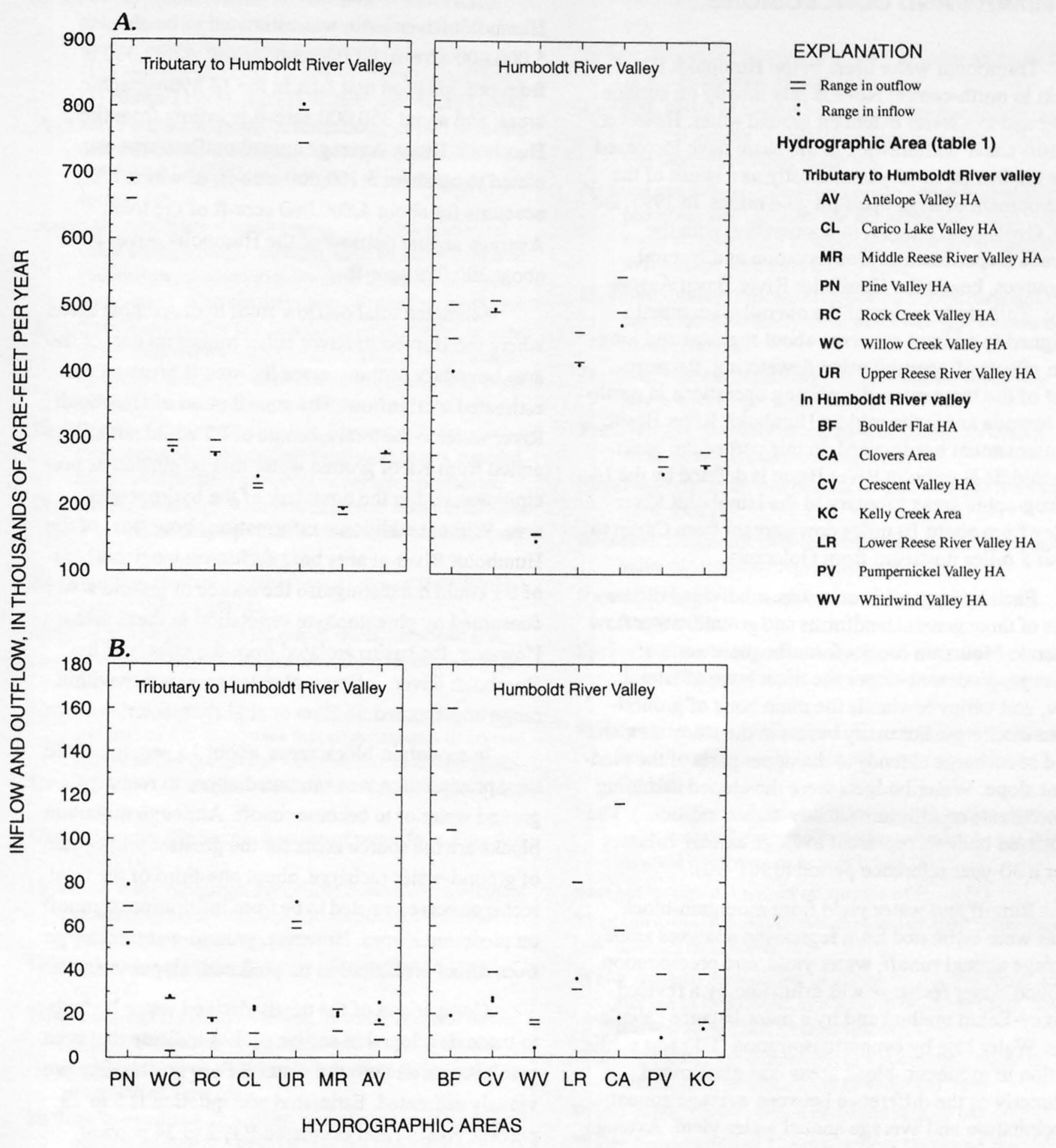

Figure 18. Estimated inflow and outflow for 14 hydrographic areas in middle Humboldt River Basin, north-central Nevada. $A$, Total water budget. $B$, Ground-water budget. 
SUMMARY AND CONCLUSIONS

Traditional water users in the Humboldt River Basin in north-central Nevada rely mostly on surface water and to a lesser extent on ground water. However, ground-water withdrawals in the basin have increased over the last 10 to 15 years, mostly as a result of the development of large open-pit gold mines. In 1995, the U.S. Geological Survey, in cooperation with the Nevada Department of Conservation and Natural Resources, began the Humboldt River Basin Assessment. This study is part of the overall assessment designed to address concerns about regional and longterm effects of open-pit mine dewatering. Because most of the large mine-dewatering operations in northern Nevada are in the middle Humboldt River Basin, the assessment has focused on this part of the basin. The middle Humboldt River Basin is defined by the 14 hydrographic areas tributary to the Humboldt River valley from about 10 miles downstream from Carlin to about 5 miles upstream from Golconda.

Each hydrographic area was subdivided on the basis of three general landforms and ground-water flow patterns. Mountain blocks form the main zone of recharge, piedmont slopes the main zone of lateral flow, and valley lowlands the main zone of groundwater discharge. For many basins in the study area, the zone of recharge extends to the upper parts of the piedmont slope. Water budgets were developed assuming approximate equilibrium (steady-state conditions). The estimated budgets represent average annual volumes over a 30-year reference period (1961-90).

Runoff and water yield from mountain-block areas were estimated from regression analyses among average annual runoff, water yield, and precipitation. Ground-water recharge was estimated by a revised Maxey-Eakin method and by a mass-balance calculation. Water loss by evapotranspiration (ET) and sublimation in mountain-block areas was determined indirectly as the difference between average annual precipitation and average annual water yield. Average annual ET from piedmont slopes was derived, in part, by the Penman-Monteith equation using weather-station data. Ground-water ET in valley-lowland areas was estimated from a recently developed method using micrometeorological techniques and remotely sensed Landsat Thematic Mapper (satellite) data.
On average, total annual inflow to the middle Humboldt River basin was estimated to be about $5,000,000$ acre-ft. Of the total inflow, $4,600,000$ is from precipitation that falls in the 14 hydrographic areas, and about 350,000 acre-ft is inflow from the Humboldt River. Average annual outflow was estimated to be about 5,100,000 acre-ft, of which ET accounts for about 4,800,000 acre-ft of the total. Average annual outflow of the Humboldt River is about 300,000 acre-ft.

Estimated total outflow from hydrographic areas where the Humboldt River either makes up part of the area boundary or transverses the area is greater than estimated total inflow. The contribution of Humboldt River water to the total estimate of ET could not be separated from ET of ground water that originated as precipitation within the boundary of the hydrographic area. Without additional information about flow of the Humboldt River at area boundaries, regional analysis of ET could not distinguish the source of ground water consumed by phreatophyte vegetation in these areas. However, for basins isolated from the effects of the Humboldt River, inflow estimates were either within range of estimated outflow or slightly greater.

In mountain-block areas, about 15 percent of the total precipitation was estimated either to recharge ground water or to become runoff. Although mountain blocks are the source areas for the greatest proportion of ground-water recharge, about one-third of the total recharge was estimated to be from infiltration of runoff on piedmont slopes. However, ground-water recharge from direct precipitation on piedmont slopes is small.

Comparison of the newly derived water budgets to those developed in earlier studies indicate that both precipitation and ground-water ET are greater than previously estimated. Estimated precipitation is 5 to 28 percent greater, and estimated ET, 2 to 34 percent greater, although the proportion of the annual precipitation assumed to be lost to ET is similar in the current and earlier studies. Based on current mass-balance calculations, estimates of ground-water recharge are about 45 percent greater than previously estimated. 


\section{GLOSSARY}

Some of the technical terms and acronyms used in this report are defined for the convenience of the reader. Most of the following definitions were modified from

(1) Langbein and Iseri (1960), (2) Tomlinson (1994),

(3) Horton (1998), and (4) Wilson and Moore (1998).

Aquifer. Formation, group of formations, or part of formation that contains sufficient saturated permeable material to yield significant quantities of water to wells and springs (4).

Average conditions. Conditions under which numerical value for hydrologic variable, such as precipitation or streamflow, is equal to arithmetic mean for selected time period. Also see definition of "natural conditions."

Baseflow. Sustained or fair-weather flow of stream, whether or not affected by works of man. That part of stream discharge that is not attributable to direct runoff from precipitation or melting snow (4).

Coefficient of determination $\left(r^{2}\right)$. Measure of proportion of total variance of dependent variable that is accounted for by independent variables in regression analyses.

Dewatering (mining). Removal of ground water in conjunction with mining operations when excavation has penetrated below water table (3).

Evaporation. Process by which water passes from liquid state to vapor state (4).

Evapotranspiration (ET). Loss of water from land area through transpiration by plants and evaporation from soil and surface-water bodies (4).

Geographic information system (GIS). Computer program and associated data bases that organize data in layers which can be integrated, queried, and analyzed $(3,4)$.

Ground water. That part of subsurface water that is in saturated zone (4).

Ground-water discharge. Release of water from saturated zone (4).

Ground-water recharge. Process of downward movement of water to saturated zone and addition of water to ground-water reservoir (4).

Ground-water storage. Quantity of water in saturated zone (4).

Hydraulic conductivity. Volume of water that will move in porous medium in unit time under unit hydraulic gradient through unit area measured at right angles to direction of flow (4).

Hydraulic gradient. In aquifer, rate of change of total head per unit of distance of flow at given point and in given direction (4).

Hydrologic equilibrium. Expression of law of mass conservation for water budgets. State in which inflow equals outflow, corrected for changes in storage.

Hydrologic processes. Physical operation or series of operations that result in movement of water within hydrologic system.
Hydrologic system. Complex of related parts-physical, conceptual, or both - forming orderly working body of hydrologic units and interacting hydrologic processes (4).

Inflow. Process of flowing in or into; includes all water that enters hydrologic system (4).

Landsat. Series of United States satellites that collect multispectral images of Earth's surface in visible, reflected, and thermal-infrared bands (4).

Natural conditions. Conditions under which hydrologic processes and variables are not affected by man. For water budgets, such conditions commonly are assumed to represent long-term steady state.

Open-pit mining. Process of removing mineral deposits that are found sufficiently close to surface that tunnels are unnecessary.

Outflow. Process of flowing out; includes all water that leaves hydrologic system (4).

Permeability. Property or capacity of porous rock, sediment, or soil for transmitting water (4).

Phreatophyte. Plant that obtains its water supply from saturated zone (4).

Residual. Difference between measured station value and value predicted by regression equation.

Runoff. That part of precipitation appearing in surface streams (4).

Spring. Place where ground water flows naturally from rock or soil onto land surface or into body of surface water (4).

Steady state. State of balance in hydrologic system where little or no change in hydraulic head occurs through time (4).

Streamflow. Type of channel flow; applies to that part of surface runoff traveling in stream whether or not it is affected by diversion or regulation (4).

Surface water. All waters on surface of Earth (1).

Transpiration. Process by which plants give off water vapor through their leaves (4).

Water budget. Accounting of inflow to, outflow from, and storage in hydrologic unit such as drainage basin, aquifer, soil zone, lake, or reservoir (4).

Watershed. Region drained by, or contributing water to, stream, lake, or other body of water (4).

Water table. Upper surface of saturated zone (4).

Water year. Period of 12 months from October 1 through September 30 ; term used by federal agencies in reference to surface-water supply (4).

Water yield. Runoff from drainage basin; includes groundwater outflow that appears in stream plus ground-water outflow that bypasses gaging station and leaves basin underground. May be expressed as precipitation minus evapotranspiration $(4,1)$. 


\section{REFERENCES CITED}

Berger, D.L., 2000, Water budgets for Pine Valley, Carico Lake Valley, and Upper Reese River Valley Hydrographic Areas, middle Humboldt River Basin, northcentral Nevada-Methods for estimation and results: U.S. Geological Survey Water-Resources Investigation Report, 99-4272, 40 p.

Cardinalli, J.L., Roach, L.M., Rush, F.E., and Vasey, B.J., 1968, State of Nevada hydrographic areas: Nevada Division of Water Resources map, scale 1:500,000.

Crosthwaite, E.G., 1963, Ground-water appraisal of Antelope and Middle Reese River Valleys, Lander County, Nevada: Nevada Department of Conservation and Natural Resources, Ground-Water Resources-Reconnaissance Report 19, 33 p.

Daly, Christopher, Neilson, R.P., and Phillips, D.L., 1994, A statistical-topographic model for mapping climatological precipitation over mountainous terrain: Journal of Applied Meteorology, v. 33, no. 2, p. 140-158.

Dettinger, M.D., and Schaefer, D.H., 1995, Decade-scale hydroclimatic forcing of ground-water levels in the central Great Basin, Eastern Nevada: Water Resources and Environmental Hazards: Emphasis on Hydrologic and Cultural Insight in the Pacific Rim, American Water Resources Association, June, 1995, pp. 195-204.

Eakin, T.E., 1961, Ground-water appraisal of Pine Valley, Eureka and Elko Counties, Nevada: Nevada Department of Conservation and Natural Resources, GroundWater Resources-Reconnaissance Report 2, 41 p.

Eakin, T.E., and Lamke, R.D., 1966, Hydrologic reconnaissance of the Humboldt River Basin, Nevada, with a section on Quality of water, by D.E. Everett: Nevada Department of Conservation and Natural Resources, Water Resources Bulletin 32, $107 \mathrm{p}$.

Eakin, T.E., Maxey, G.B., Robinson, T.W., Fredericks, J.C., and Loeltz, O.J., 1951, Contributions to the hydrology of eastern Nevada: Nevada State Engineer, Water Resources Bulletin 12, $171 \mathrm{p}$.

Eakin, T.E., Moore, D.O., and Everett, D.E., 1965, Waterresources appraisal of the Upper Reese River Valley, Lander and Nye Counties, Nevada: Nevada Department of Conservation and Natural Resources, Water Resources-Reconnaissance Report 31, 47 p.

Everett, D.E., and Rush, F.E., 1966, A brief appraisal of the water resources of Grass and Carico Lake Valleys, Lander and Eureka Counties, Nevada: Nevada Department of Conservation and Natural Resources, Water Resources-Reconnaissance Report 37, 27 p.

Hardman, George, and Mason, H.G., 1949, Irrigated lands in Nevada: University of Nevada, Reno, Agricultural Experiment Station Bulletin 183, 57 p.
Harrill, J.R., 1968, Hydrologic response to irrigation pumping in Diamond Valley, Eureka and Elko Counties, Nevada, 1950-65: Nevada Department of Conservation and Natural Resources, Water Resources Bulletin 35, $85 \mathrm{p}$.

Heath, R.C., 1989, Basic ground-water hydrology: U.S. Geological Survey Water-Supply Paper 2220, 84 p.

Hess, R.H., and Johnson, G.L., 1997, County digital geologic maps [CD-ROM]: Reno, Nevada Bureau of Mines and Geology Open-File Report 97-1.

Horton, G.A., 1998, Water words dictionary, Pt. 1, A compilation of technical water, water quality, environmental, and water-related terms (8th ed.): Nevada Division of Water Planning, 385 p. (accessed May 7, 1999, on World Wide Web at URL $<$ http://www.state.nv.us/ndwp/dict-1/ww-index.html>.

Langbein, W.B., and Iseri, K.T., 1960, Manual of hydrology, Pt. 1, General surface-water techniques - General introduction and hydrologic definitions: U.S. Geological Survey Water-Supply Paper 1541-A, 29 p.

Maurer, D.K., Plume, R.W., Thomas, J.M., and Johnson, A. K., 1996, Water resources and effects of changes in ground-water use along the Carlin Trend, north-central Nevada: U.S. Geological Survey Water-Resources Investigations Report, 96-4134, $146 \mathrm{p}$.

Maurer, D.K., and Berger, D.L., 1997, Subsurface flow and water yield from watersheds tributary to Eagle Valley Hydrographic Area, west-central Nevada: U.S. Geological Survey Water-Resources Investigations Report 97-4191, 56 p.

Maxey, G.B., and Eakin, T.E., 1949, Ground water in White River Valley, White Pine, Nye, and Lincoln Counties, Nevada: Nevada State Engineer, Water Resources Bulletin $8,53 \mathrm{p}$.

Monteith, J.L., 1965, Evaporation and environment, the state and movement of water in living organisms, in G.E. Fogg, ed., Proceedings, Symposium No. 19, Society for Experimental Biology: New York, Academic Press, p. 205-234.

Nichols, W.D., 2000, Regional ground-water evapotranspiration and ground-water budgets, Great Basin, Nevada: U.S. Geological Survey Professional Paper 1628, 82 p.

Olmsted, F.H., and Rush, F.E., 1987, Hydrogeologic reconnaissance of the Beowawe geysers geothermal area, Nevada: Geothermics, vol. 16, no. 1, p. 27-46.

Owenby, J.H., and Ezell, D.S., 1992, Monthly station normals of temperature, precipitation, and heating and cooling degree days, 1961-90, Nevada: National Climatic Data Center, National Oceanic and Atmospheric Administration, Climatography of the United States no. $81,[20] \mathrm{p}$.

Peterson, FF., 1981, Landforms of the Basin and Range Province: University of Nevada, Reno, Agricultural Experiment Station, Technical Bulletin 28, $52 \mathrm{p}$. 
Plume, R.W., 1996, Hydrogeologic framework of the Great Basin region of Nevada, Utah, and adjacent States: U.S. Geological Survey Professional Paper, 1409-B, 64 p.

Plume, R.W., and Carlton, S.M., 1988, Hydrogeology of the Great Basin region of Nevada, Utah, and adjacent States: U.S. Geological Survey Hydrologic Investigations Atlas, HA-694-A, 1 sheet, scale 1:1,000,000.

Plume, R.W., and Ponce, D.A., 1999, Hydrogeologic framework and ground-water levels, 1982 and 1996, middle Humboldt River Basin, north-central Nevada: U.S. Geological Survey Water-Resources Investigation Report 98-4209, 2 sheets.

Rorabaugh, M.I., 1964, Estimating changes in bank storage and ground-water contribution to streamflow: International Association of Scientific Hydrology Publication 63 , p. 432-441.

Rush, F.E., 1968, Index of hydrographic areas in Nevada: Nevada Division of Water Resources, Information Report 6, $38 \mathrm{p}$.

Rush, F.E., Scott, B.R., Van Denburgh, A.S., and Vasey, B.J., 1971, Water resources and inter-basin flow: Nevada Division of Water Resources, 1 sheet, scale 1:750,000.
Shevenell, Lisa, 1996, Statewide potential evapotranspiration maps for Nevada: Nevada Bureau of Mines and Geology report 48, 32 p.

Tomlinson, S.A., 1994, Instrumentation methods and preliminary evaluation of evapotranspiration for a grassland in the Arid Lands Ecology Reserve, Benton County, Washington, May-October 1990: U.S. Geological Survey Water-Resources Investigations Report 93-4081, $32 \mathrm{p}$.

U.S. Geological Survey, 1986, U.S. GeoData land-use and land-cover digital data from 1:250,000- and 1:100,000scale maps-Data users guide 4: U.S. Geological Survey National Mapping Program Technical Instructions, $36 \mathrm{p}$.

1987, U.S. GeoData digital elevation models - Data users guide 5: U.S. Geological Survey National Mapping Program Technical Instructions, $38 \mathrm{p}$.

Wilson, W.E., and Moore, J.E., eds., 1998, Glossary of hydrology: Alexandria, Va., American Geological Institute, $248 \mathrm{p}$.

Zones, CP., 1961, Ground-water potentialities in the Crescent Valley, Eureka and Lander Counties, Nevada: U.S. Geological Survey Water-Supply Paper $1581,50 \mathrm{p}$. 


\section{science for a changing world}

Since 1879, the U.S. Geological Survey has been providing maps, reports, and information to help others who manage, develop, and protect our Nation's water, energy, mineral, land, and biological resources. We help find natural resources, and we supply scientific understanding needed to help minimize or mitigate the effects of natural hazards and the environmental damage caused by human activities. The results of our efforts touch the daily lives of almost everyone. 